Rômulo Loureiro Casciano

A profissionalidade docente de professores iniciantes: um estudo com licenciados em Pedagogia e em Biologia

Dissertação de Mestrado

Dissertação apresentada ao Programa de PósGraduação em Educação da PUC-Rio como requisito parcial para obtenção do título de Mestre em Educação.

Orientadora: Prof. ${ }^{\text {a }}$ Rosaly Hermengarda Lima Brandão 


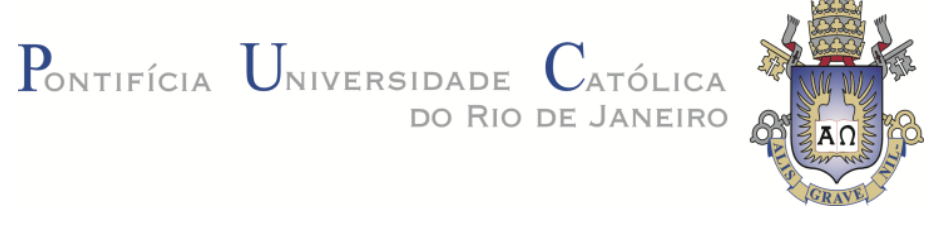

Rômulo Loureiro Casciano

\title{
A profissionalidade docente de professores iniciantes: um estudo com licenciados em Pedagogia e em Biologia
}

\begin{abstract}
Dissertação apresentada como requisito parcial para obtenção do grau de Mestre pelo Programa de PósGraduação em Educação da PUC-Rio.
\end{abstract}

Profa. Rosaly Hermengarda Lima Brandão

Orientadora

Departamento de Educação - PUC-Rio

Profa. Isabel Alice Oswald Monteiro Lelis

Departamento de Educação - PUC-Rio

Profa. Flávia Medeiros Sarti Departamento de Educação - UNESP

Prof ${ }^{a}$ Denise Berruezo Portinari

Coordenadora Setorial do Centro

de Teologia e Ciências Humanas - PUC-Rio

Rio de Janeiro, 31 de março de 2016. 
Todos os direitos reservados. É proibida a reprodução total ou parcial do trabalho sem autorização da universidade, da autora e do orientador.

\section{Rômulo Loureiro Casciano}

Concluiu o curso de Licenciatura em Ciências Biológicas pela Universidade Federal do Rio de Janeiro em 2009. Professor de Ciências na rede municipal de Cabo Frio/RJ desde 2010. Participa do Grupo de Pesquisas em Sociologia da Educação (SOCED/PUC-Rio).

Ficha Catalográfica

Casciano, Rômulo Loureiro

A profissionalidade docente de professores iniciantes: um estudo com licenciados em Pedagogia e em Biologia / Rômulo Loureiro Casciano ; orientadora: Rosaly Hermengarda Lima Brandão. - 2016.

142 f. : il.(color.) ; $30 \mathrm{~cm}$

Dissertação (mestrado)-Pontifícia Universidade Católica do Rio de Janeiro, Departamento de Educação, 2016.

Inclui bibliografia

1. Educação - Teses. 2. Professores iniciantes. 3. Profissionalidade. 4. Profissionalização. 5. Trabalho docente. I. Brandão, Zaia. II. Pontifícia Universidade Católica do Rio de Janeiro. Departamento de Educação. III. Título. 
A vocês alunas e alunos que iniciam os estudos e as descobertas e aos professores que estão aí do seu lado, torcendo e celebrando suas conquistas.

Somos todos eternos aprendizes. 


\section{Agradecimentos}

A Deus em sua infinita sabedoria, muito além de nossa compreensão, que nos deixa livres para trilhar o caminho da evolução e em sua infinita bondade por não nos deixar sozinhos em momento algum. Obrigado por fazer da vida um milagre que se perpetua diariamente e por enviar os melhores ajudantes para as lições mais difíceis.

Aos discentes, docentes e funcionários do Programa de Pós-Graduação em Educação da PUC-Rio por acolher e promover debates formativos-reflexivos e estimular o desenvolvimento de pesquisadores, professores e pessoas comprometidas com a educação brasileira. A importância da pesquisa deve ser ressaltada em sua continuidade, pluralidade e sociabilidade do conhecimento, a favor do desenvolvimento humano e da sociedade. Somos todos agentes de manutenção e mudança, que nossas ações, posturas e desejos sejam orientados pela justiça social e solidariedade.

Aos meus pais, Carlos e Denise, e aos meus irmãos, Vinícius e Vitor, pela coesão familiar em torno de valores como a gentileza, a humildade e a integridade. Entre nós há muita desavença e algum silêncio, relações estremecidas forjadas pelo amor e fraternidade, nas quais nunca faltou respeito e admiração mútuos. Dos fartos exemplos de perseverança aos incentivos para que cada um e todos possamos evoluir como cidadãos, indivíduos e espíritos, vocês são minhas 
referências e meu porto seguro. Obrigado por tolerarem manias, birras e mal humor, pelas risadas, bobagens, caronas, preocupações e por todas e cada uma das vezes que discordamos e tentamos nos entender. Obrigado por me fazer sentir acolhido, amado e estimulado a lutar por aquilo que acredito! Essa lição eu aprendo diariamente pelo convívio com vocês.

Viver a gratidão é um exercício diário: buscar nas provações a significação e a si mesmo, abraçar o drama e o afeto, chorar a tensão e a ternura, aconchegar-se na liberdade e na esperança, desculpar-se, estender a mão e abrir o coração. A gratidão não envolve metafísica ou teologia, ela é simples, poderosa e genial. Por essas e muitas que vejo a gratidão nas amizades, naqueles que nos oferecem tempo, presença e admiração, críticas, apoio e o inesperado. Portanto, agradeço aos amigos, colegas e companheiros por seus pontos de vista, pela carência e pelo amor compartilhados, agradeço por cantarolar, deixar bilhetinhos, pagar uma bebida, por desconfiar e acreditar em mim, agradeço por estarem pertinho ou longe, dizerem não e sim, por se importar, ligar ou aparecer, por sofrer junto e celebrar ainda que separados. Muito obrigado por aprendermos juntos e que possamos apreciar a vida que acontece nos detalhes, apesar das incertezas, tristezas e incompreensões. Reconheçamos os limites e as possibilidades, as alegrias e parcerias da jornada.

Ao Rafael B. de Moura e a Ana Galvão pelo apoio e broncas decisivos para que eu percebesse o chão e o céu, pela atenção e paciência em muitas doses até vislumbrar a gigantesca força e o potencial em cada pensamento positivo e decisão para continuar. A Cintia Costa, Elio Portella, Carolyna Barroca e Marta Maia por ouvirem desabafos, por serem firmes e precisos nos argumentos que derrubaram sucessivamente qualquer reticência e autocomiseração. Cada um lida como pode com seus problemas e vocês ainda se doam a outrem, simplesmente por compreender que não poderia ser de outra forma. A Érika P. Lins por ser extraordinária, Deus gosta especialmente de você. A Isabel Lima, Daniela Valla e Denize Alvarenga por serem exemplos de mulheres, professoras e cidadãs, em seus nomes agradeço a todas as professoras, professores, alunas e alunos com quem pude aprender e partilhar o gosto pela descoberta. A Angela, Carla, Carolina, Carolina, Dimas, Elisa, Jessica, João, Joyci, Laryssa, Liliane, Renata, 
Roberta e Rosa por constituírem a turma que precisávamos e merecíamos. Que possamos comemorar as felicidades e conquistas de cada um e afogar mágoas, contem comigo sempre! A Cecília, Priscila, Malu, Vanusa e Ana Luísa pelas trocas e enriquecedoras discussões no SOCED sobre as pesquisas, a arte e a política.

Aos Professores Isabel Lelis, Flávia Sarti, Murillo Marschner e Maria Ligia por aceitarem avaliar minha dissertação e contribuir para a minha formação como pesquisador em educação. A Cristina Carvalho, Giseli Barreto, Benedita Aglai e Ana Prado pela colaboração nas coordenações dos cursos de licenciatura, nos quais se formaram os professores iniciantes que participaram dessa pesquisa.

Meu agradecimento especial a todos vocês, colegas professores, que cederam as informações, inseguranças e pontos de vista sobre nossa profissão. Compartilhamos o desejo de fazer o melhor pela educação e a intenção de contribuir com o amadurecimento e a superação de nossos parceiros, os estudantes.

A Zaia Brandão por sua generosidade, confiança e rigor. Agradeço imensamente por compartilhar conosco suas inquietações e vigilância epistemológica. Você instiga a dedicação e o estudo sistematizado, para que a investigação avance e que a contribuição da pesquisa seja reformular as perguntas e as hipóteses. Muito mais do que orientadora acadêmica, você nos aconselha a viver a simplicidade, perseguir a qualidade e evitar a vaidade. Obrigado por fazer parte do meu início de carreira e espero contar com sua experiência para o meu desenvolvimento pessoal e profissional.

Ao $\mathrm{CNPq}$ e a FAPERJ pelo investimento durante a realização do curso. O financiamento público de pesquisas e o incentivo à qualificação profissional e à produção científica são fundamentais para o desenvolvimento do país. Que os órgãos de fomento à pesquisa e os representantes públicos nas três esferas de governo valorizem os pesquisadores iniciantes e priorizem a educação e a ciência como fundamentos para uma sociedade democrática. 


\section{Resumo}

Casciano, Rômulo Loureiro; Brandão, Rosaly Hermengarda Lima. A profissionalidade docente de professores iniciantes: um estudo com licenciados em Pedagogia e em Biologia. Rio de Janeiro, 2016. 142p. Dissertação de Mestrado - Departamento de Educação, Pontifícia Universidade Católica do Rio de Janeiro.

O presente texto apresenta um estudo com os licenciados em Pedagogia e em Biologia com enfoque nas representações sobre a profissão docente. A análise sobre a formação inicial e a atuação profissional nos primeiros anos de carreira buscou evidenciar o ponto de vista desses professores na construção da identidade profissional. Em tempos de reformas na estrutura e funcionamento dos sistemas de ensino e no papel dos professores, se faz necessário tensionar as motivações, disposições e os valores manifestados por aqueles que se inserem nesse campo. A polissemia de conceituações teóricas e suas interfaces são debatidas a fim de identificar as especificidades da docência como atividade em vias de profissionalização e reconhecer as múltiplas influências que levam alguém a se tornar professor. O material empírico foi produzido por 195 questionários respondidos por egressos dessas licenciaturas, formados no período de 2008 a 2015. As categorias analíticas utilizadas foram professores iniciantes, profissionalidade, profissionalização e trabalho docente. Na opinião desses professores, o excesso de teorizações e a falta de abordagens práticas das funções docentes na formação inicial a tornam insuficiente, o que gera sentimentos de insegurança e o choque de expectativas com o mundo real do trabalho. Há o reconhecimento de cada vez mais exigências para o desempenho dos professores, embora estes não participem das instâncias de regulação e controle da profissão. Somado a isso, a precarização das condições, o desprestígio social e os efeitos da responsabilização pessoal sobre a eficiência no trabalho constituem os desafios para socialização e o desenvolvimento profissional do magistério.

\section{Palavras-chave}

Professores iniciantes; Profissionalidade; Profissionalização; Trabalho docente. 


\section{Abstract}

Casciano, Rômulo Loureiro; Brandão, Rosaly Hermengarda Lima (Advisor). The teaching professionality of beginning teachers: a study of graduates in Pedagogy and Biology. Rio de Janeiro, 2016. 142p. MSc. Dissertation - Departamento de Educação, Pontifícia Universidade Católica do Rio de Janeiro.

This document presents a study of graduates in Pedagogy and Biology with a focus on representations of the teaching profession. The analysis of the initial training and professional practice in the early years of career sought to highlight the point of view of these teachers in the construction of their professional identity. In times of changes in the structure and functioning of education systems, and the role of teachers, it is necessary to tighten the motivations, dispositions and values expressed by those who are part of this field. The polysemy of theoretical concepts and their interfaces are discussed in order to identify the teaching specificities as an activity in the process of professionalization, and to recognize the numerous influences that lead someone to become a teacher. The empirical material was produced by 195 questionnaires filled by graduates, formed from 2008 to 2015. The analytical categories used were beginning teachers, professionality, professionalization, and teaching work. According to these teachers, excessive theorizing and lack of practical approaches of teaching duties in the initial training makes it insufficient, and generates insecurity and the clash of expectations with the real world of work. There is a recognition of increasing requirements for the performance of teachers, although they do not participate in the instances of profession regulation and control. Added to this, the precarious conditions, lack of social prestige, and the effects of personal accountability on efficiency at work are the challenges for socialization and professional development of teachers.

\section{Keywords}

Beginning teachers; Professionality; Professionalization; Teaching work. 


\section{Sumário}

$\begin{array}{ll}\text { 1. Introdução } & 14\end{array}$

2. Profissão Professor: o que é o trabalho docente? 20

2.1. A formação de professores profissionais 22

2.2. A profissionalização dos professores 28

2.3. Desenvolvimento profissional docente $\quad 40$

3. Jornada teórico-metodológica 46

3.1. A elaboração do questionário 51

3.2. Dos egressos aos professores iniciantes 54

3.2.1. Os produtores do corpus da pesquisa 55

4. Representações sobre a formação e o trabalho docente 59

4.1. Da universidade às escolas: Os egressos 59

4.2. Tornar-se professor: Os iniciantes 76

4.3. A busca pelos saberes profissionais dos professores 98

5. Considerações finais 114

6. Referências bibliográficas 119

$\begin{array}{ll}\text { 7. Apêndices } & 129\end{array}$ 


\section{Lista de Gráficos}

Gráfico 1 - Tipo de Ensino Médio frequentado 62

Gráfico 2 - Motivações para escolha do curso de licenciatura 63

Gráfico 3 - Experiências formativas ao longo da graduação 67

Gráfico 4 - Relevância das disciplinas do curso de licenciatura $\quad 68$

Gráfico 5 - Avaliação da formação inicial frente a atuação como professor $\quad 71$

Gráfico 6 - Situação após concluir a licenciatura 74

Gráfico 7 - Formas de inserção no mercado de trabalho como

professor $\quad 78$

Gráfico 8 - Distribuição dos professores iniciantes em função da dependência administrativa do local de trabalho 78

Gráfico 9 - Tempo após concluir a licenciatura e o primeiro emprego como professor

80

Gráfico 10 - Tempo de atuação como professor 81

Gráfico 11 - Distribuição dos professores iniciantes em função do nível de ensino onde lecionam 82

Gráfico 12 - Quantidade de empregos como professor 83

Gráfico 13 - Quantidade de horas por semana no local de

trabalho

Gráfico 14 - Quantidade de horas por semana de trabalho feito em casa

Gráfico 15 - Renda Mensal como professor

Gráfico 16 - Formas de acolhimento institucional experimentadas no primeiro emprego

Gráfico 17 - Sentimentos mais comuns nos primeiros meses/anos na carreira docente

Gráfico 18 - Motivações para realização de curso de formação continuada ou de qualificação profissional 95

Gráfico 19 - Motivações para o abandono do magistério 97

Gráfico 20 - Características do magistério/docência como atividade profissional 
Gráfico 21 - Envolvimento do professor com o trabalho

Gráfico 22 - Motivações do professor para o desenvolvimento do trabalho

Gráfico 23 - Fatores de influência sobre o desempenho do professor

Gráfico 24 - Aprendizados e crenças associados ao trabalho do professor nos primeiros anos da carreira 


\section{Lista de Quadros}

Quadro 1 - Tamanho das populações amostrais e quantidade de participantes da pesquisa 58

Quadro 2 - Distribuição dos egressos por faixas etárias e sexo 61

Quadro 3 - Nível de escolaridade das mães e dos pais 61

Quadro 4 - Situação após concluir a licenciatura 75 


\section{Lista de abreviaturas e siglas}

ANPED - Associação Nacional de Pós-Graduação e Pesquisa em Educação

BIO - Curso de Licenciatura em Biologia

cf. - conforme

CNPq - Conselho Nacional de Desenvolvimento Científico e Tecnológico

CNS/MS - Conselho Nacional de Saúde/Ministério da Saúde

CONEP - Comissão Nacional de Ética na Pesquisa

ENADE - Exame Nacional de Desempenho dos Estudantes

ENDIPE - Encontro Nacional de Didática e Práticas de Ensino

FAPERJ - Fundação Carlos Chagas Filho de Amparo à Pesquisa do Estado do Rio de Janeiro

FENEP - Federação Nacional das Escolas Particulares

LDB - Lei de Diretrizes e Bases da Educação Nacional

IBGE - Instituto Brasileiro de Geografia e Estatística

IES - Instituição de Ensino Superior

INEP - Instituto Nacional de Estudos e Pesquisas Educacionais Anísio Teixeira

IPEA - Instituto de Pesquisa Econômica Aplicada

MEC - Ministério da Educação

n.p. - não paginado

OCDE - Organização para a Cooperação e Desenvolvimento Econômico

ONG - Organização Não Governamental

PED - Curso de Licenciatura em Pedagogia

PNAD - Pesquisa Nacional por Amostra de Domicílios

PNE - Plano Nacional de Educação

PUC-Rio - Pontifícia Universidade Católica do Rio de Janeiro

RAIS/MTE - Relação Anual de Informações Sociais/Ministério do Trabalho e Emprego

SINAES - Sistema Nacional de Avaliação da Educação Superior

SOCED - Grupo de Pesquisas em Sociologia da Educação

TCLE - Termo de Consentimento Livre e Esclarecido

UNESCO - Organização das Nações Unidas para a Educação, a Ciência e a Cultura 
"Esta construção de identidade para si no confronto com o mercado de trabalho ou com os "sistemas de emprego" é hoje coincidente com o "drama social do trabalho", de que falava Hughes, já que, para uma fracção dos jovens, ela implica o risco de uma exclusão durável de um emprego estável e, para todos os jovens, ela exige a invenção de estratégias pessoais de apresentação de si ("aprender a vender-se"), que ameaçam ser determinantes para o desenvolvimento futuro da sua vida profissional. Não se trata somente de uma situação de "escolha do oficio" ou de obtenção de diplomas, mas da construção pessoal de uma estratégia identitária que põe em jogo a imagem do eu, a apreciação das suas capacidades, a realização dos seus desejos.” (DUBAR, 1997, p. 114) 


\section{Introdução}

A presente pesquisa buscou investigar como se dá a construção da identidade docente e compreender os caminhos e as percepções sobre a profissão de dois grupos de licenciados no início de suas carreiras como professores.

A motivação para estudar esse tema tem sua origem a partir de minha trajetória de formação inicial em Ciências Biológicas e por eu mesmo fazer parte do grupo de professores em início de carreira. Elementos de autoanálise sobre os primeiros anos de magistério, sobre minha experiência e socialização como professor da Educação Básica e sobre as finalidades da Educação me levaram de volta à universidade em busca de diálogos formativo-reflexivos. Encontrei parceiros de conversa, dispostos a compartilhar tempo e vivências, preocupações e perguntas, além de ferramentas e suporte para reflexão e busca de algumas respostas.

Inicialmente, ao fazer o processo seletivo para entrar no programa de pósgraduação, pensava em buscar compreender no estágio em docência dos cursos de licenciatura quais seriam as características e as práticas que nos tornam professores, e ainda cogitava a possibilidade de investigar a formação continuada. Havia interesses e temas amplos e sem delimitação ou recorte de investigação. Com a minha entrada no curso de Mestrado, eles foram sendo refinados em torno da temática que ora apresento.

A entrada no Grupo de Pesquisas em Sociologia da Educação (Soced) também contribuiu para pensar o momento de entrada na docência, após a conclusão do curso de licenciatura, bem como incluir o curso de Pedagogia na proposta de estudo, uma vez que o Soced há algum tempo vem analisando a formação de professores, o curso e os estudantes dessa licenciatura. A intenção de investigar os jovens professores licenciados em Biologia e Pedagogia começava a tomar delimitação e sistematização metodológica.

A opção por se investigar os licenciados em duas carreiras universitárias e categorias profissionais do magistério tem a ver com as possíveis diferenças e 
semelhanças na socialização profissional (GUIMARÃES, 2006; LÜDKE, 1996), entre professores oriundos de um curso mais generalista em termos de conteúdos escolares, como o curso de Pedagogia, e um curso com diretriz mais específica ou especializada, como o curso de Ciências Biológicas. Além disso, espera-se levantar algumas questões sobre a formação e o trabalho docente (OLIVEIRA, 2010), suas possíveis relações e ainda as percepções sobre a profissão. Portanto, parece-me necessário conhecer as questões convergentes e divergentes dos egressos desses cursos de licenciatura ao longo de sua inserção profissional, enfatizando o período de entrada na carreira (HUBERMAN, 1992).

Ao colocar em foco a profissionalidade docente (LÜDKE; BOING, 2010) na perspectiva do professor iniciante buscou-se compreender as características requeridas e desenvolvidas para o exercício da profissão professor. Em tempos de reformas na estrutura e no funcionamento dos sistemas de ensino e no papel dos professores, se faz necessário tensionar as motivações, disposições e os valores manifestados por aqueles que se inserem nesse campo. Nesse sentido, o momento de entrada na docência é entendido como espaço-tempo privilegiado na construção da identidade profissional, somado à formação inicial e ao exercício do magistério em seus múltiplos contextos de trabalho.

Espera-se contribuir para a compreensão acerca das motivações de entrada no curso de formação de professores, da relação entre teoria e prática nas disciplinas de graduação e a relevância destas para o trabalho docente na educação básica. O debate sobre o desenvolvimento profissional visa conhecer as perspectivas e os comprometimentos assumidos por esses professores iniciantes na docência.

O conceito de profissionalização docente (SHIROMA; EVANGELISTA, 2010) presente na literatura científica e nos argumentos de legisladores e gestores públicos precisa ser investigado e debatido também de acordo com as impressões e ressignificações conferidas por aqueles que são os protagonistas desses discursos: os professores. Associar esse movimento com a formação de professores visa superar a dicotomia entre formação inicial e formação em serviço, valorizando os saberes/competências e as descobertas/aprendizagens da prática docente.

A compreensão do desenvolvimento profissional dos professores como um contínuo - que se inicia com as experiências como aluno da educação básica, 
seguidas por aquelas da graduação e pelas experiências e trocas ao longo do exercício profissional - parte da perspectiva do acúmulo, reflexão e transformação de atitudes, estratégias e características que definem a profissão. Assume-se a construção de identidades profissionais e grupos profissionais a partir da socialização de vivências (DUBAR, 1997), confrontadas com o cotidiano e os contextos de trabalho.

A tentativa de produzir um olhar sociológico sobre tal temática visa desprender-se de julgamentos e apriorismos, considerar contextos e experiências individuais e coletivas de ação, ponderar as relações estabelecidas entre agentes e estruturas e contribuir para a compreensão desses fatos e fenômenos sociais. Weber $(2009$, p. 3) ao falar sobre a Sociologia, a define como "ciência que pretende compreender interpretativamente a ação social e assim explicá-la causalmente em seu curso e em seus efeitos". Essa assertiva nos leva ao exercício de tentar compreender a realidade e interpretá-la, de modo parcial e temporário. O autor afirma ainda que a Sociologia busca através da conceituação:

(...) em todos os casos, racionais [orientados por valores ou por fins] como irracionais [místicos, proféticos, inspiracionais, afetivos], ela se distancia da realidade, servindo para o conhecimento desta da forma seguinte: mediante a indicação do grau de aproximação de um fenômeno histórico a um ou vários desses conceitos (WEBER, 2009, p. 12)

A perspectiva adotada na elaboração desse texto é argumentar com base em análises teóricas e empíricas sobre a profissão docente acerca das fragilidades da formação do professor, das dificuldades no momento de inserção profissional e da atribuição genérica de saberes docentes. As escolhas teórico-metodológicas para essa abordagem investigativa contaram com abertura de referenciais, o que levou à amplitude de dados. A linha condutora foi o entendimento da formação como um processo contínuo que atravessa momentos e espaços de socialização.

A contribuição da Sociologia, tal como definida por Karabel e Halsey (1997), foi nosso guia e modelo para problematizar as contribuições do levantamento bibliográfico e do material empírico produzido juntamente com os informantes dessa pesquisa. Estar atento ao rigor científico é um duplo movimento de assumir as possibilidades, os interesses/objetivos, e reconhecer os limites da abordagem que se propôs cumprir, sem desconsiderar que esse será 
mais um ângulo e foco de análise possível, dada a parcialidade e interinidade inerentes à atividade de pesquisa.

Dessa forma, tanto a escolha de um problema de pesquisa, quanto a maneira de tratá-lo são influenciadas por nossa inserção em um dado ambiente/contexto social e, especialmente, por nossos valores pessoais. Aquiescer à proposição desses autores é concordar que é "plausível sugerir que fatores sociais são mais relevantes em questões de ênfase e negligência do que em questões de validade e erro" (KARABEL; HALSEY, 1997, p. 7-8).

Interessa-me, portanto, tentar compreender representações, sentidos, estratégias e relações com o trabalho e o conjunto de possibilidades e limites experimentados pelos professores no início de suas carreiras, uma vez que eu também me considero um professor iniciante. De que forma essas experiências se constituem na formação da identidade profissional e como impactaram sua visão a respeito da profissão e do futuro profissional. Quais os comprometimentos que são desenvolvidos ao longo de sua inserção nesse campo profissional: se e como é apropriada a noção de autonomia e quais outras posturas acerca da profissionalidade (relação com os saberes, com as aprendizagens, com as instâncias de regulação e controle da atividade profissional e com as funções sociais desempenhadas) são construídas em torno de sua prática docente institucional.

Ao assumir uma perspectiva relacional (BOURDIEU, 1989) - tanto para os sujeitos professores e o seu campo de atuação da profissão docente, quanto para as aproximações e a operacionalização das teorias, metodologia e empiria - esta pesquisa segue a abordagem de Chartier (1990) para pensar uma história cultural a partir das representações do mundo social. Com esse autor, entendemos por representação aquilo que

permite articular três modalidades da relação com o mundo social: em primeiro lugar, o trabalho de classificação e de delimitação que produz as configurações intelectuais múltiplas através das quais a realidade é contraditoriamente construída pelos diferentes grupos; seguidamente, as práticas que visam reconhecer uma identidade social, exibir uma maneira própria de estar no mundo, significar simbolicamente um estatuto e uma posição; por fim, as formas institucionalizadas e objectivadas graças às quais uns "representantes" (instâncias coletivas ou pessoas singulares) marcam de forma visível e perpetuada a existência do grupo, da classe ou da comunidade. (Chartier, 1990, p. 23) 
A identidade profissional é fruto da tensão e apropriação de disposições, características e posicionamentos ao longo das disputas que ocorrem nos ambientes de formação e trabalho. De maneira a tentar compreender as estratégias e relações que os professores estabelecem ao iniciar suas carreiras profissionais, os conceitos de campo, habitus e capital de Pierre Bourdieu foram utilizados de maneira operatória (BRANDÃO, 2002; 2010), isto é, ao longo da discussão dos referenciais teóricos, na elaboração do instrumento de produção dos dados empíricos e sua análise.

A mobilização e o aprendizado de saberes próprios da profissionalidade docente, ou aprendizagem da docência (cf. NETO; SARTI; BENITES, 2012), são alvo dessa investigação a partir do levantamento de elementos de socialização e imissão de características para tornar-se professor, após a conclusão da graduação e nos primeiros anos de exercício da profissão. O estudo sistemático de Pierre Bourdieu possibilitou pensar relacionalmente o objeto de análise e tensionar as relações entre as estruturas e os agentes envolvidos na construção social que são as profissões, bem como identificar as disposições aprendidas e requeridas nos contextos de atuação do trabalho docente, como tem sido feito pelas investigações consultadas.

A compilação de achados e tendências sugeridos pela literatura na etapa de revisão teórico-empírica do tema proposto nesta pesquisa levou à formulação das seguintes hipóteses: 1) A formação inicial dos docentes contribui pouco para o exercício profissional; 2) $\mathrm{O}$ distanciamento entre teoria e prática e a falta de debates sobre as realidades de trabalho do professor são características das deficiências dos cursos de licenciatura; 3) A facilidade de acesso e o desprestígio dos cursos de formação de professores interferem na socialização profissional e na construção da identidade docente; 4) Os egressos dos cursos de Biologia e de Pedagogia apresentam as mesmas características de entrada na docência e desenvolvem estratégias semelhantes para construção do perfil profissional como professores da educação básica.

A partir desses achados e hipóteses, foram delineadas algumas questões de pesquisa: Qual o destino profissional dos licenciados em Ciências Biológicas e Pedagogia no início da carreira docente? Dito de outra maneira: os egressos desses cursos tendem a exercer a profissão docente a qual estão qualificados? Se não o fazem, que outros caminhos profissionais buscam? Quais as dificuldades 
encontradas e quais as estratégias adotadas por estes professores diante da realidade do trabalho na educação básica? Há similaridades/divergências nas formas de socialização profissional entre esses dois grupos de licenciados? Que atributos e características profissionais são apontados como mais relevantes para carreira docente? O que pensam sobre a formação inicial e quais relações são feitas desta com o exercício da profissão? Que saberes ou conhecimentos profissionais são adquiridos no exercício da profissão e qual a importância deles?

O presente estudo, realizado com os licenciados egressos dos cursos de Ciências Biológicas e Pedagogia de uma universidade federal na cidade do Rio de Janeiro, com até seis anos de docência, buscou alcançar os seguintes objetivos:

- Analisar a constituição da identidade profissional, a partir da escolha pelo curso, da relevância da formação inicial e das percepções sobre o início da docência.

- Levantar as motivações que conduziram à essa profissão e as perspectivas de permanência/abandono da mesma.

- Identificar que atributos, características e estratégias são valorizados na construção da profissão docente no início da carreira. 


\section{2 Profissão Professor: o que é o trabalho docente?}

A proposta desse capítulo é fazer um esboço de análise das pesquisas sobre formação de professores e os enfoques e encaminhamentos adotados e sugeridos por pesquisadores acerca do período de entrada na carreira docente e da profissionalização do magistério. O desafio é indicar, a partir de estudos do tipo revisão e balanço além de contribuições da Sociologia das Profissões, algumas questões a serem consideradas na investigação das representações sobre a formação e a profissão docente na perspectiva de professores iniciantes.

Popkewitz (1995) nos alerta sobre a não universalidade do termo profissão dadas as diferenças linguísticas e culturais entre as tradições anglo-americanas e europeias, e ainda a diversidade no desenvolvimento do Estado e consolidação dos dispositivos de formação e atuação de atividades da classe média. Como discutido por Lelis (1996, p. 209), a categoria profissional do magistério não deve invisibilizar "a polissemia de uma profissão, encarnada em trajetórias que encerram projetos e sonhos, medos e esperanças, competências e habilidades construídas no percurso". Essa ressalva é importante uma vez que os professores constituem um grupo funcional de trabalho peculiar, ligado à identificação de um tipo ideal de ocupação altruísta, à especialização no processo de produção e emprego nas sociedades modernas, à obrigatoriedade de escolarização e aos debates ideológicos subsequentes à essa função do Estado.

$\mathrm{O}$ autor pondera que as características que servem para definir uma profissão (autonomia, conhecimento técnico, controle sobre as remunerações e ética) deveriam considerar as lutas políticas, os confrontos e os compromissos envolvidos na constituição dos grupos profissionais. Com base em sociólogos americanos, Popkewitz (1995, p. 40) apresenta a problemática sobre a profissionalização e a identidade profissional do professor diante das reformas educacionais promovidas pelo Estado e do lugar e finalidade dessa ocupação, na estrutura social. 
O rótulo profissão é utilizado para identificar um grupo altamente formado, competente, especializado e dedicado que corresponde efectiva e eficientemente à confiança pública. (...) As profissões fizeram dos seus serviços um meio de troca para a obtenção de prestígio, poder e estatuto económico. O serviço não era tão altruísta com parecia ser, nem os interesses profissionais tão neutros quanto se proclamava ou quanto se pretendia que os clientes acreditassem.

Elementos dessas mudanças nas definições da atuação docente serão discutidos ao longo das seções desse capítulo, que enfoca também a polissemia das vertentes teóricas que discutem a epistemologia e a especificidade do trabalho do professor. A título de preparação para a leitura, importante lembrar a origem do termo docência, tal como apresentado por Oliveira (2010, n.p.): "significa ensinar, instruir, mostrar, indicar, dar a entender, podemos afirmar que o trabalho docente é o que se realiza com a intenção de educar".

Para além de "uma aceitação tácita do magistério como profisssão" (CUNHA, 1999, p.132), definições não devem ser tomadas de forma acrítica ou isentas das ressignificações contextualizadas pela prática e pelas lutas simbólicas. A discussão feita por Marin (1996), ao caracterizar o trabalho docente pelo conjunto de informações, questões, temas e problemas referentes à atividade didática, apresenta a fragmentação dos estudos no campo da Educação, que levaram, segundo a autora, a um tecnicismo crescente e caracterizado pela dispersão dos esforços de pesquisa na área.

Corroborar com sua abordagem é tomar o trabalho do professor em função do conjunto de rotinas e procedimentos dos contextos de exercício e pela perspectiva do ensino: "ensinar, frequentemente, é atividade profissional e, como tal, supõe formação especializada para quem o executa”, uma atividade exercida em unidades escolares, sob determinada organização do trabalho "sujeito a limitações, exigências e possibilidades permitidas pelo sistema social mais amplo" (MARIN, 1996, p. 28, grifos meus).

Mas, como bem alerta Oliverio (2014, p. 244) ser professor engloba muito mais do que a função do ensino e inclui desafios que surgem simultaneamente quando na entrada dos iniciantes nesse campo profissional:

envolve saber atuar em um contexto específico; lidar com normas e regras que conformam a sua atuação e com políticas que afetam o seu trabalho e o seu modo de se constituir como professor; conviver com um grupo de trabalho; compartilhar objetivos e um projeto de escola; lidar com a diversidade dos alunos; saber se posicionar em seu subcampo etc. 


\section{1.}

\section{A formação de professores "profissionais"}

A formação de professores emerge como questão de pesquisa a partir dos processos de expansão e democratização do acesso aos sistemas formais de ensino. Se anteriormente ${ }^{1}$ o exercício do magistério era pertinente àqueles de notório saber e dedicados à nobre tarefa de partilhar os conhecimentos acumulados e "instrução popular", a demanda por mais professores, que atendessem de forma padronizada um contingente cada vez maior de alunos, levou a criação de espaços formativos e a constituição de um novo profissional.

O investimento dos governos e das instituições criadas com a finalidade de fornecer a formação e a certificação para os novos professores caminhou no sentido da elaboração de um conjunto de conhecimentos, conteúdos e habilidades creditados como necessários para o exercício da docência. $\mathrm{O}$ aspecto científico dos métodos de ensino e dos conhecimentos legítimos para a ação educativa somados aos comportamentos e hábitos desejados para a vida em sociedade formaram o arcabouço das atividades pedagógicas. A prática professoral é marcada, no entanto, por um habitus e um ethos escolares, que por sua vez, apresentam distâncias e discrepâncias variadas da cultura e dos hábitos sociais em função da diversidade de classes e acesso à cultura. No interior das escolas, se dá um confronto entre a diversidade de referências culturais, trazidas por indivíduos que nelas passaram a se reunir e com aspirações sociais que o acesso à educação passou a oferecer, tanto às novas gerações de alunos, quanto aos novos professores. Entretanto, como toda construção social, a profissão docente tem sofrido alterações com o passar do tempo, refletindo em seus processos formativos e na atuação de seus membros outras disposições, características e sentimentos.

A inspiração para o perfil docente no âmbito da escola moderna foi daqueles que tivessem vocação para intelectualidade e trato com crianças e adolescentes. A crescente demanda por professores exigiu a definição de conteúdos e metodologias a partir dos quais o ensino pudesse ser empreitado como dever de Estado. A padronização de aspectos formativos e laborais, além da certificação

\footnotetext{
${ }^{1}$ Para maiores detalhes sobre aspectos históricos da formação de professores no Brasil consultar Saviani (2009).
} 
para o trabalho, levou ao surgimento de cursos e instituições dedicadas à formação de professores (e de outros integrantes do quadro funcional das escolas). A formação específica desses trabalhadores e o atendimento satisfatório de uma clientela fundado na realização de um serviço sistematizado teoricamente vão ao encontro de uma cultura profissional. Conforme apontam as contribuições de autores da Sociologia das Profissões (ALMEIDA, 2010; BARBOSA, 2003).

A formação de professores como objeto de investigação sofre com "a falta de delineamento de um campo próprio da formação de profissionais da educação" (BRZEZINSKI, 2014, p.102). A assertiva nos oferece uma das interpretações acerca da baixa densidade de pesquisas (dissertações, teses e artigos na área de Educação) sobre tal temática, tal como apontam os balanços e estudos de revisão da publicação na área (ANDRÉ et al, 1999; BRZEZINSKI, 2014; BRZEZINSKI; GARRIDO, 2001). Outra questão suscitada é a denominação "profissionais da educação", que expandiu a compreensão dos trabalhadores que atuam nos processos de escolarização e ensino-aprendizagem, atribuindo-lhes uma unidade identitária.

De acordo com os trabalhos citados, as pesquisas discentes (mestrado e doutorado) realizadas sobre a formação de professores nos períodos analisados (1992-1998 e 2003-2010) ocupam uma parcela de 5\% a 10\% do total da produção na área de Educação, sendo que os trabalhos que abordam a identidade profissional e a profissionalização docente se restringem, em média, entre $10 \%$ e 20\% dessa faixa. Já os estudos publicados em periódicos e no Grupo de Trabalho Formação de Professores da Associação Nacional de Pós-Graduação e Pesquisa em Educação alcançam percentagens entre $17 \%$ e $28 \%$ do total de artigos. Há mais de 15 anos, André et al (1999, p. 303) alertavam sobre a importância de se abordar tal temática e sua ligação com outras relativas ao exercício da profissão:

Identidade e profissionalização docente surge como tema emergente nos últimos anos, e abre perspectivas para questões de grande interesse e atualidade, como a busca da identidade profissional do docente, a relação do professor com as práticas culturais, questões de carreira, organização profissional e sindical, e questões de gênero.

Ainda na década de 1990, a lei 9.394 (Lei de Diretrizes e Bases da Educação Nacional - LDB), determinava a formação em nível superior dos "Profissionais da Educação" (BRASIL, 1996) enfatizando uma maior qualificação formativa. A 
influência legal $^{2}$ sobre a profissão e profissionalização docente, levou à constatação de que a maior preocupação dos pesquisadores foi com a formação docente em nível superior.

Verificamos um grande esforço dos investigadores para aprofundar o conhecimento dos problemas existentes nos cursos de pedagogia e na licenciatura e propor alternativas para superá-los, visando à melhoria da formação dos licenciandos. (BRZEZINSKI; GARRIDO, 2001, p. 83)

As autoras relatam as preocupações com a fragmentação da formação universitária dos professores em decorrência da estrutura departamental imposta pelas reformas do nível superior feitas na década de 1960, que refletem diretamente sobre os relatos de contradições entre disciplinas teóricas ou de conteúdos disciplinares e disciplinas metodológicas ou didático-pedagógicas. A dicotomia entre teoria e prática na formação e na atuação dos professores da educação básica é uma questão posta na literatura da área (GATTI, 2010; SAVIANI, 2009), que permanece um desafio para ambas as instâncias e mobiliza pesquisadores, inclusive para fornecer subsídios que venham a aumentar a atratividade do ensino para as novas gerações de alunos.

\begin{abstract}
A insistência com a relação teoria e prática decorre do conceito de competência: competência se constrói em situação; não é "conhecimento de", muito menos "conhecimento sobre", mas é conhecimento que pode ser mobilizado para agir e tomar decisões em situações concretas. Situações da vida real envolvem sempre um componente imponderável e imprevisível. (MELLO, 2000, p. 103)
\end{abstract}

Saviani (2009) ao descrever a origem dos cursos de licenciatura (incluindo o curso de Pedagogia) afirma a presença marcante dos conteúdos culturaiscognitivos (conhecimentos disciplinares atribuídos aos institutos ou faculdades específicos) e que mesmo as discussões de caráter pedagógico-didático (a cargo das faculdades de educação) tenderam para uma abordagem conteudista e não uma forma de problematizar e refletir sobre a prática docente. $\mathrm{O}$ autor ainda oferece uma crítica aos modelos de formação aligeirados e de baixo custo que, mesmo após a promulgação da LDB em 1996 e a homologação das diretrizes curriculares para o curso de Pedagogia em 2006, não se desvencilharam de um

\footnotetext{
${ }^{2}$ Para um histórico das determinações legais desde a criação das Escolas Normais até a
} 
"nivelamento por baixo", onde "é a precariedade das políticas formativas, cujas sucessivas mudanças não lograram estabelecer um padrão minimamente consistente de preparação docente para fazer face aos problemas enfrentados pela educação escolar em nosso país.” (SAVIANI, 2009, p. 148)

Mello (2000) vai além na crítica ao afirmar que tal modelo de formação inicial imprime uma "identidade pedagógica esvaziada de conteúdo", à medida que coexiste uma não apropriação do conteúdo a ser ensinado pelos professores e que o contexto institucional dos cursos de graduação estão deveras distanciados das preocupações e dificuldades da educação básica. A autora assinala ainda o descompromisso dos professores universitários com o ensino em geral, em função da dedicação com as atividades de pesquisa, e a ausência de avaliações sérias e um controle maior do Estado sobre o credenciamento dos cursos de preparação docente, até o ano de 1999 - a partir do qual o Instituto Nacional de Estudos e Pesquisas Educacionais Anísio Teixeira (INEP) incluiu as licenciaturas no Exame de Avaliação de Cursos (Provão).

A autora segue sua argumentação em torno do papel reflexivo do professor, competente, no sentido de estar apto a refletir sobre as decisões que toma para melhorar sua prática e defende a profissionalização que possibilite a auto avaliação e "agir com autonomia diante dos conflitos e dilemas éticos de sua profissão, e de sua capacidade em gerenciar seu próprio desenvolvimento profissional por meio de um processo de educação continuada." (MELLO, 2000, p. 106).

Rememorar a discussão sobre o sistema educacional funcionar como um elemento crucial na reprodução ${ }^{3}$ do sistema de desigualdades sociais e na divisão do trabalho faz-se necessário. Primeiro porque estamos todos nessa engrenagem de lutas pela sobrevivência e segundo porque não nos é permitido considerar quaisquer relações sociais e as construções identitárias delas decorrentes sem ponderar o conflito de interesses e as estratégias de manutenção das diferenças e desigualdades sociais.

Essa reflexão da dualidade ou dilema do modelo de formação de professores generalistas/polivalentes e especialistas é um dos pontos de investigação e 
contraste. A opção por pesquisar egressos da Pedagogia e da Licenciatura em Ciências Biológicas, vislumbra, identificar se esse modelo persiste e até que ponto influencia as práticas pedagógicas dos tipos de professores formados nesses cursos. Assumir a reflexividade (cf. SCHÖN, 1992) como uma das características necessárias para o novo perfil do professor é uma escolha pessoal, mas que tem aparecido nas pesquisas empíricas como sinal de afirmação do comprometimento e como estratégia de manter-se na profissão.

O destaque para análises sobre interdisciplinaridade ("integração entre disciplinas teóricas e práticas") na formação dos professores, o reconhecimento das escolas como espaço formativo ("vivência e reflexão sobre a prática") e a articulação destas com instituições de graduação e pós-graduação, sinalizam a emergência da compreensão dos novos perfis docentes (MELLO, 2000). No entanto, conforme aponta Gatti (2010) a relação "formação disciplinar/formação para a docência" continua na prática fragmentada, e instituído, desde a formação inicial, um valor social diferenciado entre o professor polivalente e o especialista. A autora aponta um avanço em relação aos papéis missionário e artesão da profissão docente, em função dos debates em torno da profissionalidade e profissionalização, mas sustenta a "pulverização na formação dos licenciados [como um indicador de fragilidade na] preparação para o exercício do magistério na educação básica" (GATTI, 2010, p. 1374).

Lüdke (2005) já apontava na década de $1980^{4}$ a indefinição dos termos profissão e educador, aplicados simultaneamente à ocupação dos professores, marcada pela multiplicidade de especialistas que definem o específico da formação profissional do grupo e suas divisões internas que estabelecem fatores de distinção que não favorecem a consolidação de uma profissão. Acrescenta que o caráter individualista entre os pares ao longo da iniciação na carreira e a falta de um compromisso entre o profissional e a profissão, no sentido de sua organização por associações profissionais, são pontos de vulnerabilidade e enfraquecimento do magistério como uma semiprofissão.

Brzezinski (2014) apresenta a mudança na forma de lidar e descrever o desenvolvimento das atividades docentes com a substituição do descritor "práticas pedagógicas". A autora pondera que "trabalho docente é a expressão do saber 
pedagógico, e este, ao mesmo tempo, é fundamento e produto das atividades docentes que se desenvolvem no contexto escolar, ou fora dele, em instituições sociais" (BRZEZINSKI, 2014, p. 32, grifo da autora). O conjunto de pesquisas a que se refere, analisam e valorizam os chamados "saberes e competências" que o professor desenvolve na prática e nos variados contextos de trabalho, conhecimento e habilidades ou estratégias que não são aprendidos na formação inicial. A autora aponta um crescimento significativo no percentual dos trabalhos analisados no triênio 2008-2010 com essa perspectiva, com destaque para aqueles reunidos nos descritores "formação inicial" e "trabalho docente".

As pesquisas sobre formação de professores, com destaque para os primeiros anos de carreira, é tema de poucas investigações no Brasil (CORRÊA; PORTELLA, 2012; LIMA, 2004; MARIANO, 2006; OLIVERIO, 2014; PAPI; MARTINS, 2010) $)^{5}$, além do fato de haver uma concentração de pesquisas no estado de São Paulo. No entanto, a importância desses estudos para a compreensão da formação inicial e da constituição da identidade profissional do professor está na potencialidade de subsidiar a criação de políticas e programas de incentivo e apoio aos docentes que ingressam na profissão, tal como se observa em alguns países e de forma muito incipiente no Brasil ${ }^{6}$ - onde "os professores em exercício ainda não desempenham o papel de tutores ou mentores, de quem se espera uma intervenção formativa diante dos futuros professores"7 (NETO; SARTI, BENITES, 2012, n.p.).

Seguindo a linha dos trabalhos da área de formação de professores, são apontadas como perspectivas parcerias entre instituições da educação básica e instituições de ensino superior (IES) e a realização de pesquisas que possam fomentar a formação específica e diferenciada do professor iniciante, a fim de diminuir as dificuldades por eles enfrentadas, o abandono da carreira e em favor da qualidade do ensino oferecido aos alunos. Também são sugeridas pesquisas

\footnotetext{
${ }^{4}$ Chama-se a atenção para a publicação original do livro em 1988 e desse texto em 1983.

${ }^{5}$ As obras citadas incluem, ou se propuseram a realizar, balanços e revisões sobre as publicações, por isso são apresentadas como referências para o tema.

${ }^{6}$ Para maiores detalhes sobre políticas e programas de iniciação à docência consultar Corrêa e Portella (2012) e André (2013).

7 A afirmativa dos autores foi feita na discussão da importância e dos desafios do estágio supervisionado na formação universitária. Sua utilização como argumento em programas de formação em serviço e formação contínua é condizente com o entendimento de um processo de socialização profissional que se estende ao longo da vida profissional.
} 
que evidenciem contextos em outras regiões do país, que apresentem experiências de sucesso profissional, para além da maior parte dos estudos que apontam aspectos negativos e dificuldades no início da carreira, e que avaliem a inserção de professores em diferentes níveis de ensino e redes de ensino.

\section{2. \\ A profissionalização dos professores}

A expansão do ensino superior objetivou atender as demandas por profissionais qualificados em diversas áreas. A partir da intensificação da oferta de Educação Básica pública obrigatória e da universalização do acesso da população à escolarização como direito fundamental para o desenvolvimento intelectual, a necessidade de aumentar a quantidade de professores e demais trabalhadores da Educação tornou-se um desafio para os governos. No entanto, podemos inferir que os investimentos públicos estão aquém do necessário tanto para garantir a expansão das redes e sistemas de ensino à população em idade escolar (e àquela defasada em anos por falta de oportunidades), quanto para oferecer boas condições de ensino e aprendizagem aos alunos e condições materiais e salariais condizentes ao trabalho docente, bem como para a formação contínua e adequada desses profissionais.

Sobre a expansão de oportunidades de acesso e permanência no sistema escolar, Oliveira (2007) afirma que, ao final do século XX, havia uma tensão entre a ampliação de vagas, a qualidade da educação básica e a redução de investimentos públicos nas políticas sociais em função das opções macroeconômicas de ajuste fiscal. No entanto, chama atenção que o processo de universalização do ensino fundamental gerou uma demanda por expansão de todo o sistema, tanto no ensino médio quanto no ensino superior e, ao mesmo tempo, "avulta a preocupação por qualidade, problema historicamente pouco visível diante dos mais evidentes e pungentes processos de exclusão gerados pelos altos índices de reprovação e evasão observados anteriormente" (OLIVEIRA, 2007, p. $667)$.

Conforme os dados do Censo Escolar 2012 (INEP, 2013), o Brasil possui 2.095.013 docentes atuando na Educação Básica, sendo 78,1\% destes com formação de nível superior, o que revela 458.807 professores sem diploma de 
graduação (formação mínima exigida para todo o ensino fundamental e médio). Além disso, levantamento ${ }^{8}$ feito pela organização não governamental (ONG) Todos pela Educação, com base nos dados do Censo 2013, revela que apenas $32,8 \%$ dos professores do ensino fundamental têm licenciatura nas disciplinas em que atuam; no ensino médio a taxa é de 48,3\%. A ONG chama a atenção para a Meta 15 do novo Plano Nacional da Educação $(\mathrm{PNE})^{9}$, que visa garantir uma política nacional de formação dos profissionais da educação e prevê que todos os professores da educação básica possuam formação específica de nível superior, obtida em cursos de licenciatura na área de conhecimento em que atuam. A falta de professores também é preocupação do Ministério da Educação (MEC) ${ }^{10}$, que reconhece o déficit de 246 mil professores para atender a todas as áreas do conhecimento na Educação Básica.

Diniz-Pereira (2011) afirma que já nas décadas de 1980 e 1990 havia sinais claros de uma crise da profissão docente no Brasil, citando pesquisas e estudos que apontavam as condições de trabalho e os baixos salários como fatores "deformadores" ou "desqualificadores" do magistério. As críticas sobre a formação inicial dos professores começavam a correlacionar o fracasso do trabalho docente à situação da carreira do professor: "O aviltamento salarial e a participação cada vez menor na execução do seu próprio trabalho revelaram a existência de um crescente processo de proletarização do magistério brasileiro" (HYPOLITO, 1991 apud DINIZ-PEREIRA, 2011, p. 37).

O autor aponta que a cisão entre pesquisa e ensino no âmbito das universidades trouxe prejuízos ao ensino e à formação profissional de professores, o que contribuiu para o desprestígio dos cursos de licenciatura em relação aos demais cursos de nível superior. Mas os problemas mais emergentes no período, e que nos parecem ainda preocupantemente atuais, foram a desarticulação entre “disciplinas de conteúdo" e "disciplinas pedagógicas" e a falta de problematização

\footnotetext{
${ }^{8}$ Material veiculado na página da ONG na internet: $51,7 \%$ dos professores do EM não têm licenciatura na disciplina que lecionam. Todos pela Educação. 14 abril 2014. Disponível em: <http://www.todospelaeducacao.org.br/reportagens-tpe/30096/483-dos-professores-ensino-mediotem-licenciatura-na-disciplina-que-ministram/>. Acesso em 07/12/2014.

${ }^{9}$ O novo PNE foi aprovado sob a forma da Lei 13.005 de 25 de junho de 2014. Para mais detalhes consultar Brasil (2015).

${ }^{10}$ A informação foi extraída a partir de reportagem veiculada no portal do MEC na internet: Falta de professores preocupa especialistas. Ministério da Educação. 14 fevereiro 2014. Disponível em:
} 
entre formação acadêmica e realidade da prática docente, como apontado anteriormente nos trabalhos de Mello (2000), Saviani (2009) e Gatti (2010). Tais críticas reúnem-se ainda hoje contra a dita má formação dos professores, mas não podemos deixar de considerar os dilemas e vicissitudes do cotidiano de trabalho, bem como os impactos da administração gerencial dos serviços públicos.

Shiroma (2004) afirma que diante das mudanças nas políticas educacionais implementadas no Brasil a partir da década de 1990, em sintonia com as recomendações de organismos internacionais, expressões como responsabilização pelos resultados, prestação de contas, accountability, captação e uso otimizado de

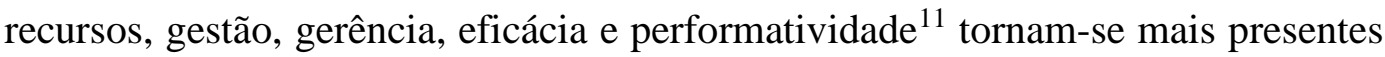
nos discursos educacionais e impactam no trabalho e na identidade dos professores. A autora sintetiza análises que indicam uma primeira geração de reformas onde se procedeu à reordenação do sistema educacional, à reforma de currículos, à avaliação e ao financiamento, e uma segunda geração que enfatizou a profissionalização do trabalho no interior da escola, tanto na gestão escolar quanto no trabalho desenvolvido pelos professores.

Sobre o discurso retórico do Estado a favor da profissionalização docente, associado à centralização das decisões didático-pedagógicas e à fixação de currículos e avaliações sem a participação dos professores - estes, supostamente os profissionais e especialistas responsáveis por tais funções no âmbito de seus contextos de trabalho -, Contreras (2012, p. 72) afirma:

Precisamente nesse tipo de processo de aspiração a um profissionalismo de efeitos duvidosos sobre a melhoria do trabalho docente, que alguns autores analisaram as armadilhas que dita aspiração supõe para o ensino e os professores, e como são usadas por parte do Estado em épocas de reforma, para assegurar a colaboração do professor e anular assim suas possíveis resistências à redefinição de sua função. (CONTRERAS, 2012, p.72)

A reforma educacional e suas lógicas "capitalista da escolarização" e da "pragmática empresarial" (CUNHA, 1999) obrigam os professores a uma nova identidade (submissa, vazia, superficial) e uma outra atuação profissional (concorrencial, burocrática, neurastênica) ou ao afrouxamento moral como forma

$\langle$ http://portal.mec.gov.br/index.php?option=com_content\&task=view\&id=9885>. Acesso em 07/12/2014.

${ }^{11}$ Para maiores detalhes sobre as mudanças na reforma da educação consultar Ball (2002). 
de sobreviver dentro do sistema educativo (através da adoção de estratégias de subversão/adaptação - quando possíveis). Nos casos de conflito extremo de convicções, há o abandono da carreira no magistério.

O mal-estar da escola, atribuído genericamente aos baixos índices de rendimento dos alunos em exames, é transferido nas formas de culpa e prejuízo, aos professores que não alcançaram suas metas de produção, que não souberam controlar e regular suas atividades, mas isenta os gestores públicos que cumprem seu papel de fomentar o serviço e fiscalizá-lo em busca da otimização dos recursos. A performatividade é tão perniciosa porque altera a forma de conceber a natureza da escola e dos professores e suas relações com a sociedade.

Este seria um novo conjunto regulador, menos visível, que pretende transformar os professores em sujeitos empresariais, que incorporariam uma empresa do "eu" (...) Convém observar que a insistência em tornar os resultados (entendidos como indicadores de qualidade) mais transparentes, dando-lhes maior visibilidade, ocorra paralelamente à implantação de formas de regulação da educação mais invisíveis. (SHIROMA, 2004, p. 114, grifo da autora)

Shiroma (2004) continua sua argumentação ao relacionar a profissionalização do quadro do magistério aos documentos e leis implementados no Brasil em meados dos anos 1990, tais como: o Plano Nacional de Qualificação Profissional (PLANFOR), a reforma da Educação Profissional e a promulgação da lei 9.394/96 (LDB) que consagrou a expressão "profissionais da educação". A influência de organismos internacionais, tais como o Banco Mundial, a Organização das Nações Unidas para a Educação, a Ciência e a Cultura (UNESCO) e a Organização Internacional do Trabalho, é verificada pela autora ao analisar documentos dessas instituições e resultados de estudos que apontam a profissionalização como política de regulação do trabalho docente.

À centralidade que se atribuía à educação, por esses documentos e organizações, como fator de desenvolvimento à modernização dos países que não dispunham das condições de participar da economia globalizada, foram sugeridas "profundas transformações nas orientações educativas a fim de conjugar crescimento com produtividade e mudança institucional, nesse caso, reforma do Estado.” (SHIROMA, 2004, p. 115) O que vai ao encontro da fala de Libâneo (2012, p. 15), ao analisar as repercussões das proposições da Conferência Mundial 
Sobre Educação para Todos, realizada em 1990, nas políticas públicas para a educação básica no Brasil, praticadas desde então:

(...) o impacto negativo, nos objetivos e nas formas de funcionamento interno das escolas, das políticas educacionais de organismos internacionais, as quais se transformaram em cartilhas no Brasil para a elaboração de planos de educação do governo federal e de governos estaduais e municipais, afetando tanto as políticas de financiamento, quanto outras como as de currículo, formação de professores, organização da escola, práticas de avaliação etc. (grifo do autor)

Como contraponto, temos a argumentação de Oliveira (2007): embora as reformas tenham sofrido influência de uma agenda mundializada, cada país as realizou de maneira diferenciada, em função de suas trajetórias políticas e histórias específicas. O autor concorda com Luiz Antônio Cunha que afirma: “(...) as reformas empreendidas no Brasil são resultado de árduo conflito, público ou mesmo intramuros à burocracia educacional, mas não seguem uma dada 'cartilha'." (CUNHA, 2002 apud OLIVEIRA, 2007, p. 664). Dessa forma o autor relativiza o perfil estritamente neoliberal das reformas implantadas no Brasil, bem como o ditame das organizações internacionais, mas reconhece o isolamento e a competitividade profissionais como características projetadas na carreira docente.

De acordo com Shiroma (2004) a noção de profissionalizar foi utilizada nos processos de reforma do ponto de vista de seu significado no senso comum, qual seja, uma necessidade de capacitação em alusão a maiores competência e autoridade e em oposição ao amadorismo. A autora apresenta um debate entre autores de abordagem funcionalista para os quais o desenvolvimento é alcançado pela intervenção profissional e pelo princípio da racionalização ou racionalidade, empregado amplamente nas reformas gerencialistas. Esse princípio ou modelo é reconhecido por Schön (1983, p. 21 apud DINIZ-PEREIRA, 2011, p. 45) quando "a atividade profissional consiste na solução instrumental de um problema feita pela rigorosa aplicação de uma teoria científica ou uma técnica".

A perspectiva da racionalidade técnica assumiu o protagonismo de uma nova identidade ou perfil docente, à medida que estratifica o trabalho dos profissionais da educação, distanciando o professor de concepções pertinentes ao seu trabalho, como exemplos, as discussões curriculares, a elaboração dos métodos avaliativos e a autonomia para selecionar e produzir materiais pedagógicos. Há reflexos ainda na formação sob a alegação de que não se faz 
necessário tanto tempo dedicado aos pressupostos teóricos, basta que o professor aplique um conjunto predeterminado de práticas ditadas pela eficiência que os estudantes adquirem um conjunto de competências - o que configura a proletarização da profissão e a precarização do trabalho, bem como a diminuição da escolarização como atividade intelectual.

Ao situar a degradação do estatuto socioprofissional dos professores em Portugal, Nóvoa (1995) apresenta a proletarização como processo antagônico da profissionalização. O autor apresenta uma síntese de Ginsburg (1990, p. 335 apud NÓVOA, 1995, p. 24) sobre a proletarização da profissão docente:

provoca uma degradação do estatuto, dos rendimentos e do poder/autonomia; é útil sublinhar quatro elementos deste último processo: a separação entre a concepção e a execução, a estandardização das tarefas, a redução dos custos necessários à aquisição da força de trabalho e a intensificação das exigências em relação à atividade laboral.

Diniz-Pereira (2011) argumenta ainda que as políticas públicas educacionais têm grande responsabilidade na construção e perpetuação de uma representação social desprestigiada e inferiorizada da identidade do professor, "uma vez que a valorização do profissional da educação não consegue ir além de um discurso demagógico, que não se traduz em melhorias efetivas nas condições salariais e de trabalho dos professores" (DINIZ-PEREIRA, 2011, p. 47). A mesma questão já era apontada por Brzezinski e Garrido (2001), quando comentam o impacto das políticas neoliberais sobre a formação docente e a gestão dos sistemas educacionais: “A profissionalização do professor é entendida como produtora de resultados eficientes, aferidos basicamente pelo desempenho do alunado nos exames nacionais.” (BRZEZINSKI; GARRIDO, 2001, p. 90).

Libâneo (2012) apresenta argumentos semelhantes ao associar uma “formação aligeirada de um professor tarefeiro, visando baixar os custos do pacote formação/capacitação/salário" (p. 20, grifo do autor) com uma nova função social específica da escola, "a socialização e a convivência social, colocando em segundo plano a aprendizagem dos conteúdos” (p. 22). O autor discorre sobre a perversidade e dualismo que a educação pública brasileira vive ao oferecer uma 
escola do conhecimento para os ricos e uma escola do acolhimento social para os pobres $^{12}$.

O texto de Morgado (2011) sumariza uma série de questões já abordadas e costura as premissas tomadas ao propor um estudo com os professores iniciantes. $\mathrm{O}$ autor elabora sua argumentação sobre a profissionalização, ou o desenvolvimento profissional, como um processo contínuo de formação e aprendizagem ao longo da carreira docente, a partir do desenvolvimento de competências ou saberes profissionais, apropriação de uma dada cultura profissional e assim a construção da identidade profissional (apropriação de valores e práticas característicos) - argumentos discutidos com base nos trabalhos de Day, Roldão e Tardif e Lessard. O autor concorda que a formação profissional "é um processo tanto de especialização como de socialização (...) através da qual o candidato ao exercício da profissão aprende uma postura profissional (ethos)" (MONTEIRO, 2009, p. 49 apud MORGADO, 2011, p. 797). Ele também apresenta o conceito de profissionalidade docente "aquilo que é específico na acção docente, isto é, o conjunto de comportamentos, conhecimentos, destrezas, atitudes e valores que constituem a especificidade de ser professor" (GIMENO SACRISTÁN, 1985, p. 64 apud MORGADO, 2011, p. 798).

A utilização de diferentes, mas complementares, referenciais teóricos se encaixa no momento de reformas educacionais e das novas exigências colocadas para a atuação do professor. Morgado (2011) argumenta que as mudanças recentes geram efeitos negativos sobre a identidade e a profissionalidade docente, tais como: sobrecarga de trabalho, perda de confiança, sensação de incompetência e culminam remetendo os professores a meros transmissores de conteúdos, desprovidos da autonomia e reflexividade. O autor afirma que a formação de professores deve se centrar no campo de atuação destes, a escola, e que esta deve se focar na formação dos professores:

Só assim se conseguirá envolver toda a instituição numa lógica aprendizagem e romper com uma certa "liturgia formativa" mais tradicional, que insiste em formar profissionais mais para o terreno da execução do que para os domínios da decisão e da inovação (MORGADO, 2011, p. 808).

\footnotetext{
${ }^{12}$ Para maiores detalhes consultar Libâneo (2012).
} 
A noção de profissionalização é entendida como "o processo socializador de aquisição de características inerentes ao exercício profissional, estando estritamente ligada ao termo profissionalidade, ou seja, como as características e capacidades específicas da profissão docente" (IMBERNÓN, 2004, p. 24 apud NETO; BENITES; SILVA, 2010, p. 1034). Corrobora-se com a afirmativa de que “a profissão de professor, como as demais profissões, emergiu num dado contexto como resposta às necessidades postas pelas sociedades, constituindo-se num corpo organizado de saberes e um conjunto de normas e valores" (BENITES, 2007, p. 10 apud NETO; BENITES; SILVA, 2010, p. 1035).

Alves e André (2013) também esboçam uma revisão sobre o conceito de profissionalidade e descrevem uma investigação realizada com professores da educação básica, que objetivou compreender os possíveis efeitos dos indicadores de qualidade na constituição da profissionalidade docente, na qual utilizaram os descritores da profissionalidade propostos por Roldão (2005): o reconhecimento social da especificidade da função, a existência de um saber específico, o poder de decisão sobre o trabalho desenvolvido e a pertença a um corpo coletivo. Roldão (2005) elenca esses elementos a partir das contribuições de Gimeno Sacristán, Claude Dubar e António Nóvoa.

A apresentação desses quatro descritores ou caracterizadores do trabalho docente é feita de modo a tensionar o entendimento da atividade e identidade do professor segundo a perspectiva de profissionalização e da discussão sobre o conceito de 'ensinar' (ROLDÃO, 2005) - debate similar à feita no Brasil por Marin (1996). Sobre as dimensões de poder e controle dos professores sobre a ação docente, a autora afirma que há restrições, “o que constitui uma das limitações sérias ao estabelecimento social do seu estatuto como profissionais plenos" (ROLDÃO, 2005, p. 111). Além disso, aponta "o esvaziamento de um corpo colectivo, enquanto comunidade de pares" (p. 113), gerado pela tendência de individualismo no exercício da profissão, e "a ideia de que ser professor é relativamente fácil desde que se 'saiba' a matéria e se consiga 'controlar' os alunos" (p. 114), como indicativos de uma profissionalidade não estabelecida. Roldão afirma existir uma generalizada representação do senso comum, a partir desses elementos, os quais também podem ser observados no Brasil.

O entendimento de profissionalidade segundo Roldão (2005) se aproxima da definição feita no Brasil por Lüdke e Boing (2010) e da recente proposição dos 
referentes de ação docente feita por Silva e Almeida (2015). A preferência pelo conceito na abordagem da construção profissional do professor deve-se à valorização dos aspectos pessoais-afetivos, das trocas e aprendizados colaborativos entre os pares nos locais de trabalho e o entendimento da formação para a docência como um processo contínuo ao longo de várias etapas da vida (que abrangem a formação e a reflexão para/sobre o trabalho). Tal como Contreras (2012), evitar o termo profissionalismo e ir contra a retórica de profissionalização nos discursos oficiais é assumir postura crítica à presunção do status profissional decretado e aspirado pelos trabalhadores do ensino: "Em seu lugar, optou-se pelo termo profissionalidade, como modo de resgatar o que de positivo tem a ideia de profissional no contexto das funções inerentes ao trabalho da docência" (CONTRERAS, 2012, p. 82).

Almeida (2010), seguindo caminho similar ao de Dubar (1997) e Barbosa (2003), ao analisar as principais contribuições teórico-metodológicas da Sociologia das Profissões (nas vertentes funcionalista e interacionista) nos possibilita pensar a atividade docente à luz dos argumentos morais dos grupos profissionais de Durkheim; nos atributos laborais e formativos, ou "termos de profissionalização", descritos por Carr-Saunders e Wilson; do papel social da profissão e do estatuto profissional abordados por Parsons e Goode; considerando as circunstâncias sócio históricas e as condições estruturais (como a divisão do trabalho e a transferência de legitimidade pela sociedade) apontadas por Nóvoa e Hughes e as contradições e interesses do processo de profissionalização discutido por Freidson, Larson e Abbott.

A apreensão das análises e discussões propostas por esses autores ${ }^{13}$ nos leva a pensar e repensar a construção da identidade dos professores e sua temporalidade, especialmente diante da crise ou mal-estar docente, como sugerido por alguns autores, que se sucede em decorrência das reformas administrativogerencialistas nos sistemas de ensino e aquelas relativas à formação inicial dos professores. A esse respeito, Cunha (1999, p. 141) propõe que:

\footnotetext{
${ }^{13}$ Uma análise mais detalhada das muitas definições e correntes teóricas da sociologia das profissões vinculada às representações sobre a profissão docente é um encaminhamento de continuidade dessa pesquisa.
} 
Esse mal-estar poderia ser caracterizado como uma sensação de frustração psicológica ou física decorrente das condições de trabalho precárias, da falta de valorização social e da crise de identidade profissional. Essas condições podem ser entendidas como extrínsecas e se somam às de natureza intrínseca, como a ansiedade, a insegurança e a instabilidade vividas pelo professor num contexto que, cada vez mais, lhe faz exigências e lhe impõe uma sobrecarga de trabalho.

A ponderação sobre o trabalho docente estar no "decurso de um processo de profissionalização não concluído”, como sugere Dubar (1997, p. 131), faz-se necessária. $\mathrm{O}$ autor considera a contribuição de Chapoulie sobre a imprecisão do termo profissão, a falta de domínio de saberes legítimos ("científicos" e não apenas práticos) e ainda a não constituição de uma comunidade profissional autônoma. Mesmo o conjunto de conhecimentos específicos da carreira não lhe é próprio mas se não emprestado por outras áreas de pesquisa. Hughes (apud DUBAR, 1997, p. 135) assinala que "qualquer profissão tende a constituir-se em grupo de pares com o seu código informal, as suas regras de seleção, os seus interesses e a sua linguagem em comum e a segregar estereótipos profissionais". Vargas (2013) indica os grupos profissionais como detentores da capacidade de influenciar as distinções e a hierarquia do mundo social como um todo. A autora afirma que as corporações profissionais (conselhos e associações) contribuem para o fortalecimento das carreiras que representam nos níveis institucional, salarial, simbólico, político e de mercado, e o fechamento ${ }^{14}$ da profissão. Para o caso específico da carreira docente ${ }^{15}$, Vargas (2013, p. 247) afirma que

a ausência de uma instituição equivalente a conselho ou ordem, à semelhança do que ocorre nas carreiras imperiais (...) está possivelmente na raiz do declínio da profissão de professor, bem como na má qualidade da formação de nossos alunos, situações amplamente constatadas pelos militantes da docência em nosso país.

De acordo com as ponderações desses autores, a não consolidação de um conselho, associação profissional ou coletivo que atue junto ao Estado na regulação da atividade profissional, da formação inicial e contínua, congregando

\footnotetext{
${ }^{14}$ Uma vez que o termo reaparece na análise das representações dos respondentes dessa pesquisa, reproduz-se a nota de rodapé de Vargas (2013, p. 244): "O conceito de "fechamento" foi elaborado por Max Weber, para indicar o processo pelo qual coletividades sociais procuram maximizar seus ganhos pela restrição do acesso a recursos e oportunidades, geralmente de natureza econômica, a um círculo limitado de escolhidos que buscam monopolizá-los".

${ }^{15}$ Para maiores detalhes sobre pertinência de um conselho ou ordem para a carreira docente, frente a desvalorização e o desprestígio do magistério, consultar Vargas (2013).
} 
ainda as lutas por melhores condições de trabalho, carreira e reconhecimento social, sugerem uma fragilidade no status do magistério/docência como profissão. Hughes, como aponta Dubar (1997), coloca a socialização profissional no centro da análise das realidades de trabalho e no foco da discussão sobre profissionalidade. Tal proposta é ilustrada com os achados de uma pesquisa realizada por Lortie (apud DUBAR, 1997, p. 138) com juristas recém-formados:

os estudos os preparam mal (dois terços dos casos), (...) os exercícios práticos e as capacidades sociais são muito mais importantes do que os "conhecimentos" para exercer o ofício (...) as transformações importantes da sua personalidade aconteceram por ocasião da imersão no mundo do trabalho depois de terem obtido o seu diploma.

Apesar da pluralidade lexical e semântica, bem como das características atribuídas para a profissão docente, há uma contradição na definição de suas especificidades e finalidades laborais. Nesse sentido, Guimarães (2006, p. 138) afirma que "Como se pode notar, profissionalização, socialização profissional, desenvolvimento profissional e construção de identidade profissional são conceitos conexos. Dependendo do enfoque, podem ser quase indistintos.”. O autor relembra as proposições de Eliot Freidson e Philippe Perrenoud que consideram a docência, respectivamente, uma semiprofissão e uma atividade em vias de profissionalização.

A regulação da profissão não é feita por aqueles que são cobrados a executar as propostas educacionais e a cumprir as determinações sobre o ensino, centrado no papel do professor. Tal como discutido por Sarti (2012, p. 332), em analogia ao modelo de análise proposto por Nóvoa (1999), os professores "atuam como o morto no jogo da formação docente, um referencial passivo para os demais jogadores cuja existência, no entanto, possibilita todas as jogadas". A autora observa como o poder público e as universidades, dois vértices do triângulo da formação docente ${ }^{16}$, estabelecem relações privilegiadas sobre a formação e a regulação da profissão docente, deixando o professor à margem do processo de profissionalização.

As especificidades e finalidades são decididas à sua revelia, o que nos permite questionar seu status ou estatuto profissional, quando comparada àquelas 
profissões que por razões históricas têm maior controle sobre si e seus membros. De fato, a institucionalização do magistério e sua legitimação social fizeram essa ocupação emergir e se aproximar da categoria de profissão, mas sua evolução histórica - como sugerido por Freidson e Perrenoud ${ }^{17}$, como uma atividade transitória e secundária na composição da renda, marcada pela feminização e pela dependência de conhecimentos de outras áreas - levam a questionar se o processo de profissionalização da mesma atingiu o patamar das profissões liberais e mais antigas. Ainda que a identidade profissional do professor seja algo em construção e viva mudanças desde meados do século XIX, ao longo desse tempo, muitos ganhos trabalhistas e algum desprestígio social afetaram o lugar e a atratividade dessa ocupação na hierarquia da divisão social do trabalho.

O conceito de profissionalização do magistério precisa ser problematizado, então, no âmbito da consolidação de um estatuto e de uma autonomia profissionais: estabelecimento de contornos para a formação, condições de trabalho, garantia de remuneração condizente, jornada de trabalho e vinculação dos trabalhadores à associações e sindicatos. E como pondera Contreras (2012 p. 74) “a profissionalização atua como modo de garantir a colaboração [dos professores] sem discutir os limites de [sua] atuação". Em que medida os professores, influenciam e contribuem na sua formação, atuação e regulação da profissão? Eles continuam alheios das tomadas de decisão para definição e o desenvolvimento da profissão e na reivindicação de suas competências específicas, aspectos apontados pela sociologia das profissões que conferem o estatuto profissional para uma determinada atividade.

Dessa forma, é possível reconhecer a importância dos saberes e aprendizados advindos da prática e da troca com seus pares, em contextos de trabalho. Conferir autonomia ${ }^{18}$ não é igual a participar do controle sobre a formação e avaliação do desempenho profissional. Legitimidade social é outro

\footnotetext{
${ }^{16}$ Para maiores detalhes sobre o modelo e suas configurações consultar Sarti (2012).

17 As obras de Lortie (1975), Freidson (1998) e Perrenoud (2001), embora não consultadas, constituem pontos de partida para discussões mais aprofundadas sobre a profissionalização docente e a compreensão das mutações e permanências sobre o trabalho docente. Em virtude do curto tempo disponível no Mestrado, optou-se por indicar a contribuição dos autores para estudos subsequentes.

18 A proposição de Barroso (1996) por uma autonomia construída em oposição a uma autonomia decretada, baseada por uma "cultura de colaboração e participação", mostra-se mais condizente com a profissionalização e constituição de um grupo profissional de professores.
} 
ponto contraditório, já que se observa cada vez mais desinteresse pela profissão em vistas de seu baixo retorno salarial e alta carga de efetivo trabalho. $\mathrm{O}$ alto grau de desestímulo, pouco ou nenhum reconhecimento e as difíceis condições para realização de um trabalho sustentável, perante o compromisso ético com os objetivos educacionais, são frequentemente apontados por aqueles que abandonam a profissão ou buscam outra atividade de sustento, bem como por jovens que não enxergam possibilidades de concretizar realização e estabilidade na carreira.

\section{3. \\ Desenvolvimento profissional docente}

Ao tomarmos o entendimento da profissão docente como um "espaço social” (BOURDIEU, 1989), há que se concordar com a tese do desenvolvimento profissional contínuo, que ocorre ao longo da vida dos sujeitos ou agentes que buscam se inserir no campo educacional. Isso implica reconhecer a incorporação de disposições, duráveis e flexíveis, desenvolvidas pela aprendizagem, mas não mecânicas nem determinísticas (cf. THIRY-CHERQUES, 20006), e uma estrutura de capitais, a partir dos quais os iniciantes se integram ao campo escolar e desenvolvem formas de agir pertinentes à sua posição de iniciantes e se relacionam com os pares, inclusive os mais experientes. Como pontua Papi (2011a, p. 79) “A percepção do caráter determinante das condições objetivas não deve levar, entretanto, ao entendimento de que o campo de possibilidades da ação humana fica restrito ao que é regido por essas condições".

Bourdieu sugere que no espaço social há uma ambiguidade intrínseca nas ações dos agentes entre a manutenção e a ruptura das regras que sustentam o jogo social. O autor afirma que a noção de campo auxilia a verificar que um objeto de análise "não está isolado de um conjunto de relações de que retira o essencial das suas propriedades" e, por isso, "é preciso pensar relacionalmente" (BOURDIEU, 1989, p. 27-28). Dessa maneira, compreender a profissão como um campo, permite enxergar as posições e significados expressos pelos agentes que nele adentram e circulam. Tanto as contradições quando as condições objetivas são influências para o processo identitário.

Ainda que esta pesquisa busque alguma objetivação de sentimentos e experiências sobre a entrada na profissão docente, a abertura do olhar para as 
subjetividades identificadas parcialmente na revisão empírico-teórica foi fundamental para a construção de um instrumento de pesquisa que englobasse tais variáveis e permitisse conhecer algumas das representações daquilo que foi e é vivido pelos professores em início de carreira no cotidiano de suas atividades profissionais. As noções de campo e habitus são particularmente úteis para entender as estruturas objetivas e o conjunto de valores e princípios intrínsecos de um dado contexto social.

O habitus gera uma lógica, uma racionalidade prática, irredutível à razão teórica. É adquirido mediante a interação social e, ao mesmo tempo, é o classificador e o organizador desta interação. É condicionante e é condicionador das nossas ações. (...) Os habitus não designam simplesmente um condicionamento, designam, simultaneamente, um princípio de ação. Eles são estruturas (disposições interiorizadas duráveis) e são estruturantes (geradores de práticas e representações). (THIRY-CHERQUES, 2006, p. 33, grifos meus)

Nesse sentido, Marcelo ${ }^{19}$ (2009) entende o desenvolvimento profissional docente pelo compromisso de transformar conhecimentos e saberes em aprendizagens relevantes para os alunos. Segundo este autor, da mesma forma que outros profissionais, os professores devem constantemente ampliar e aprofundar sua competência profissional e pessoal. Portanto, faz-se necessário superar a cisão entre programas de formação de professores "impregnados de concepções diferentes do professor" (MARCELO GARCÍA, 1995) e delimitados temporal e epistemologicamente, não raro, sem pontes, isolados em si mesmos, por um caráter tradicionalmente individualista. $\mathrm{O}$ autor propõe com $\mathrm{o}$ termo desenvolvimento uma compreensão global, ou uma atitude permanente, de investigação e busca de soluções para os problemas que se apresentam na prática de ensino, aquela que mobiliza o "conhecimento de conteúdo pedagógico" próprio da profissionalidade do professor.

Apoiando-se na contribuição teórica e proposta de abordagem do tornar-se professor feita por Donald Schön, o autor sustenta que na profissão professor “a própria prática conduz necessariamente à criação de um conhecimento específico e ligado à acção, que só pode ser adquirido através do contacto com a prática, pois trata-se de um conhecimento tácito, pessoal e não sistemático"

\footnotetext{
${ }^{19}$ Informo ao leitor que Carlos Marcelo García, professor na Universidade de Sevilha na Espanha, é autor de ambos os seguintes textos: Marcelo (2009) e Marcelo García (1995).
} 
(MARCELO GARCÍA, 1995, p. 60). A reflexão na ação não está isenta de fundamentação das teorias da educação, acessadas pelos professores pela formação específica no curso de licenciatura, e se dá quando "O conhecimento prático pessoal implica um ponto de vista dialéctico entre a teoria e a prática" (SCHÖN, 1986, p. 20 apud MARCELO GARCÍA, 1995, p.60, grifo meu).

O autor, em publicação mais recente (MARCELO, 2009), relaciona o conceito de desenvolvimento profissional ao de construção do eu profissional ou da identidade profissional, aquilo que define a si mesmo e aos demais professores. Ao considerar o desenvolvimento da identidade no plano da intersubjetividade e da contextualização de locais de trabalho, o autor chama a atenção para importância da autonomia desses profissionais no exercício do seu trabalho. E recupera o clássico estudo de Lortie (1975) sobre a socialização dos professores para enumerar as críticas e problematizar o grau de influência que a formação inicial têm ou não na constituição da profissionalidade docente, frente um sistema de crenças acerca do ensino, advindas de suas trajetórias enquanto alunos.

Marcelo García (1995) também aborda a importância da identificação das necessidades formativas dos professores iniciantes (dúvidas e necessidades relativas aos alunos, ao currículo, às funções e papéis do professor e aquelas referentes à escola), a fim de facilitar o período de "intensa aprendizagem" marcado pelo "choque de realidade" (VEENMAN, 1984). Além de indicar um programa de mentoria, onde um professor com larga experiência apoia e supervisiona o iniciante, o autor sugere que o diagnóstico dessas necessidades sejam integrantes de um processo de avaliação dos programas de formação. Aponta ainda o diálogo entre colegas da mesma profissão como estratégia para romper o isolamento do professor e o estudo de casos como alternativa teóricometodológica para o desenvolvimento da análise crítica e a resolução de problemas, lidar com as expectativas e os comportamentos dos alunos e a cobrança da sociedade para que se alcancem os objetivos/metas da escola (cf. Guarnieri, 2008).

A representação mais abstrata dos problemas do cotidiano e a complexidade das competências docentes são apontadas por Bereiter e Scardamalia (1986 apud MARCELO, 2009) como características ligadas à experiência e ao tempo de atuação, ao longo do qual os professores desenvolvem uma "perícia" sobre as suas aprendizagens. Marcelo (2009) associa essas características à mudança de crenças 
e à desconstrução de preconceitos que os professores iniciantes carregam na entrada do seu percurso profissional. Apoia-se novamente em Lortie (1975) para relacionar o "aprender a ensinar" através da "aprendizagem por observação", "que não se gera de forma intencional, mas vai penetrando, de forma inconsciente, as estruturas cognitivas - e emocionais" (MARCELO, 2009, p. 15). Professores peritos, em comparação a professores iniciantes, utilizam crenças, vinculadas a emoções e experiências, como filtros para recuperar o conhecimento e os saberes da prática. A tese se aproxima, portanto, de uma atividade do tipo ofício, embora não invalide a importância da formação específica, pelo contrário, amplia o entendimento de formação, incluindo a reflexão sobre a prática que conduz a novas aprendizagens e são constitutivas do se tornar professor (GUARNIERI, 2008).

A proposição de um habitus professoral, conjunto de condutas e pensamentos que identificam um grupo enquanto profissionais do ensino (cf. TOWNSEND; TOMAZZETI, 2007) toma relevo pela emergência de características e comportamentos, que foram e são internalizados e externalizados no cotidiano escolar, na e sobre as práticas pedagógicas e em função das trajetórias formativas dos sujeitos (cf. SILVA, 2011). A autora sugere que o habitus professoral, próprio do exercício profissional do professor, deveria ser igualmente privilegiado na formação universitária quando na prática supervisionada do estágio, o qual oriente o "ensino real na sala de aula".

Essa afirmativa deve ser tomada com alguma ressalva uma vez que habitus não é sinônimo de saberes docentes, trata-se de um conjunto de disposições práticas, um "senso prático" do jogo social, algo não-consciente para os indivíduos ao longo de suas vivências e socialização. A mobilização de conhecimentos pelos professores no planejamento e execução de atividades didático-pedagógicas, são manifestações de um conjunto de saberes específicos da profissão. A naturalização destes para a tomada de decisões e ajustes na condução do processo de ensino-aprendizagem advém da formação, da reflexão sobre a prática e do comprometimento ético com a ocupação.

O habitus como sentido do jogo é jogo social incorporado, transformado em natureza. Nada é simultaneamente mais livre e mais coagido do que a ação do bom jogador. (...) O habitus como social inscrito no corpo, no indivíduo biológico, permite produzir a infinidade de atos de jogo que estão inscritos no jogo em estado 
de possibilidades e de exigências objetivas; as coações e as exigências do jogo, ainda que não estejam reunidas num código de regras, impõem-se àqueles e somente àqueles que, por terem o sentido do jogo, isto é, o senso da necessidade imanente do jogo, estão preparados para percebê-las e realizá-las. (BOURDIEU, 2004, p. 82)

Nascimento (2012) propõe que a realidade de trabalho, em especial nos primeiros anos da carreira, constitui condição objetiva na qual as disposições e os conhecimentos adquiridos nas socializações anteriores (familiares, escolares e na formação em nível superior) sofrem ajustes e uma reestruturação a favor de um habitus profissional. Ao investigar a socialização profissional de professores iniciantes articulada à organização escolar, Freitas (2002) observou que há uma distinção conferida pelo tempo de exercício e que este agrega simbolicamente a superação das dificuldades encontradas e o desenvolvimento de estratégias de admissão e reconhecimento. Por fim, Oliverio (2014) caracteriza subcampos educacionais em função da dependência administrativa do local de inserção do professor iniciante e discute que as dificuldades enfrentadas e as estratégias mobilizadas são elaboradas de acordo com as especificidades de cada subcampo, mas fazem parte de um conjunto de disposições que caracterizam o trabalho docente.

Nesse entendimento, habitus é "construído continuamente, aberto e constantemente sujeito a novas experiências (...) predispõe à reflexão e a uma certa consciência das práticas" (SETTON, 2002, p. 65) e campo "são 'espaços estruturados de posições' em um determinado momento [e que] podem ser analisados independentemente das características de seus ocupantes" (THIRYCHERQUES, 2006, p. 36). O trabalho de Setton (2009), parte do conceito de fato social total de Marcel Mauss para problematizar as críticas de Bernard Lahire sobre a teoria do habitus e indica que a obra de Bourdieu é fundamental para se compreender a formação da identidade pessoal e grupal dos indivíduos na contemporaneidade. A autora afirma que "é um conceito, e assim deve ser circunstanciado historicamente, conceito que expressa a mediação indivíduosociedade; é princípio explicativo das práticas e das representações de indivíduos em conjunturas específicas e particulares" (SETTON, 2009, p. 304, grifos meus), portanto indispensável em pesquisas que visam apreender a dinâmica do campo da socialização profissional. 
A flexibilidade do conceito de habitus, por serem "operadores de distinções" (BOURDIEU, 2008) e pelo seu caráter praxiológico com o conceito de campo levam ao reconhecimento de interesses e estratégias:

A existência de um campo especializado e relativamente autônomo é correlativa à existência de alvos que estão em jogo e de interesses específicos: através dos investimentos indissoluvelmente econômicos e psicológicos que eles suscitam entre os agentes dotados de um determinado habitus, o campo e aquilo que está em jogo nele (eles próprios produzidos enquanto tal pelas relações de força e de luta para transformar as relações de força constitutivas do campo) produzem investimentos de tempo, de dinheiro, de trabalho, etc. (BOURDIEU, 2004, 126127)

Quanto maior a incorporação de disposições específicas e a adaptação à conjuntura do jogo social, mais os agentes tendem a naturalizar suas estratégias de inserção e pertencimento, o que não significa que sejam racionais, conscientes ou disparatadas (cf. BOURDIEU, 2008). Assim, “é no confronto com os espaços sociais e as atividades regradas desses espaços que o professor vai se constituindo como docente" (OLIVERIO, 2014, p. 48). O que leva à proposição de Lelis (1996) sobre um capital pedagógico. A autora evidencia, pela pluralidade de trajetórias, representações e realidades vividas pelos professores ao longo do tempo de trabalho, a aquisição de um capital simbólico que antes não possuíam: "A dimensão didática do trabalho que desenvolvem se relaciona com outras esferas de suas vidas [e] aparece sob a forma dos recursos didáticos usados" (LELIS, 1996, p. 157).

A autora propõe a leitura de modos de trabalhar, segundo posições no campo profissional marcadas pelos distintos volumes e estruturas de capitais obtidos pelos professores ao longo das socializações primária e secundária, na formação em nível superior e ainda nos demais espaços sociais que transitam. Por capital, entende-se "o conjunto de recursos atuais ou potenciais que estão ligados à posse de uma rede durável de relações mais ou menos institucionalizadas de interconhecimento e de inter-reconhecimento" (BOURDIEU, 2014, p. 75). O investimento e a conversão de capitais variados e específicos, do ponto de vista pedagógico, "permite[m] aos professores maior desenvoltura e pertinência em suas ações (...) em torno das preocupações com a pertinência de suas ações junto aos estudantes que os professores concebem a coerência de sua atuação" (NETO; SARTI; BENITES, 2012). 
A prática reflexiva, a ação deliberativa, a superação da simplificação da atividade docente e a criação de um ambiente de trabalho em grupo e de colaboração entre os professores são propostas por Marcelo García (1995) em torno do conceito de desenvolvimento profissional e pessoal, pela incorporação de um habitus professoral e a mobilização de um capital pedagógico. Por sua vez, vão ao encontro de uma "nova" profissionalidade docente que propõe Nóvoa (1995, p. 24), a partir da qual é estimulada "a emergência de uma cultura profissional no seio do professorado e de uma cultura organizacional no seio das escolas" e de uma autonomia profissional construída como propõe Barroso (1996, p. 170) "através de um processo de reconhecimento das formas de autonomia emergentes no funcionamento das escolas, nas estratégias e na acção concreta dos seus atores". 


\section{3 Jornada teórico-metodológica}

Brandão (2010) propõe e exemplifica uma forma de fazer pesquisa que coloque em "jogo as coisas teóricas" na perspectiva de que "no social tudo é relacional". Os ensinamentos de Pierre Bourdieu buscam trabalhar teoria e empiria numa relação de constante troca e reflexão. A autora alerta com perspicácia para a necessidade de interlocução a fim de evidenciar o que se ganha ou perde com as opções teórico-metodológicas que orientam um determinado projeto de investigação, bem como de se evitar a supremacia dos referenciais teóricos e desvalorização das análises e a problematização sobre o objeto analisado.

Nessa lógica, o enquadramento do objeto é produzido de forma a permitir perceber a sua posição relativa no conjunto de objetos semelhantes, o que possibilita avaliar, de forma mais acurada, o seu sentido (valor, significado, pertinência) em uma determinada configuração do social. (BRANDÃO, 2010, p. 229)

Para pensar a construção da identidade profissional, faz-se necessário coadunar as representações individuais com os contextos de trabalho, considerar as questões relativas à burocracia e regulação, problematizar a hierarquia das atividades laborais em função da divisão social do trabalho e das desigualdades sociais e reconhecer os saberes e aprendizados específicos da (para e na) prática de ensino como integrantes do desenvolvimento contínuo da profissão, como propõem Day (2001), Marcelo García (1995), Marcelo (2009), Schön (1992), Tardif (2002), entre outros, e a perspectiva de pesquisa sociológica dos trabalhos de Almeida (2010), Barbosa (2003), Brandão (2010) e de Karabel e Halsey (1997). Espera-se iluminar algumas questões relativas à inserção profissional dos professores iniciantes, que características e atitudes são requeridas e mobilizadas por eles para o exercício da profissão.

A pesquisa buscou identificar o que e como pensam os professores em início de carreira sobre a formação inicial para a docência e a entrada no mercado de trabalho de dois conjuntos de licenciados (aqueles egressos do curso de 
Pedagogia, conhecidos como professores generalistas, e aqueles egressos do curso de Ciências Biológicas, conhecidos como professores especialistas). Assim, propôs-se um estudo comparativo a fim de identificar convergências e divergências na profissão docente no âmbito da educação básica, isto é, professores que atuam junto à educação infantil e séries iniciais do ensino fundamental (formados na Pedagogia) e professores que atuam nas séries finais do ensino fundamental e no ensino médio (formados nas Ciências Biológicas). A atratividade docente, a (des)valorização profissional e a hierarquia interna entre os tipos de professores serão hipóteses de investigação.

Ao considerar o momento de consolidação da universalização do ensino fundamental e médio no país, que incluiu ao longo dos últimos 40 anos parcelas da população com pouco ou nenhum acesso aos bens culturais valorizados socialmente, direitos sociais e à cidadania; ao assumir o momento de ampliação do número de instituições e de vagas nos cursos de graduação, bem como os grandes investimentos públicos na formação em nível superior da população brasileira; e, ao considerar os incentivos para formação e qualificação profissional de docentes para atuarem na educação básica, a pesquisa está contextualizada com a grande demanda desses profissionais nos processos formais de ensino público e privado, além de alerta às inúmeras críticas, desafios e dificuldades do exercício profissional no magistério. Tomar ciência desses balizadores, alguns deles persistentes nos debates e investigações do campo educacional, é mister na produção de uma pesquisa sintonizada com questões atuais e prementes.

Assumir a realização de um estudo exploratório-descritivo assinala os limites temporais e metodológicos de realização da pesquisa, os cuidados com a não generalização e o não fechamento das questões de investigação e das análises. A descrição analítica pretende ir além do estudo descritivo, no sentido de identificar as homologias (BOURDIEU, 2004) das vivências de egressos de cursos de licenciatura (em Pedagogia e em Ciências Biológicas), colocando em perspectiva hipóteses e resultados de estudos anteriores, além de discutir conceitos teóricos relativos à profissão docente. Assim teoria e empiria deverão ser tratadas numa relação de reciprocidade, buscando ainda identificar que outras indagações podem ser feitas, quais lacunas permanecem abertas e que desdobramentos a pesquisa permite. 
A decisão por considerar e buscar entender a importância dos elementos das trajetórias de escolarização, formação e atuação no magistério para esses professores objetivou identificar como percebem a profissão docente através de múltiplas instâncias de socialização e da pluralidade de contextos de trabalho. No balanço entre singularidades e regularidades, buscou-se a "semelhança na diferença" como propõe Bourdieu (2004, p. 170).

O caráter exploratório (SELLTIZ et al, 1975) dessa pesquisa está no esclarecimento de alguns conceitos e na compreensão de como são vividas e percebidas as características de um processo. A abordagem descritiva (GIL, 2002; SELLTIZ et al, 1975) pretende conhecer as características, opiniões e atitudes de uma determinada população e apresentar a proporção de pessoas dessa população que se comportam de determinadas maneiras. A presente pesquisa utilizou um instrumento quantitativo de produção e análise dos dados, mas não deixará de considerar as relações e subjetividades dos participantes, uma vez que sua elaboração considerou os estudos existentes e os encaminhamentos/sugestões apontados pela revisão da literatura sobre o tema. Portanto, a quantificação exige antes um exercício de elaboração de categorias e variáveis qualitativas. Sobre a dicotomia quantitativa ou qualitativa da pesquisa em educação, Gatti (2002) afirma que é preciso considerar que tais conceitos não são totalmente dissociados,

na medida em que de um lado a quantidade é uma interpretação, uma tradução, um significado que é atribuído à grandeza com que um fenômeno se manifesta (portanto é uma qualificação dessa grandeza), e de outro ela precisa ser interpretada qualitativamente pois, sem relação a algum referencial não tem significação em si. (GATTI, 2002, p. 29)

A pesquisa de Lacerda (2000) é ilustrativa sobre os cuidados na elaboração de um questionário, que visa à objetivação de fatos sociais ao toma-los para análise estatística do tipo probabilística, abstraindo-se dos indivíduos e suas particularidades "e estar ciente de que penetrar no mundo social é penetrar no desconhecido" (LACERDA, 2000, p. 28). As regularidades evidenciam padrões de conduta e o conhecimento prático, o habitus dos agentes sociais. Inspirada por Bernard Lahire, a autora aborda a necessidade de preparar o olhar para se enxergar as variáveis e hipóteses como situações singulares e processuais, bem como manter em foco, diante do uso de um ou mais instrumentos de pesquisa, os limites artificiais "que a moldura do quadro impõem". 
Sobre a noção de comparabilidade, Lacerda (2000, p. 40) afirma que não basta comparar as práticas de um grupo com as de outro "o fundamental é entender como as práticas são usadas para distanciar ou aproximar essas pessoas das posições no jogo social". A reflexão é pertinente diante da expectativa de identificar as convergências entre dois grupos de licenciados e iniciantes no magistério acerca da profissão docente.

A construção do questionário visou, mormente, propiciar o acesso às informações que possibilitem a análise do tema e alcançar os objetivos apontados, para além de uma perspectiva ou quantitativa ou qualitativa: buscou-se uma apreensão da identidade profissional dos professores iniciantes, diante de seus pontos de vista nos contextos de trabalho, das relações que estabelecem e das posições e dos comprometimentos que informam na construção de suas carreiras.

De acordo com May (2004, p. 112), "Por que as surveys medem fatos, atitudes ou comportamentos por meio de questões, é importante que as hipóteses possam ser operacionalizadas em medidas". Tal operacionalização foi feita a partir do fundamental levantamento bibliográfico realizado, que forneceu achados, limites e lacunas de pesquisa.

Seguindo as orientações e exigências do Conselho Nacional de Saúde/Ministério da Saúde (CNS/MS), a partir da instância colegiada Comissão Nacional de Ética na Pesquisa (CONEP) e das resoluções ${ }^{20}$ pertinentes aos procedimentos de conduta de instituições e pesquisadores com a pessoaparticipante em investigações científicas, foi criado um Termo de Consentimento Livre e Esclarecido (TCLE), vide apêndice.

A CONEP foi estabelecida para examinar os aspectos éticos da pesquisa envolvendo seres humanos, bem como analisar os protocolos de investigações, a fim de garantir a eticidade, os direitos e deveres individuais e coletivos, promovendo o respeito ao outro, à dignidade humana e à cidadania. O TCLE objetiva informar e esclarecer às pessoas selecionadas para uma pesquisa acerca dos objetivos, procedimentos, riscos e benefícios, de modo que possam decidir-se por aceitar voluntariamente, ou recusar sua participação.

\footnotetext{
${ }^{20}$ Foram consultados os documentos: Resolução CNS/MS No 196/96 versão 2012, disponível em http://conselho.saude.gov.br/web_comissoes/conep/aquivos/resolucoes/23 out_versao_final 196 ENCEP2012.pdf e Resolução CNS/MS N N $^{\circ}$ 466, de 12 de dezembro de 2012, disponível em http://conselho.saude.gov.br/resolucoes/2012/Reso466.pdf.
} 
Como o envio dos questionários foi feito pela internet, o recebimento de respostas foi entendido como a concordância do participante, em substituição à assinatura do termo. Da mesma forma, a pesquisa foi submetida e aprovada pelo Comitê de Ética em Pesquisa da PUC-Rio, garantindo-se os interesses dos participantes da pesquisa em sua integridade e dignidade, e ainda de maneira a contribuir para o desenvolvimento da ciência dentro de padrões éticos.

\section{1.}

\section{A elaboração do questionário}

O questionário foi escolhido como instrumento para produção dos dados, a partir da definição do objeto de análise, ou pela "exigência do problema a investigar" (BRANDÃO, 2002, p. 28), e diante da distribuição dos participantes/informantes dessa pesquisa: pretendeu-se traçar um perfil dos egressos de dois cursos de graduação de uma universidade federal na cidade do Rio de Janeiro e conhecer os aspectos que caracterizam a profissionalidade dos licenciados/professores em início de carreira.

Isto posto, o questionário permitiu a criação de um banco de informações mais amplo do que o produzido por Pitta (2011), Reis (2011) - embora ambas tenham incluído aspectos de hábitos culturais dos respondentes que não foram privilegiados nessa pesquisa - e Souto e Paiva (2013) e assemelha-se ao elaborado por Bueno Ambrosini (2012) no tocante à questões epistemológicas dos saberes docentes, aos feitos por Alves, Azevedo e Gonçalves (2014) e Wzorek (2009) no que se referem à satisfação, desenvolvimento e motivação com o trabalho e, ainda, bom base nos roteiros de entrevistas de Furlan (2011) e Oliverio (2014) no que dizem respeito à profissionalidade docente (constituição da profissão e construção da identidade profissional). $\mathrm{O}$ argumento foi reunir mais informações e ensejar o contato estabelecido com os egressos, o qual é reportado na literatura ser relativamente difícil, e professores iniciantes.

A elaboração do questionário considerou a análise de estudos com egressos (PITA， 2011; BRANDALISE， 2012; SOUTO; PAIVA， 2013; ALVES; AZEVEDO; GONÇALVES, 2014; entre outros) e sobre professores iniciantes (MOURA, 1998; FREITAS, 2000, CORSI, 2005, FERREIRINHO, 2005; NONO; MIZUKAMI, 2006; CANCHERINI, 2010; REIS, 2011; FURLAN, 2012; 2014, 
entre outros) em articulação com os referenciais teóricos adotados, a fim de que as hipóteses fossem transformadas em perguntas objetivas e reflexivas, às quais os participantes da pesquisa fornecessem as informações necessárias para confirmálas ou refutá-las. Tal como Bueno Ambrosini (2012), as perguntas e sua sequência tinham a intenção de "fazer refletir e aflorar" nos sujeitos participantes sentimentos, dificuldades e aprendizados nos primeiros anos após a conclusão da formação obrigatória mínima para atuar como professor da educação básica.

"As contribuições para a criação da teoria podem ser conscientemente procuradas, ou podem ser mais ou menos acidentais. O cientista social, que intencionalmente procura desenvolver determinado aspecto de teoria, tende a seguir um programa de estudos relacionados, focalizados na questão pela qual está interessado. Em qualquer caso, é improvável que comece realmente do nada" (SELLTIZ et al, 1975, p. 553)

Assim a revisão da literatura e a definição do objeto e dos objetivos dessa investigação levaram à construção de um questionário autoaplicável que mescla questões fechadas de múltipla escolha (mais descritivas) e questões que utilizam escalas de concordância e relevância (perguntas interpretativas) com a escala de Likert $^{21}$. O esforço de padronização e a pertinência das questões, a clareza na redação dos itens, a ordenação das perguntas, o conhecimento sobre o público respondente são pontos destacados por Lacerda (2000) na construção do instrumento, para uma melhor da taxa de retorno e a obtenção de respostas que contribuam para a análise - a autora cita o exemplo de se evitar um elevado nível de respostas "outros" em questões de múltipla escolha que apresentem opções de resposta não satisfatórias.

Dessa maneira, as variáveis referentes à escolha da licenciatura, avaliação da formação, inserção no mercado de trabalho, motivações para qualificação profissional e abandono do magistério, características da profissão, envolvimento, desenvolvimento, desempenho, aprendizados e crenças sobre o trabalho docente consideraram as indicações teóricas, as hipóteses elaboradas e os achados e resultados de pesquisas empíricas realizadas sobre o tema.

A escolarização dos pais, a própria trajetória formativa, as motivações para entrada no curso de licenciatura, um ensaio de avaliação sobre a formação inicial

\footnotetext{
${ }^{21}$ Para maiores detalhes sobre escalonamento de variáveis consultar Babbie (2003).
} 
e a situação de emprego após a conclusão da graduação são elementos que compõem blocos de perguntas aos egressos. A concepção, inserção e satisfação em torno da profissão professor, a identificação de aprendizados e crenças sobre o trabalho docente e o comprometimento e envolvimento com o desenvolvimento pessoal e profissional compuseram questões dirigidas aos professores iniciantes. Assim tentou-se compreender a identidade docente que é forjada atualmente no âmbito da educação básica.

Daí o interesse de contrastar egressos de duas licenciaturas com perfil de atuação profissional (no caso da Pedagogia, Ensino Infantil e séries iniciais do Ensino Fundamental, e no caso da Biologia, séries finais do Ensino Fundamental e Ensino Médio) e estruturas curriculares diferentes (no que se refere à carga de disciplinas específicas, duração dos estágios obrigatórios, nível de articulação entre teoria e prática, etc.). A opção de olhar os professores iniciantes a partir do perfil do egresso da licenciatura constitui tentativa de colaborar com as instituições de formação prévia, os cursos de graduação em licenciatura, ao pontuar as continuidades e descontinuidades do desenvolvimento profissional.

Para além de uma nova compilação de saberes sobre a prática docente ou redefinição de critérios de profissionalidade, essa pesquisa procurou evidenciar a complexidade de referências, conhecimentos, habilidades e competências que são aprimorados ao longo da vida profissional.

Listas e categorizações de parâmetros ou referentes sobre função e a ação docente são úteis para orientar ou subsidiar processos de avaliação formativa e contribuir com processos de formação inicial e continuada, no que tangem a refletir sobre a prática. No entanto, estes recursos teórico-metodológicos não devem ser tomados a priori do debate sobre as ciências da Educação e sua importância de fundamentar a ação, sobretudo a Didática, sobre os cotidianos e contextos de trabalho que apresentam as situações e os desafios, e, principalmente, o necessário protagonismo da autonomia profissional que os professores constroem entre si.

Essa pesquisa, através do questionário elaborado e dos dados produzidos com os respondentes, representa um dos pontos de vista possíveis, diante da parcialidade em sua abordagem e objetivos predefinidos. O trabalho de Silva e Almeida (2015) seguem a mesma proposta de servir ao acompanhamento e reflexões sobre a docência e como uma "possível contribuição para uma dinâmica 
profissional em crescente qualificação social e valorização, pela densificação no que se refere aos aspectos da profissionalidade docente" (p. 11).

\section{2.}

\section{Dos egressos aos professores iniciantes}

A pesquisa com egressos enfrenta grande dificuldade em localizar seus informantes, mas oferece diversas e importantes informações sobre a escolha pelo curso, avaliação da formação inicial (relação entre a ocupação e a formação profissional recebida) e inserção profissional (atratividade da carreira, satisfação profissional, permanência e abandono). As dificuldades perpassam a quase inexistência de sistemas de acompanhamento de egressos por parte das instituições de ensino superior, dificuldades operacionais de contato e localização dos ex-alunos e o consentimento desses indivíduos em fornecer os dados de suas trajetórias profissionais.

Entretanto, a identificação das tensões, demandas e impressões oriundas de um curso de formação de professores na visão dos seus egressos e frente às exigências do mercado de trabalho possibilita adequação de propostas curriculares, monitoramento e implementação de políticas de formação de professores e ainda a compreensão da identidade profissional forjada pelos professores em início de carreira.

Ao pontuar as possibilidades e experiências com avaliações institucionais no Brasil, Meira e Kurcgant (2009) afirmam que a opinião do egresso quando no exercício de sua atividade profissional é uma das dimensões de análise dos cursos de graduação e das profissões. De acordo com as autoras:

O egresso enfrenta no seu cotidiano de trabalho situações complexas, que o levam a confrontar as competências desenvolvidas, durante o curso, com as requeridas no exercício profissional. Pode, a partir daí, avaliar a adequação da estrutura pedagógica do curso que foi vivenciado, bem como os aspectos intervenientes no processo de formação acadêmica. (MEIRA e KURCGANT, 2009, p. 482)

Indo além da proposição das autoras e dos trabalhos por elas citados, a evidenciação dos destinos ocupacionais e a busca por conhecer a atividade profissional e suas características nos contextos laborais na perspectiva dos egressos emergem como objetos de análise para a função docente. 
Brandalise (2012) ao comentar o papel das avaliações educacionais diante da centralidade das políticas públicas indica os propósitos controladores e fiscalizadores do Estado sobre os sistemas de ensino, na busca por melhores indicadores de desempenho, melhorias nos currículos e qualificação dos cursos e dos professores. Tal como Meira e Kurcgant (2009), Brandalise (2012) também inscreve a discussão de avaliação dos cursos de graduação no âmbito da lei 10.861/2004, que institui o Sistema Nacional de Avaliação da Educação Superior (SINAES), mais precisamente na dimensão das políticas de atendimento aos estudantes - item IX do artigo $3^{\text {a }}$ da referida lei (BRASIL, 2004).

A autora também chama atenção para a definição do termo egresso, indicando que há contextos que consideram nessa categoria todos os ex-alunos de um sistema escolar, incluindo-se os evadidos, transferidos e jubilados. Para esta pesquisa, consideramos egresso aquele ex-aluno que efetivamente concluiu os estudos, foi diplomado e se encontra apto ao exercício profissional que exige aquela formação.

A quase totalidade dos estudos consultados e analisados utilizou como estratégia metodológica localizar os professores iniciantes através dos locais ou redes de ensino onde atuam, particulares ou públicas. As investigações de Bueno Ambrosini (2012) e Pita (2011) serviram de inspiração para tentar compreender a construção da identidade docente e as representações sobre a formação e atuação profissional no início da carreira a partir do ponto de vista dos egressos de cursos de formação de professores em nível de licenciatura.

Privilegiou-se a proximidade temporal entre a saída da universidade e a entrada na escola, nos primeiros anos de exercício do magistério/docência, a fim de ponderar o destino desses professores recém-formados no mercado de trabalho e conhecer o que é mobilizado, valorizado e criticado acerca da prática docente.

\subsection{1. \\ Os produtores do corpus da pesquisa}

A partir dos contatos iniciais com as coordenações dos dois cursos, desde a época de elaboração do projeto e quando se obtiveram a aquiescência e a colaboração para acesso aos dados e sujeitos da pesquisa, foram marcadas outras reuniões a fim de apresentar o delineamento teórico-metodológico e definir a 
forma de envio dos questionários aos egressos a partir da plataforma virtual SurveyMonkey®. Esse site permite a montagem do questionário, o gerenciamento de convites aos informantes e o acompanhamento e armazenamento das respostas, bem como a exportação dos dados para o software de análises estatísticas IBM SPSS ${ }^{2} 20.0$ que, por sua vez, possibilitou o tratamento do banco de dados, a categorização de respostas e a obtenção das percentagens. A elaboração das tabelas finais e dos gráficos foi realizada no software Microsoft Excel®.

Ambas as coordenadoras apontaram a impossibilidade de fornecer diretamente os endereços eletrônicos dos ex-alunos e sugeriram o envio de uma mensagem pelo sistema de gestão acadêmica da universidade, convidando-os a participar da pesquisa. O sistema armazena dados cadastrais de alunos e exalunos, sendo usualmente utilizado para envio de informações relativo às disciplinas ao longo da realização do curso. No entanto, não se tinha certeza se os e-mails dos ex-alunos estavam atualizados no sistema.

De acordo com as atas de colação de grau e relatórios das secretarias acadêmicas, a população de egressos da Pedagogia entre os anos de 2009 e 2014 é de 356 ex-alunos e na Biologia é de 425. Essa informação só foi obtida na íntegra depois de encerrado o recebimento dos questionários respondidos, constituindo assim um dos motivos para a não realização de um estudo de inferências, tampouco censitário. Logo, não foram definidos critérios de amostragem, isto é, quantas pessoas deveriam ser inquiridas de modo que o estudo fosse representativo estatisticamente e assumiu-se que todos os questionários recebidos seriam utilizados nas análises. Os demais motivos para tais decisões foram a dificuldade de acesso aos contatos atuais e o tempo disponível para realizar a pesquisa.

O planejamento inicial era realizar a aplicação do questionário por dois meses, mas esse período foi alongado por um total de cinco meses em função de três fatos: um período de greve na universidade, o que impossibilitou o envio do questionário através do sistema de gestão acadêmica (procedimento que dependia de um funcionário da instituição), devido à baixa taxa de respondentes num primeiro momento e devido às dificuldades inerentes à localização desse tipo de informante, como apontado na literatura. Além do contato com as coordenações, outras estratégias para localizar e convidar os egressos para responder o questionário foram adotadas, tais como: buscou-se o auxílio dos professores 
responsáveis pela prática de ensino e pelo estágio supervisionado (componentes curriculares da licenciatura que são realizados ao final do curso), a divulgação da pesquisa em grupos de ex-alunos em redes sociais e a solicitação direta aos respondentes para que indicassem colegas de turma da graduação que se encaixavam no perfil da pesquisa, isto é, ter concluído o curso nos últimos seis anos.

O envio de mensagem pelo sistema de gestão acadêmica da universidade ofereceu um baixo número de respondentes válidos, possivelmente pelos dados cadastrais não terem sido atualizados pelos egressos e pela universidade não possuir um sistema de acompanhamento ou de avaliação da formação inicial junto aos ex-alunos da instituição. Ocorreu ainda o recebimento de respostas por egressos e por atuais alunos de outros cursos de graduação, o que sugere fragilidades no sistema informatizado da universidade. Esses dados tiveram que ser invalidados, juntamente com alguns casos de preenchimento incompleto do questionário.

A definição do período de análise, expresso pelo ano conclusão do curso, refere-se à categoria professor iniciante, que, segundo o referencial teórico adotado, compreende os seis primeiros anos de docência. Por motivo operacional na etapa de campo da pesquisa, realizada entre os meses de julho e dezembro de 2015, definiu-se a população amostral, isto é, aqueles que se encaixam no perfil de informante para o objeto de estudo em questão (professores com até seis anos de docência) dentre os egressos dos anos de 2009 a 2014.

No entanto, foram mantidas as respostas dos egressos que afirmaram ter concluído a graduação em 2008 (8 casos) e em 2015 (40 casos). A decisão levou em conta o referencial teórico para o ciclo de vida profissional dos professores, porém, com certa flexibilidade: o procedimento para colação de grau pode ocorrer em qualquer mês do ano, dependendo da demanda de formandos, e, sobretudo, a teoria deve ser tomada a serviço da compreensão da realidade e não a priori desta. Além disso, tempo de formado na licenciatura nem sempre é o mesmo tempo de efetivo exercício profissional, esse indicador foi adotado como critério de acesso aos sujeitos participantes da pesquisa, junto à IES onde se graduaram. Por isso a manutenção dos oito questionários de respondentes que se formaram em 2008.

A limpeza do banco de dados e a análise de consistência foram procedimentos importantes para remover respostas inválidas, como ex-alunos de 
outros cursos ou que ainda não tenham concluído a formação inicial, a fim de proceder à codificação de respostas abertas, seguido pelas análises estatísticas do material produzido. Esse estudo conta, portanto, com as respostas de 67 egressos do curso de Pedagogia (15,6\% dos concluintes) e 128 egressos do curso de Ciências Biológicas (25,4\% dos formados) no período entre os anos de 2009 e 2015 (Quadro 1). A apresentação desse dado serve apenas para se ter uma noção do alcance desta pesquisa perante o total de egressos que podem se encaixar na categoria professor iniciante. É preciso tomar tais valores percentuais como uma aproximação, já que foram incluídos na análise do corpus dessa pesquisa os oito casos de ex-alunos que terminaram o curso de Biologia no ano de 2008, para os quais a colação de grau ocorreu em dezembro de 2008 ou janeiro de 2009.

\section{Quadro 1 - Tamanho das populações amostrais e quantidade de participantes da} pesquisa

\begin{tabular}{|c|c|c|c|c|c|c|c|c|c|c|}
\hline Curso & Egressos & 2008 & 2009 & 2010 & 2011 & 2012 & 2013 & 2014 & 2015 & Total \\
\hline \multirow{2}{*}{ Pedagogia } & População & N.I. & 65 & 41 & 37 & 66 & 67 & 80 & 73 & 429 \\
\cline { 2 - 12 } & Respondentes & 0 & 1 & 0 & 6 & 10 & 14 & 15 & 21 & 67 \\
\hline \multirow{2}{*}{ Biologia } & População & N.I. & 82 & 82 & 74 & 73 & 58 & 56 & 47 & 472 \\
\cline { 2 - 11 } & Respondentes & 8 & 12 & 13 & 16 & 14 & 25 & 21 & 19 & 128 \\
\hline
\end{tabular}

Fonte: Elaborado pelo autor com base nos dados obtidos com as secretarias acadêmicas e coordenações dos dois cursos de graduação.

Nota: N.I. - não informado

A decisão em investigar as representações sobre a profissão a partir dos egressos desses dois cursos de licenciatura visou apresentar o percentual destes que se inseriram no mercado de trabalho e discutir a formação inicial frente as características, comprometimentos e aprendizagens percebidas nos diferentes contextos de trabalho como professores em início de carreira, como veremos a seguir. 


\section{4 Representações sobre a formação e o trabalho docente}

As duas populações inquiridas constituem-se de egressos de dois cursos de graduação de para formação de professores da educação básica. A caracterização do perfil foi feita com base nos dados produzidos junto aos respondentes desta pesquisa e não pode ser generalizada à estas populações, uma vez que não se pretendeu um estudo censitário ou amostral dos egressos da Pedagogia e da Biologia. Portanto, as afirmativas e percentagens devem ser consideradas uma sondagem de quem são os licenciados nesses dois cursos e o que pensam sobre a formação inicial e a entrada na profissão docente.

Primeiramente são abordadas questões relativas à trajetória escolar dos licenciados, às possíveis influências para a escolha do curso de licenciatura e uma avaliação da formação inicial sob a perspectiva daqueles que cumpriram a exigência mínima para atuar no mercado de trabalho como professor. Em seguida são apresentadas as representações sobre a profissão nos primeiros anos da docência e a discussão de comprometimentos e vivências dos egressos desses cursos que trabalham ou trabalharam como professores na educação básica.

\section{1.}

\section{Da universidade às escolas: Os egressos}

Dentre os respondentes, a maioria é do sexo feminino (82,1\% na Pedagogia e 64,8\% na Biologia), prevalecendo uma das características da chamada feminização do magistério que está ligada à constituição da identidade social da profissão docente no país. As outras características referem-se ao cuidado maternal associado ao entendimento de que a atividade de ensino é contígua à socialização primária feita em casa, ao fato da carga horária de trabalho ser ajustável ao trabalho doméstico culturalmente definido como tarefa feminina e por ser uma ocupação de caráter provisório. André (2002), evidencia a relevância do tema ao apresentar um estado do conhecimento sobre as pesquisas de formação de professores e como a feminização da profissão foi analisada e discutida, 
frequentemente associada à discriminação contra a mulher e à grande influência sobre a identidade e a profissionalização docente.

Tais características estão associadas ao crescimento da profissão e à distribuição desigual dos postos de trabalho em função do gênero, bem como à imagem subalternizada da mulher em nossa sociedade. Os movimentos de ampliação do atendimento escolar somados às iniciativas de profissionalização docente (via exigência de uma formação específica) ao longo do século XX atraíram e atraem um grande contingente de mulheres para a carreira. No entanto, essa oferta não é preenchida por homens que tradicionalmente são direcionados para outras carreiras. A identidade sócio historicamente construída para o trabalho docente está associada a uma atividade feminina, por isso, com baixo prestígio acadêmico/social e baixas remunerações se comparado a outras carreiras ocupadas majoritariamente por homens.

A idade dos respondentes variou entre 22 e 60 anos, tendo média de 31 anos para Pedagogia e 27 anos para Biologia, a moda foi de 25 e 26, respectivamente. De forma análoga ao estudo de Maciente et al (2015), com base na vinculação entre os dados do ENADE 2011 e os microdados da RAIS/MTE 2012, constatouse que dentre os recém-formados em cursos de licenciatura (14 carreiras universitárias foram analisadas pelos autores) a quantidade de mulheres é de 92,8\% na Pedagogia e 70,0\% na Biologia e que possuem idade média de 27,1 e 33,4 anos.

A distribuição em faixas etárias e por sexo (Quadro 2) foi elaborada a partir do agrupamento e cruzamento dos dados fornecidos, nela verifica-se que a faixa etária mais densa é a de 25 a 29 anos para ambos os grupos (37,3\% na Pedagogia e $69,3 \%$ na Biologia). Ao se considerar que a questão foi respondida por concluintes de um período de seis anos, podemos afirmar que há uma predominância de mulheres jovens (com idades entre 25 e 29 anos) e que a distribuição entre as faixas é mais homogênea para as egressas do curso de Pedagogia. Não se buscaram correlações entre idade cronológica e fases do ciclo profissional, conforme alerta Huberman (1992). Moura (1998, p. 68) sintetiza as observações de invalidade que o autor apresenta a partir de críticas às abordagens psicológicas e maturacionais: "questiona[r] o modelo ontogênico que propõe a existência de sequências pretensamente universais, predeterminadas e invariáveis, independentemente das diferenças de condições sociais ou de período histórico. 
Quadro 2 - Distribuição dos egressos por faixas etárias e sexo

\begin{tabular}{|c|c|c|c|c|c|c|c|}
\hline \multirow{2}{*}{ Faixas etárias } & \multicolumn{3}{|c|}{ Pedagogia } & \multicolumn{3}{c|}{ Biologia } & \multirow{2}{*}{ Total } \\
\cline { 2 - 7 } & Feminino & Masculino & Total & Feminino & Masculino & Total & \\
\hline 20 a 24 anos & $16,4 \%$ & $3,0 \%$ & $19,4 \%$ & $10,2 \%$ & $4,7 \%$ & $15,0 \%$ & $16,5 \%$ \\
\hline 25 a 29 anos & $26,9 \%$ & $10,4 \%$ & $37,3 \%$ & $47,2 \%$ & $22,0 \%$ & $69,3 \%$ & $58,2 \%$ \\
\hline 30 a 39 anos & $20,9 \%$ & $3,0 \%$ & $23,9 \%$ & $6,3 \%$ & $5,5 \%$ & $11,8 \%$ & $16,0 \%$ \\
\hline Acima de 40 anos & $17,9 \%$ & $1,5 \%$ & $19,4 \%$ & $1,6 \%$ & $2,4 \%$ & $3,9 \%$ & $9,3 \%$ \\
\hline Total & $82,1 \%$ & $17,9 \%$ & $100,0 \%$ & $64,8 \%$ & $35,2 \%$ & $100,0 \%$ & $100,0 \%$ \\
\hline
\end{tabular}

Fonte: Elaborado pelo autor.

Atribui-se essa distribuição à procura de mulheres de variadas idades pelo curso de Pedagogia, enquanto o curso de Biologia tende a ser mais procurado por jovens na faixa etária esperada para início da formação em nível superior, isto é, logo após a conclusão do ensino médio. A UNESCO (2004) chama a atenção para os professores brasileiros serem relativamente mais jovens, em média, do que em países pertencentes à Organização de Cooperação e Desenvolvimento Econômico (OCDE). A organização sinaliza preocupação com a renovação dos quadros docentes por efeito de aposentadorias e abandonos da profissão e ainda a relação entre experiência e aceitação de novas concepções pedagógicas.

A trajetória de escolarização dos pais (Quadro 3) é um dos critérios para se entender o acesso e a amplitude de escolarização dos filhos, bem como o nível de seu capital cultural e informacional. A literatura aponta que há uma tendência entre aqueles que realizam os cursos de licenciatura possuírem os mais baixos rendimentos escolares no ensino médio, serem oriundos de núcleos familiares de baixa renda e com trajetórias escolares curtas ou precárias (UNESCO, 2004).

Quadro 3 - Nível de escolaridade das mães e dos pais

\begin{tabular}{|c|c|c|c|c|}
\hline \multirow{2}{*}{ Escolaridade } & \multicolumn{2}{|c|}{ Pedagogia } & \multicolumn{2}{c|}{ Biologia } \\
\cline { 2 - 5 } & Mãe & Pai & Mãe & Pai \\
\hline Não sei & - & - & - & $1,6 \%$ \\
\hline Nenhum & - & $1,5 \%$ & $0,8 \%$ & $2,3 \%$ \\
\hline Ensino Fundamental incompleto & $26,9 \%$ & $29,9 \%$ & $11,7 \%$ & $10,2 \%$ \\
\hline Ensino Fundamental completo & $9,0 \%$ & $14,9 \%$ & $3,1 \%$ & $4,7 \%$ \\
\hline Ensino Médio incompleto & $4,5 \%$ & $14,9 \%$ & $3,9 \%$ & $5,5 \%$ \\
\hline Ensino Médio completo & 28,4 & $22,4 \%$ & $22,7 \%$ & $24,2 \%$ \\
\hline Ensino Superior incompleto & $4,5 \%$ & $3,0 \%$ & $12,5 \%$ & $3,1 \%$ \\
\hline Ensino Superior completo & $19,4 \%$ & $16,4 \%$ & $29,7 \%$ & $32,8 \%$ \\
\hline Pós-Graduação & $7,5 \%$ & $9,0 \%$ & $15,6 \%$ & $15,6 \%$ \\
\hline
\end{tabular}

Fonte: Elaborado pelo autor. 
Dentre os egressos da Pedagogia, os valores são similares para pais e mães que apresentam em sua maioria a escolaridade básica $(28,4 \%$ das mães com ensino médio completo e $29,9 \%$ dos pais com ensino fundamental incompleto) e menos de 20\% com nível superior. Já entre os ex-alunos da Biologia, observa-se uma trajetória de escolarização maior para seus pais e mães. Os percentuais indicam que os pais possuem ligeira vantagem sobre as mães, ambos com nível superior completo $(29,7 \%$ das mães e $32,8 \%$ dos pais) e ambos com pósgraduação (mais de 15\%).

Isso evidencia um significativo avanço em relação à pesquisa publicada pela UNESCO em 2004, quando observou-se que cerca de metade dos pais e mães dos professores brasileiros não possuíam sequer o ensino fundamental completo. A presente pesquisa vai ao encontro da afirmativa da própria organização em outro levantamento sobre os professores do Brasil: "Pais e mães dos estudantes de Pedagogia são sistematicamente menos escolarizados que os dos estudantes dos demais cursos." (UNESCO, 2009, p. 167).

Sobre a sua própria trajetória escolar no ensino médio (Gráfico 1), 52,2\% dos respondentes da Pedagogia fizeram o curso regular e 23,9\% o curso Normal/Magistério. Entre os egressos da Biologia, 73,4\% concluíram o regular e $22,7 \%$ realizaram um curso de nível médio técnico/profissionalizante. A modalidade apresentou grande variação, sem correlação com o estudo da UNESCO (2009), que serviu de base para elaboração da questão, usando a nomenclatura adotada pelo ENADE (fonte dos dados da referida pesquisa).

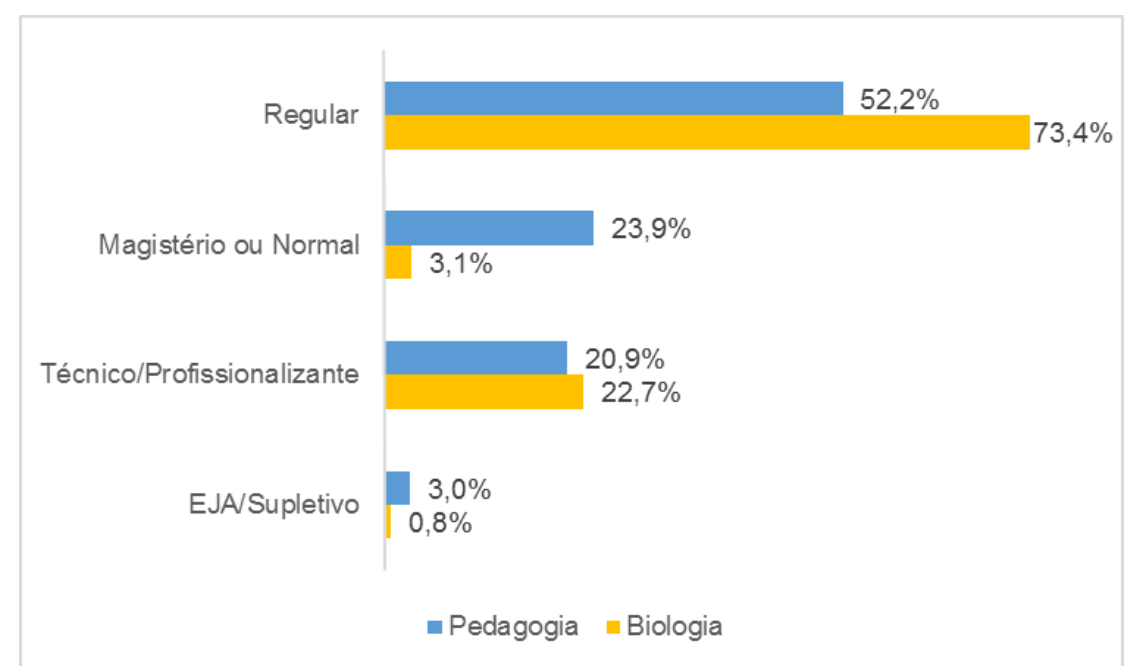

\section{Gráfico 1 - Tipo de Ensino Médio frequentado}

Fonte: Elaborado pelo autor. 
Sobre a escolha do curso de graduação, a grande maioria (86,6\% na Pedagogia e $89,1 \%$ na Biologia) disse ter sido sua primeira opção para acesso ao nível superior, tal como observado por Wzorek (2009), quando apenas 6,1\% afirmaram que o magistério não tinha sido sua primeira opção no vestibular.

Quando solicitados a avaliar a importância de afirmativas que sumarizam os motivos para escolha do curso de licenciatura (Gráfico 2), os respondentes de ambos os cursos destacaram como muito importante 'Contribuir para o meu desenvolvimento intelectual' (69,8\% na Pedagogia e 52,4\% na Biologia), como importante 'Alcançar a estabilidade profissional' (47,6\% e 45,2\%) e como nada importante 'Menor relação candidato/vaga' (54,0\% e 66,7\%), 'Ter o magistério como outra opção profissional, porém não a primeira' $(60,3 \%$ e $38,1 \%)$ e 'Influência da família/amigos para essa área de atuação' (52,4\% e 44,4\%).

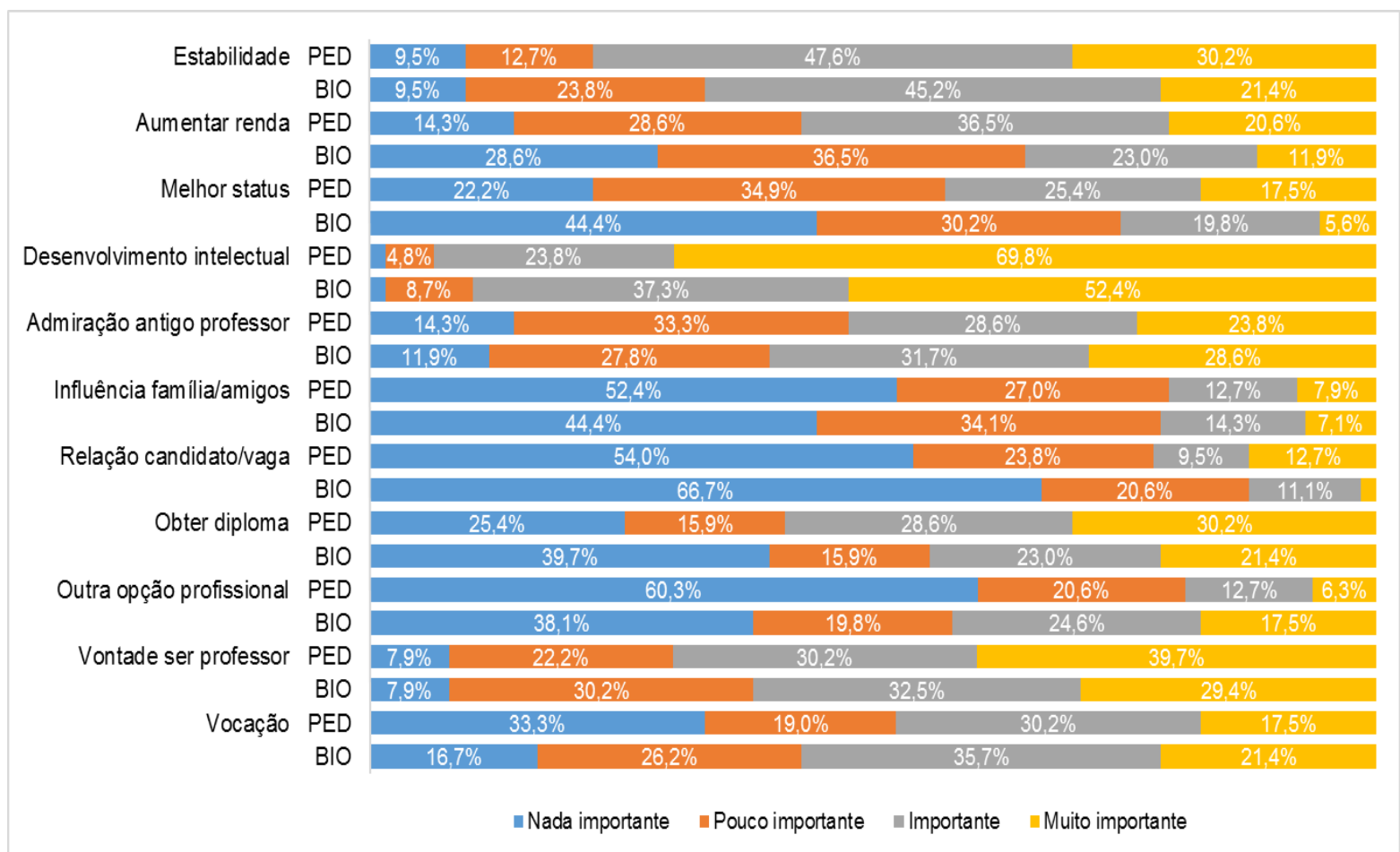

\section{Gráfico 2 - Motivações para escolha do curso de licenciatura}

Fonte: Elaborado pelo autor.

Dados similares foram apontados pela UNESCO (2009): dentre as razões para escolha do curso 'ter uma outra opção se não conseguir exercer outro tipo de atividade' foi apontado apenas por 13,3\% dos estudantes de Pedagogia e por $23,9 \%$ dos estudantes de outras licenciaturas, 'influência da família' por 5,2\% e $3,5 \%$, 'um bom professor que me serviu de modelo' por 6,6\% e 13,6\%. O grande 
destaque foi para 'quero ser professor' com $65,1 \%$ e 48,6\% das opiniões. Wzorek (2009), em pesquisa com professores de disciplinas específicas, observou o 'desejo de ser professor' como motivo decisivo para 43,4\%, a 'estabilidade no emprego' pesou muito na escolha para $37,3 \%$ e a 'melhoria de renda ou de status social' teve alguma influência para apenas $27,4 \%$.

De maneira geral, os egressos da Pedagogia não indicam a 'vocação' ou 'obter diploma de curso superior' como algo relevante para escolha desse curso. Aumento de renda e melhoria status em relação à família também figuram como itens com homogênea distribuição de importância. Enquanto os da Biologia veem vocação como algo importante, os demais motivos têm pouca ou nenhuma importância. Da mesma forma que Gatti (2010), destacamos como uma espécie de "seguro desemprego" o fato do magistério ser percebido como uma alternativa secundária de atividade profissional e fonte de renda para $19 \%$ dos licenciados em Pedagogia e $42,1 \%$ em Biologia que atribuíram como importante ou muito importante na escolha do curso de licenciatura.

Os $\operatorname{comentários}^{22}$ à questão ilustram o comprometimento pessoal e a vocação como elementos que levaram à escolha do curso de licenciatura e à profissionalização (nesse caso, obtenção do título e chancela para o exercício profissional) para a futura atuação como professor: "Realização pessoal" [P10] e "O curso de Pedagogia foi o caminho mais prático para adquirir uma formação profissional" [P168]. Alguns comentários, por sua vez, indicam uma escolha tardia pelo magistério daqueles que procuravam o bacharelado de Ciências Biológicas ${ }^{23}$, ao invés da licenciatura: "o único curso noturno era de licenciatura. Não era oferecido bacharelado à noite" [B19] e "facilidade para emendar o bacharelado com a licenciatura" [B194]. A princípio observa-se a preferência pelo curso de bacharelado e, inclusive, a estratégia de ingresso pela licenciatura com a expectativa de pleitear a manutenção de vínculo para finalmente realizar o bacharelado. Essa descoberta da educação durante o curso de licenciatura, seja na Pedagogia, seja na Biologia, será retomada adiante.

\footnotetext{
${ }^{22}$ A identificação das falas dos respondentes foi feita usando um código formado pela letra B, de Biologia, ou $\mathrm{P}$, de Pedagogia, seguido pelo número do questionário no banco de dados, em função da ordem de recebimento do mesmo preenchido.

${ }^{23}$ Essa modalidade só é oferecida no turno do dia e não no noturno. As três falas que mencionam o bacharelado sugerem uma possível demanda por um curso noturno com o bacharelado em Biologia.
} 
A atuação como professor antes de iniciar a graduação foi apontada por $34,3 \%$ dos respondentes da Pedagogia (como emprego para 58,8\% destes e em aulas particulares para 23,5\%) e para $19,7 \%$ da Biologia (sendo 29,2\% destes como auxiliares ou monitores, $20,8 \%$ através de aulas particulares e 20,8\% como voluntários). A experiência prévia à formação inicial mínima exigida em lei pode ser considerada como manifestação da vocação para a atividade pedagógica, um encantamento desassociado ao exercício da docência como fonte de renda. Além de prática regulamentada dentre aqueles que fizeram o Curso Normal/Magistério no Ensino Médio.

Lelis (1996) relativiza a vocação como algo resultante de condicionamentos sociais e culturais, oriundos desde a socialização primária e ao longo da trajetória de vida dos indivíduos. A autora pondera a reprodução de uma disposição, socialmente difundida, que reitera comportamentos e tendências "femininos" e "masculinos", que "naturaliza" escolhas desde a infância. A partir dos resultados de entrevistas, Lelis evidenciou lembranças e trajetórias marcadas por esses condicionamentos e propõe que muitas das professoras entrevistadas foram "marcada[s] por certos códigos de conduta no plano da moral, dos costumes que precisam ser analisados para uma maior complexificação da ideia de "vocação" (LELIS, 1996, p. 67-68). Vocação é, portanto, uma construção social inscrita num esquema de percepção e ligado à uma experiência durável de uma posição no mundo social que influenciam, por sua vez, possibilidades de conservação (tradição) ou ruptura, e são influenciadas, pela circulação em diferentes campos, isto é, um habitus. A autora discute ainda concepções do papel e do lugar da mulher na sociedade e indica que “a 'vocação' para o magistério nasceu e se desenvolveu no interior de determinadas instituições, espaços de interação social onde estas professoras circularam" (LELIS, 1996, p. 72).

Ainda sobre uma vocação para o magistério, Valle (2006, p.179) alerta que

Ao contrário do que revela o senso comum, o destino de uma pessoa não se prende somente às características próprias de sua personalidade (...), mas depende principalmente do fato de ter nascido num determinado momento histórico e num certo ambiente sociocultural, definido por elementos estruturais bem precisos: de ordem econômica, política, educacional. Esses elementos pesam sobre as opções de cada um e acabam por prescrever o futuro no mais longo termo, orientando a escolha pessoal e exercendo forte influência sobre o itinerário profissional. O apelo à vocação para justificar as escolhas profissionais, como salientou Bourdieu (1998), visa produzir encontros harmoniosos entre as disposições e as posições, 
fazendo com que as vítimas da dominação simbólica possam desempenhar com satisfação as tarefas subalternas ou subordinadas, atribuídas às suas virtudes de submissão, gentileza, docilidade, devotamento e abnegação.

Corrobora-se com as duas autoras sobre uma suposta vocação para o magistério, especialmente quando tratada do ponto de vista da feminização da atividade docente, relacionada à subalternização e que contribui para um menor estatuto profissional, como visto anteriormente com André (2002) e Guimarães (2006). A vocação ter sido apontada como um item de média importância pelos respondentes dessa pesquisa sinaliza pelo menos duas hipóteses: o desejo e a nãoescolha de ser professor ${ }^{24}$.

A categorização das respostas abertas em 'emprego', 'aulas particulares', 'auxiliar/monitor' e 'voluntário' emergiu da fala dos respondentes que se utilizaram de expressões como "fui professora", "trabalhei com educação infantil" e ainda a discriminação nominal do cargo que ocupou ou da atividade exercida. Destaca-se, ainda, que 80,3\% dos egressos da Pedagogia e 52,1\% da Biologia concordam com a afirmativa 'Ao entrar no curso de graduação já possuía a vontade de trabalhar como professor'. A seguir, na discussão do Gráfico 5, serão analisados como esse e outros tópicos relativos à formação inicial são percebidos pelos licenciados. Frisar a construção da identidade profissional a partir das vivências como aluno e como professor, bem como nos espaços formativos formais e informais, são elementos da profissionalidade docente.

Ao longo da graduação a experiência com projetos de pesquisa foi a atividade mais comum tanto na Pedagogia (67,2\%) quanto na Biologia $(77,3 \%)$, numa lista que incluía: projetos de extensão, pesquisa, estímulo à docência, monitoria na graduação e na educação básica, além de nenhuma das anteriores (Gráfico 3). Novamente buscou-se elementos da constituição da profissão, isto é, características e disposições para o exercício da docência, desenvolvidos ou experimentados durante a formação inicial. Como dito anteriormente, entende-se por formação inicial, a formação em nível superior, exigência legal para o exercício profissional de professor da educação básica, conforme a LDB 1996 e o PNE 2014-2024.

\footnotetext{
${ }^{24}$ Esta é uma importante discussão sobre universitarização e profissionalização, porém exige um aprofundamento tanto empírico quanto teórico, que vão além da proposta dessa pesquisa.
} 


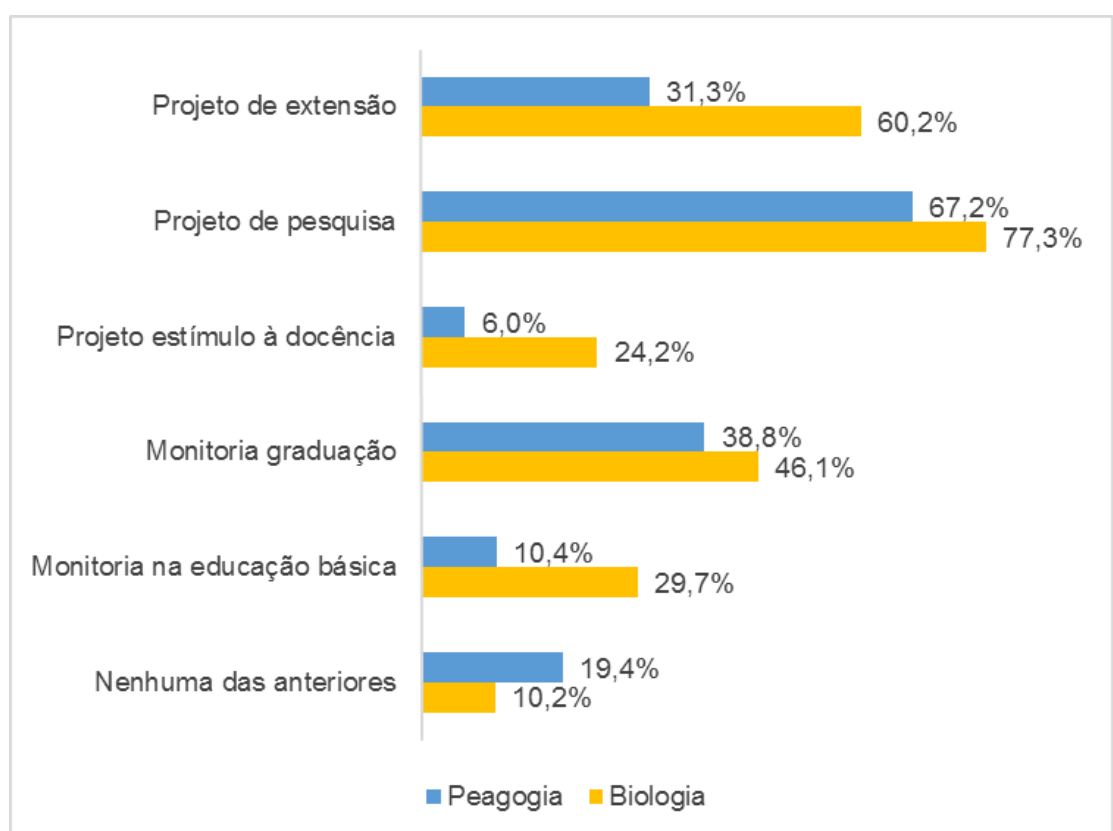

\section{Gráfico 3 - Experiências formativas ao longo da graduação}

Fonte: Elaborado pelo autor.

Nota: Pergunta com resposta múltipla e frequências com base no total de respondentes.

$\mathrm{Na}$ questão solicitava-se apenas que o egresso marcasse as opções com as quais 'teve experiência', aqui chama-se a atenção para a ampla possibilidade de entendimentos, uma vez que o caráter da experiência (contínua ou pontual, participação efetiva no desenvolvimento ou mero conhecimento de sua existência) não foi explicitado. Ainda assim, o grande envolvimento dos ex-alunos com atividades de pesquisa é característica desses cursos, uma vez que estão associados a programas de pós-graduação antigos e com um corpo docente com alta produção acadêmica tanto nas áreas de ciências biológicas como na grande área de educação. Em segundo lugar aparece 'monitoria de disciplinas da graduação' para 38,8\% na Pedagogia e 'projetos de extensão' para 60,2\% na Biologia. A participação nessas três atividades está relacionada também com os programas de concessão de bolsas da universidade, os quais abrangem todas as atividades listadas, o que vai na direção da almejada tríade de atuação, ou tripé de sustentação como descrito nos documentos da universidade, para o seu funcionamento.

Acerca da formação inicial, em caráter avaliativo-reflexivo, foi solicitado que os licenciados desses dois cursos ponderassem a relevância de grupos de disciplinas e itens curriculares da graduação frente a atuação do professor nos contextos de trabalho na educação básica (Gráfico 4). Todas as opções foram 
apontadas como relevantes ou muito relevantes, em sua maioria, para ambos os grupos de egressos.

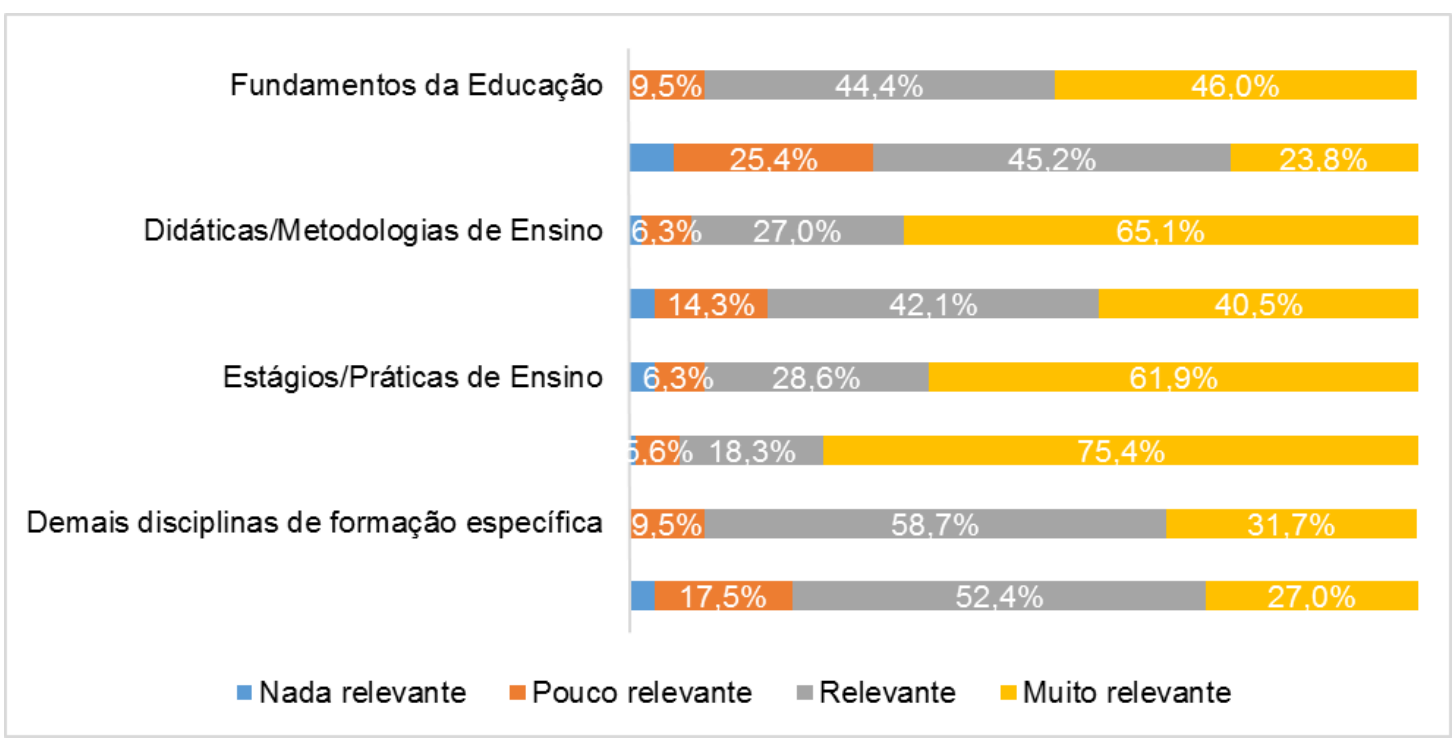

\section{Gráfico 4 - Relevância das disciplinas do curso de licenciatura}

Fonte: Elaborado pelo autor.

Os itens considerados muito relevantes e com os maiores valores percentuais foram 'Didáticas/Metodologias de Ensino' com 65,1\% para os respondentes da Pedagogia e 'Estágios/Práticas de Ensino' com 75,4\% para os respondentes da Biologia. As disciplinas agrupadas como 'Fundamentos da Educação (História, Psicologia, Filosofia e Sociologia da Educação)' tiveram 9,5\% respostas da Pedagogia como pouco relevantes e na Biologia, 25,4\%. Tais opiniões não interferem na ampla maioria que reconhece a importância que esses elementos curriculares possuem na formação, mas evidencia que disciplinas com discussões e abordagens práticas, do tipo "como fazer" ou "como ensinar" são mais valorizadas pelos professores recém-formados. Os professores indicam a defasagem da formação sobre a finalidade da profissão: ensino implica em aprendizagem (núcleo da especificidade da ocupação, que exige articulação com o conhecimento científico sistematizado).

Tanto as disciplinas de fundamentos como as de formação específica tiveram a relevância minimizada possivelmente em função do excesso de teorizações seja dos conteúdos pedagógicos, seja dos conteúdos disciplinares próprios da formação em Pedagogia e em Biologia. Gatti (2010, p. 1369) ao analisar os currículos de alguns cursos de licenciatura, afirma que no caso da 
Pedagogia nas disciplinas mais relacionadas à formação profissional específica predominam enfoques teóricos "contemplando muito pouco as práticas educacionais associadas a esses aspectos. As disciplinas deste grupo trazem ementas que registram preocupação com as justificativas sobre o porquê ensinar". Sobre as licenciaturas em Ciências Biológicas, Gatti e Barreto em relatório da UNESCO (2009) afirmam que 64,3\% das disciplinas obrigatórias referem-se aos conhecimentos específicos da área e apenas 10,4\% acerca de conhecimentos específicos para a docência. De acordo com o relatório, "A separação que se percebe entre conteúdos das áreas específicas de Biologia e de formação pedagógica apresenta elementos históricos desde o surgimento dos cursos de Ciências Biológicas" (p.150).

O distanciamento entre teoria e prática é observado tanto na Pedagogia quanto nas licenciaturas de cunho disciplinar. O modelo de formação $3+1$, três anos de formação específica e um ano de formação pedagógica com imersão no universo escolar ao longo do estágio curricular em docência, não contribui para reaproximar teoria e prática e fazer a ponte reflexiva que permita melhoria da qualidade do processo de ensino-aprendizagem. Candau e Lelis (2005) já alertavam no início dos anos $1980^{25}$ sobre como teoria e práticas educacionais devem constituir núcleo articulador da formação, de maneira a considerar na sua análise os determinantes socioestruturais, e que a competência profissional não deve ser reduzida à dimensão técnica. Tal preocupação e crítica aparece na estratégia 15.8 do PNE “valorizar as práticas de ensino e os estágios nos cursos de formação de nível médio e superior dos profissionais da educação, visando ao trabalho sistemático de articulação entre a formação acadêmica e as demandas da educação básica" (BRASIL, 2015) e com frequência nos comentários dos egressos, tanto da Pedagogia quanto da Biologia, sobre a relevância das disciplinas de graduação:

"As didáticas deveriam ser mais valorizadas" [P97], "Poderiam no âmbito geral
serem mais próximas do exercício da atividade docente e menos teóricas" [B150],
"As práticas de Ensino deveriam iniciar no primeiro período e a carga horária
deveria ser a maior de todas. Acredito que acompanhar a mesma turma durante um
ciclo/ano completo e compreender melhor o funcionamento da escola seria vital
para a formação dos futuros profissionais da educação." [P168], "Acredito que

${ }^{25}$ Chama-se a atenção para a publicação original do livro em 1988 e desse texto em 1983. 
todas foram relevantes para a minha profissão, porém, deveriam ser dadas de forma melhor. As de Educação por exemplo, poderiam ser dadas com estratégias de atividades para a aula ficar mais dinâmica, ao invés de ser só discussão dos textos. No meu Mestrado em Educação, está muito mais interessante estudar sobre os autores. Acho que a prática de ensino poderia ser mais do que só assistir e analisar as aulas dos professores. $\mathrm{E}$ as demais disciplinas, acredito que algumas poderiam ser focando na licenciatura" [B83]

A fim de proceder com uma avaliação da formação inicial, foi solicitado aos egressos o grau de concordância ou discordância para uma sequência de frases sobre a realização do curso de licenciatura (Gráfico 5). A vontade de trabalhar como professor apresentou concordância de $80,3 \%$ ao entrar no curso e subiu para $85,2 \%$ ao final dentre os egressos da Pedagogia.

Há uma predominância de uma escolha como projeto de vida ou escolha precoce, não raro associada ao sentimento de vocação, onde a realização da licenciatura veio suprir o desejo imanente de ser professor ${ }^{26}$. A vocação está ligada a um resquício da visão tradicional sobre a ocupação docente, a qual está sendo relativizada pelas mudanças no papel da mulher na sociedade e no papel do professor nos sistemas educacionais.

A escolha tardia pelo magistério, que se manifesta durante a realização da graduação e o contato com as discussões educacionais, também foi observada, embora mais explícita dentre os respondentes da Biologia. A mudança de percepção destes sobre a vontade de trabalhar como professor ao começar a licenciatura aumentou de $18,2 \%$ (concordam totalmente) para $52,1 \%$ ao final do curso. Em ambos os grupos de egressos observa-se a queda na discordância total sobre esse item, tomando o início e o final do curso como referência: 9,8\% para $1,6 \%$ na Pedagogia e $28,9 \%$ para $6,6 \%$ na Biologia.

"passei a gostar de dar aula ao longo do curso" [B83], "Escolhi o curso porque trabalhava em recursos humanos, mas quando conheci a educação me realizei" [P91], "Quando prestei vestibular no ano que passei, eu trabalhava de dia e só havia biologia no período noturno, porém, era licenciatura. pensava em ser bióloga marinha, mas depois me identifiquei com a licenciatura." [B166]

\footnotetext{
${ }^{26}$ A argumentação é perigosa, uma vez que, mesmo gostos e desejos são oriundos de socialização e incorporação de disposições. Reconhece-se o peso social atribuído à não-escolha profissionalizante em função do gênero e origem socioeconômica, mas também se enfatizam as transformações nas últimas décadas acerca do empoderamento da mulher, bem como as mutações
} 


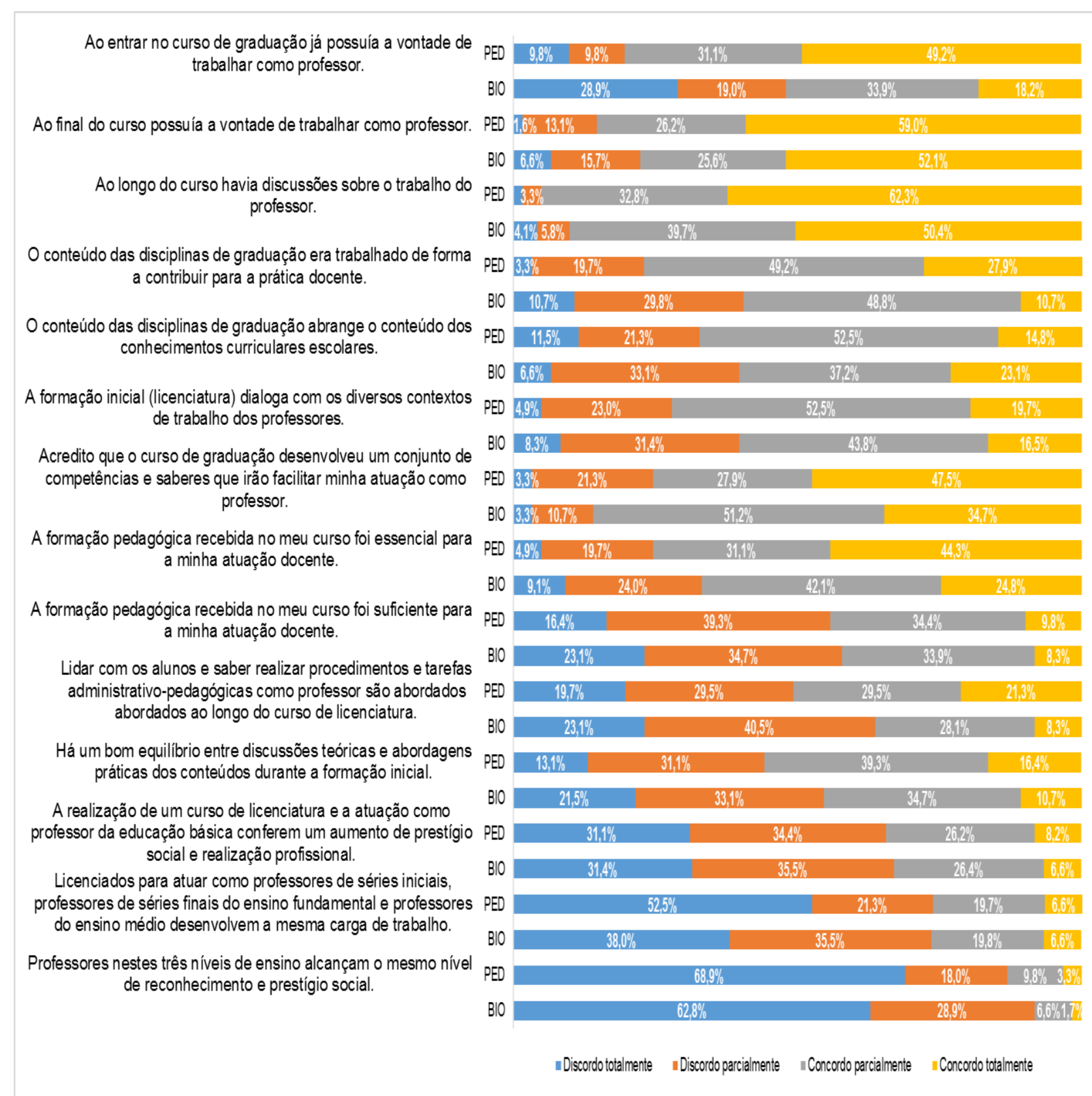

\section{Gráfico 5 - Avaliação da formação inicial frente a atuação como professor}

Fonte: Elaborado pelo autor.

As demais frases referem-se a elementos do curso face o trabalho docente. A ocorrência de discussões sobre o trabalho do professor foi corroborada por mais de 90\% (somando-se a concordância total e parcial) de ambos os grupos de egressos, porém 27,9\% na Pedagogia e 39,7\% na Biologia discordam que tais discussões dialogam sobre os contextos de trabalho docente. Sobre o conteúdo das disciplinas de graduação, cerca de metade dos egressos concorda parcialmente que

na profissão docente, frequentemente vinculadas à precarização versus a busca por maior 
elas contribuem para prática docente e que abrangem o conteúdo dos conhecimentos curriculares escolares.

Mais de $75 \%$ dos egressos de ambos os cursos concordam que a licenciatura desenvolveu competências e saberes que facilitem a atuação como professores, no entanto a formação pedagógica recebida no curso é tida como essencial para $75,4 \%$ na Pedagogia e 66,9\% na Biologia. Quando questionados se ela foi suficiente, a dispersão de opiniões foi grande, mas a maioria (mais de 55\% em ambos os cursos) discorda. Esses dados vão ao encontro dos depoimentos que apontam que a formação inicial poderia ser mais centrada em conteúdos e competências do trabalho do professor na escola e no envolvimento com a prática pedagógica em sala de aula, aumentando-se o tempo e a diversidade dos espaços onde se discuta e se exercita a prática docente, tal como nos estágios e disciplinas de metodologias de ensino e didática.

Gatti (2012b, n.p.) em balanço sobre o início da carreira docente no Brasil, indica que a "falta de política clara, nos diversos níveis de gestão da educação básica, sobre o que se espera, como condição inicial, dos professores, nas respectivas redes" está associada à recorrência, nas investigações conduzidas no período de 1965 a 2011, da inadequação, ou insuficiência, da formação inicial para atender:

à realidade das escolas e dos alunos, dificuldades didático-pedagógicas e de informação em relação aos componentes curriculares, problemas para a seleção de atividades relacionadas aos objetivos de ensino, ao desenvolvimento da avaliação dos alunos; ao comportamento dos alunos.

Sobre a abordagem de procedimentos e tarefas administrativo-pedagógicas e um equilíbrio entre discussões teóricas e abordagens práticas dos conteúdos, não houve consenso se estão presentes ou não ao longo da formação inicial, à exceção dos egressos da Biologia que sinalizam não ter tanta familiaridade com o trabalho do professor na educação básica. Levanta-se como hipótese o trabalho dos professores da educação infantil e séries iniciais do fundamental estar mais centrado no desenvolvimento dos alunos enquanto o trabalho dos professores das séries finais do fundamental e do ensino médio estar mais centrado nos conteúdos 
curriculares. A hipótese se baseia na maior interação pessoal e afetiva dos professores egressos da Pedagogia com seus alunos e na maior preocupação em cumprir os prazos e percorrer os conteúdos entre os professores de disciplinas específicas.

Marcelo (2009) afirma que é grande a insatisfação dos professores sobre a formação inicial recebida e com a capacidade de respostas das instituições formadoras frente as necessidades da profissão. $\mathrm{O}$ autor enumera as principais críticas relatadas sobre o tema: "a organização burocratizada, em que se assiste um divórcio entre a teoria e prática, uma excessiva fragmentação do conhecimento ensinado, um vínculo tênue com as escolas" (MARCELO, 2009, p. 13).

Acerca da valorização da autonomia construída, concorda-se com Pimenta (2006, p. 73) quando afirma que professores e escolas não devem ser considerados meros executores de decisões técnicas e burocráticas gestadas de fora, mas sim "como capazes de pensar e de articular os saberes científicos, pedagógicos e da experiência na construção e na proposição das transformações necessárias às práticas escolares e às formas de organização dos espaços de ensinar e aprender."

As afirmativas sobre a relação entre o curso de licenciatura e o prestígio social tiveram forte discordância, superior a $65 \%$. Como veremos a seguir, os egressos e os professores iniciantes participantes dessa pesquisa, reconhecem a importância da profissão e assumem os comprometimentos éticos e reflexivos da atividade docente, mas não percebem o reconhecimento pela sociedade.

Dentro da própria profissão há uma hierarquia de prestígio e os egressos manifestam essa diferenciação de status pela discordância total de 52,5\% na Pedagogia e $38,0 \%$ na Biologia quando ponderam se licenciados para atuar como professores de séries iniciais, professores de séries finais do ensino fundamental e professores do ensino médio desenvolvem a mesma carga de trabalho e 68,9\% na Pedagogia e $62,8 \%$ na Biologia sobre professores nestes três níveis de ensino alcançam o mesmo nível de reconhecimento.

Entre os egressos da Pedagogia 42,4\% afirmam ter iniciado de imediato em um emprego como professor, após a conclusão da graduação. Para os da Biologia esse percentual é de 31,4\%. Muitos desses profissionais consideraram sua atuação como professores mesmo antes da formação inicial (licenciatura), seja por terem realizado um curso de formação de professores em nível de ensino médio, seja por 
terem dado aulas particulares ou monitorias. O dado é impreciso também em função da continuidade no emprego via efetivação (no caso de emprego na rede particular de ensino) ou progressão de carreira (na rede pública) de um vínculo anterior à conclusão da licenciatura.

Solicitados a indicar a situação/ocupação após a conclusão da graduação (Gráfico 6), a categoria 'desempregado' foi apontada por 15,3\% dos formados em Pedagogia e por 12,4\% dos formados em Biologia. Desemprego é uma condição de difícil precisão, uma vez que o entendimento dela pode estar associado ao trabalho formal ou ao informal, em face de emprego autônomo, assalariado ou profissional liberal, etc. Portanto, nesta pesquisa, considera-se 'desempregado' como situação indefinida, incluindo a não ocupação de qualquer posto de trabalho e 'taxa de ocupação' o somatório de percentagens dentre as seguintes opções de respostas: 'trabalhando como professor', 'trabalhando na área de educação, mas não como professor' e 'trabalhando fora da área de educação'.

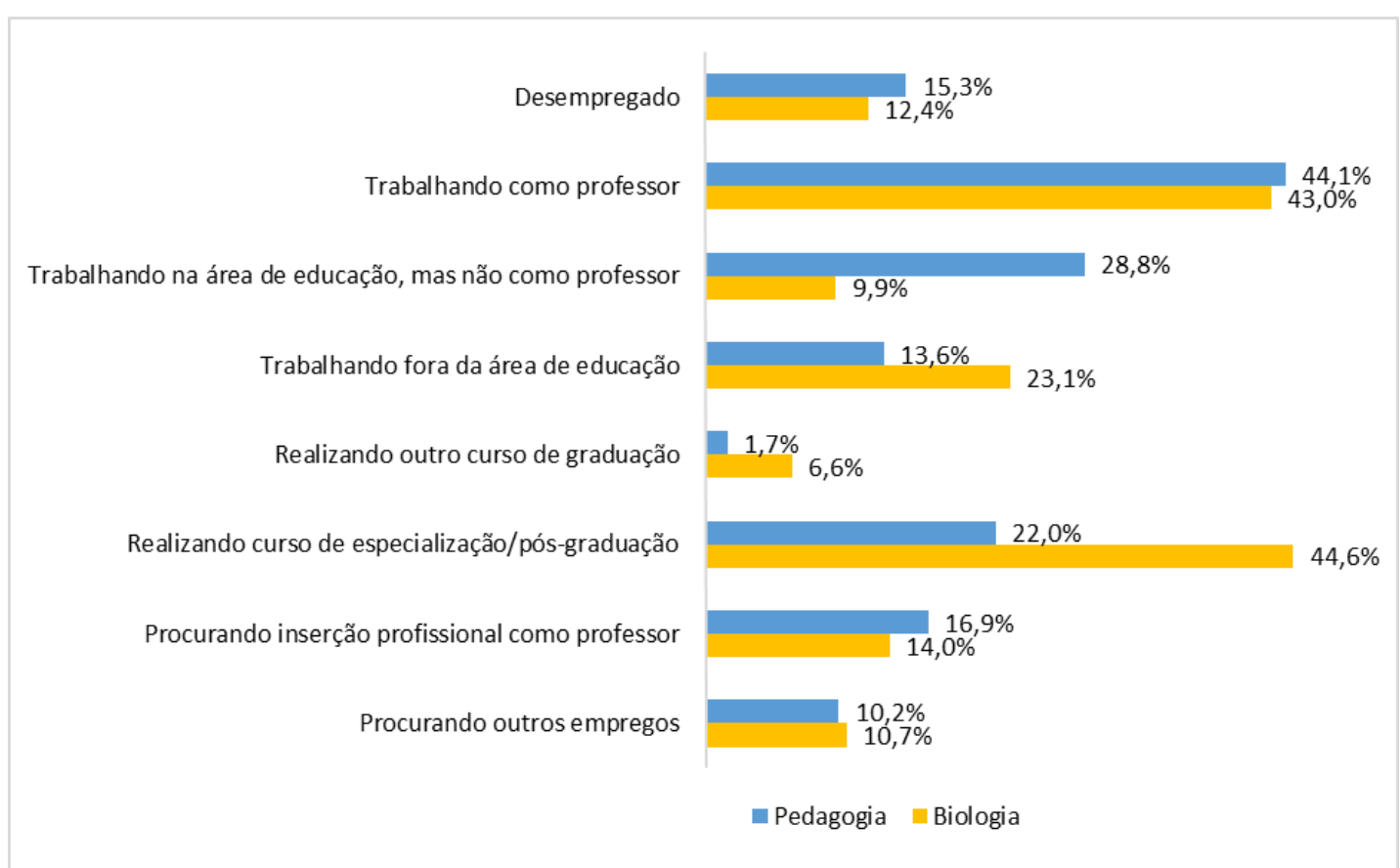

\section{Gráfico 6 - Situação após concluir a licenciatura}

Fonte: Elaborado pelo autor.

Nota: Pergunta com resposta múltipla e frequências com base no total de respondentes.

Trabalhando como professor aparece com 44,1\% e 43,0\% das respostas. Dentre os que disseram ter um trabalho na área de educação, mas não como professor, temos $28,8 \%$ na Pedagogia e $9,9 \%$ na Biologia, enquanto que aqueles 
trabalhando fora da área de educação perfazem $13,6 \%$ e $23,1 \%$, respectivamente. Portanto, a permanência na área educacional é maior entre os licenciados em Pedagogia $(72,9 \%)$ do que na Biologia $(52,9 \%)$, uma vez que o primeiro grupo desses profissionais pode atuar na regência de turmas, como docente, e em outras funções no âmbito escolar como supervisão e orientação pedagógica.

Destacam-se ainda a realização de cursos de especialização e pós-graduação pelos egressos (entre os que disseram estar trabalhando como professor esse índice atinge $26,9 \%$ na Pedagogia e $48,1 \%$ na Biologia) e a procura de empregos como professor ser maior do que a busca por inserção profissional fora da área de formação (Quadro 4). Um detalhamento sobre a formação continuada/qualificação profissional, bem como as motivações para sua realização, entre os professores iniciantes serão apresentados na próxima seção.

Quadro 4 - Situação após concluir a licenciatura Fonte: Elaborado pelo autor.

\begin{tabular}{|c|c|c|c|}
\hline \multicolumn{2}{|c|}{ Situação } & Pedagogia & Biologia \\
\hline \multirow{3}{*}{ Desempregado } & Realizando curso de especialização/pós-graduação & $11,1 \%$ & $33,3 \%$ \\
\cline { 2 - 4 } & Procurando inserção profissional como professor & $55,6 \%$ & $46,7 \%$ \\
\cline { 2 - 4 } & Procurando outros empregos & $22,2 \%$ & $26,7 \%$ \\
\hline \multirow{2}{*}{$\begin{array}{c}\text { Trabalhando } \\
\text { como professor }\end{array}$} & Realizando curso de especialização/pós-graduação & $26,9 \%$ & $48,1 \%$ \\
\cline { 2 - 4 } Trabalhando na & Procurando outros empregos & $3,8 \%$ & $7,7 \%$ \\
\cline { 2 - 4 } $\begin{array}{c}\text { área de } \\
\text { educação }\end{array}$ & Procurando inserção profissional como professor & $11,8 \%$ & $16,7 \%$ \\
\cline { 2 - 4 } & Procurando outros empregos & - & $8,3 \%$ \\
\hline
\end{tabular}

Fonte: Elaborado pelo autor.

Nota: Pergunta com resposta múltipla e frequências com base no total de respondentes.

Neri (2013), com base nos microdados do Censo Demográfico de 2010/IBGE, elaborou um ranking das perspectivas profissionais em função do salário, jornada de trabalho, taxa de ocupação e cobertura previdenciária de 48 carreiras universitárias, isto é, áreas que exigem formação em nível superior para atuação profissional. O autor constatou que 'Educação e formação de professores' apresenta uma taxa de ocupação de $94,13 \%$ ( $8^{\text {a }}$ posição), porém não especifica se foi considerado apenas postos de trabalho na área de formação. Quando a variável salário é tratada com peso diferenciado das demais qualidades trabalhistas e a alta jornada é tida como um problema, a taxa de ocupação cai para $82,3 \%$ (27 posição). 
$\mathrm{Na}$ presente pesquisa, os licenciados em Pedagogia e Biologia apresentam uma taxa de ocupação (disseram estar trabalhando) de $86,5 \%$ e $76,0 \%$, índices similares aos apontados com base no Censo 2010.

A identificação com o ofício docente, antes mesmo de concluir a formação inicial é um indicador de profissionalidade, à medida que considera experiências individuais ao longo da trajetória de escolarização e motivações pessoais como vocação e humanismo, para além da regulamentação da profissão. "Ponte entre aspectos pré-profissionais e profissionais propriamente ditos" a profissionalidade "evoca explicitamente a motivação, o sistema de valores e introduz no domínio profissional o que se origina no domínio privado" (COURTOIS, 1996, p. 172 apud LÜDKE; BOING, 2010, n.p.).

Sobre esse conjunto de representações e valores é importante diferenciar a profissionalização docente, que reúne definições e exigências para o exercício do magistério, tais como: a realização de um curso de nível superior, o domínio de conhecimentos específicos sobre o processo educacional e a regulação da atuação e da eficiência do trabalho por parte do governo.

Como afirmam Shiroma e Evangelista (2010, n.p.), diante das reformas do Estado calcadas na racionalidade técnica, enfatizou-se a necessidade de profissionalizar os servidores públicos e o termo profissionalização aparece “justaposto a conceitos como competência, eficiência, qualidade, autonomia, responsabilidade, accountability e avaliação no plano de uma nova gestão pública." Essas características e definições teóricas acerca da profissão foram operacionalizadas em questões com o uso da escala de Likert, a fim de se compreender as representações e a concordância com tais itens sobre a profissionalidade e o trabalho docente nos primeiros anos da carreira.

\section{2.}

\section{Tornar-se professor: Os iniciantes}

Como visto na seção anterior, os egressos do curso de licenciatura em Pedagogia e do curso de licenciatura em Ciências Biológicas de uma universidade federal na cidade do Rio de Janeiro, participantes dessa pesquisa, compreendem uma população jovem na faixa dos 25 aos 29 anos de idade $(58,2 \%)$ e predominantemente do sexo feminino (70,8\%). Dentre os quais $42,4 \%$ dos 
licenciados em Pedagogia e 50,4\% dos licenciados em Biologia nunca atuou no magistério ${ }^{27}$. Anteriormente, foi observado que embora nem todos os egressos atuem como professores, a taxa de ocupação para ambos os cursos é condizente com a média nacional informada no estudo de Neri (2013).

Nesta seção será abordada a entrada na carreira docente com uma análise das opiniões sobre a profissão; a continuidade da formação, o acolhimento, envolvimento e desempenho no trabalho, as motivações para o desenvolvimento profissional e ainda sobre as influências do processo de profissionalização do magistério, a fim de evidenciar os elementos que compõem a identidade do professor iniciante na carreira.

A caracterização de aspectos profissionais segundo as representações dos professores iniciantes inquiridos nessa pesquisa buscou evidenciar as possíveis homologias do campo (BOURDIEU, 2004), isto é, as especificidades e generalidades, as "semelhanças na diferença", segundo o tempo de atuação e, principalmente, entre os grupos da Pedagogia e da Biologia.

A inserção profisssional ${ }^{28}$ (Gráfico 7), forma de acesso ao mercado de trabalho após a conclusão da licenciatura, teve uma distribuição mais homogênea dentre as opções de resposta fornecidas, embora o concurso público tenha ficado em primeiro lugar para ambos os cursos. 'Estágio mais efetivação' surgiu de forma relevante dentre os comentários dos licenciados em Pedagogia (como já mencionado, alguns professores iniciam sua trajetória profissional antes de concluir a formação inicial, como auxiliares ou como normalistas).

\footnotetext{
${ }^{27}$ Essa constatação foi feita com base nas respostas à questão obrigatória "As próximas perguntas estão direcionadas ao trabalho como professor. Caso você tenha exercido a profissão por algum tempo ou esteja atuando no magistério selecione 'Continuar'. Se você não atuou no magistério, selecione 'Encerrar'.". Assim foi possível identificar um subgrupo dentre os egressos participantes da pesquisa, que se encaixam na categoria professor iniciante.

${ }^{28}$ Os resultados da presente pesquisa, em termos de inserção profissional nas redes educacionais vão ao encontro dos achados de pesquisas realizadas pelo Soced com enfoque na qualidade do ensino em escolas públicas e privadas. Para maiores detalhes consultar Xavier, Canedo e Brandão (2013).
} 


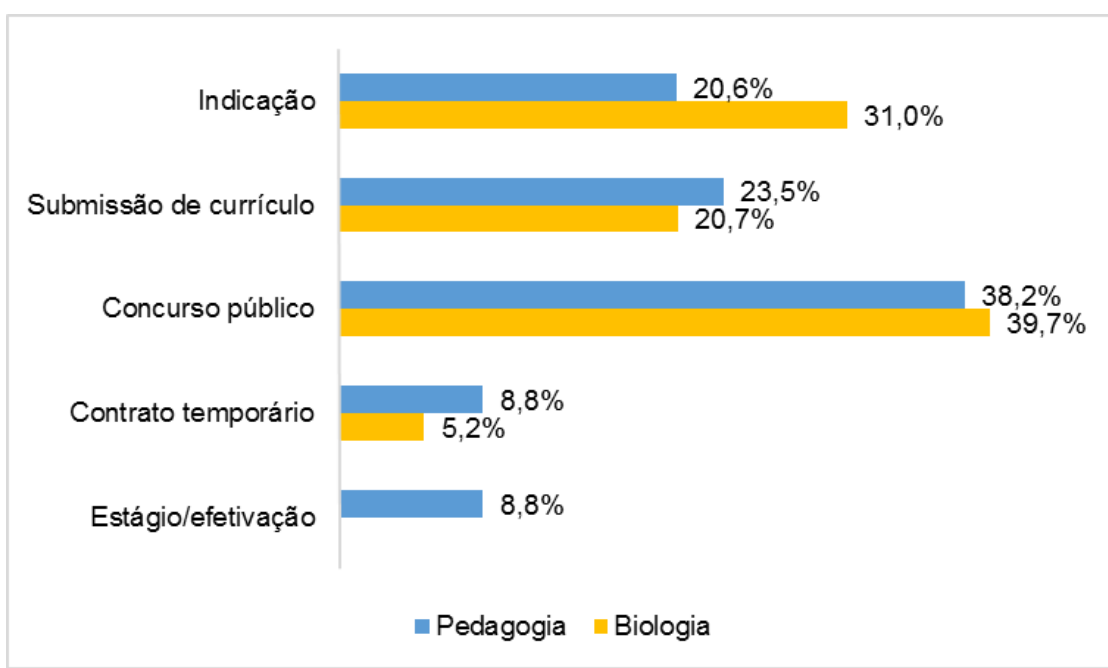

\section{Gráfico 7 - Formas de inserção no mercado de trabalho como professor}

Fonte: Elaborado pelo autor.

A distribuição desses profissionais em função da dependência administrativa do local de trabalho (Gráfico 8) revela que o setor público absorveu a maior parte dos professores, inclusive em mais de um posto de trabalho (mais de uma matrícula). Não será discutida a oferta e a demanda de professores entre as redes particular e pública, apenas observou-se que, dentre os participantes dessa pesquisa, a distribuição é bem similar com destaque para a rede municipal no caso dos formados em Pedagogia e os estabelecimentos privados de ensino regular para os formados em Biologia.

Particular preparatório/Cursinho

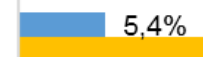

$12,3 \%$

Particular ensino regular

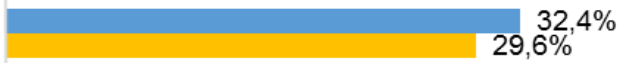

Público municipal

$18,5 \%$

Público estadual

$22,2 \%$

Público federal

$2,7 \% 7,4 \%$

Outro (especifique)

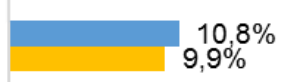

ฯ Pedagogia $\square$ Biologia

Gráfico 8 - Distribuição dos professores iniciantes em função da dependência administrativa do local de trabalho

Fonte: Elaborado pelo autor.

Nota: Pergunta com resposta múltipla e frequências com base no total de respostas. 
O aumento no atendimento da educação infantil, corroborado pela Meta 1 do PNE, as mudanças na carga horária do professor das séries inicias do ensino fundamental, conforme a Lei do Piso (BRASIL, 2008) - ambos, níveis de ensino a cargo das administrações municipais -, e a alta demanda de professores tanto para o setor de escolas e cursos preparatórios particulares, como para o ensino regular público - este último, em geral, uma atribuição preferencial das administrações estaduais - estão associados às percentagens de vagas ocupadas pelos professores iniciantes participantes dessa pesquisa.

A sobreposição de empregos público e privado ocorre para 13,8\% dos licenciados em Biologia, o que não ocorreu para os de Pedagogia. Na categoria 'Outro' foi observado o acesso à docência no nível superior privado por formados na Pedagogia e em escolas de ensino médio técnico por parte dos formados na Biologia. Algumas das respostas não puderam ser categorizadas quanto à dependência administrativa. Na correlação entre forma de inserção e o tipo de estabelecimento/rede de ensino, os dados sugerem que na rede particular há um processo seletivo para admissão dos professores, além da já esperada indicação e submissão de currículo, e ainda a efetivação de estagiários. Os contratos temporários são raros em ambas as dependências administrativas.

Embora não se tenha perguntado objetivamente sobre o primeiro emprego, a comparação com os estudos da UNESCO (2004) e (2009) fornece uma série histórica de dados. De acordo com a organização, há uma rápida inserção dos professores recém-formados no mercado de trabalho, especialmente nas escolas públicas. Em ambos os estudos, mais de $70 \%$ dos professores disseram ter começado a carreira docente ou trabalhar atualmente na rede pública de ensino. Como observado nesta investigação, pouco mais de 50\% dos respondentes dessa pesquisa possuem empregos públicos. Por se tratar de uma amostra muito inferior àquelas que produziram os dados apresentados pela UNESCO e devido ao viés de se considerar os egressos de uma única instituição formadora, acredita-se que a inserção profissional em função da dependência administrativa da escola para os professores formados nessa universidade seja diferenciada da média nacional. Uma hipótese é a atração do segmento educacional privado por esses profissionais, somado ao crescimento do setor, em número de matrículas e de estabelecimentos, entre os anos de 2005 e 2012, e a retração do número de estabelecimentos da rede pública no mesmo período (FENEP, 2013). 
Sobre o início da carreira docente, o tempo em relação à conclusão da graduação e a entrada no mercado de trabalho (Gráfico 9) revela que entre os licenciados em Pedagogia começam cedo, 61,8\% conseguiram seu primeiro emprego antes de concluir o curso e para $14,7 \%$ em menos de seis meses depois. Para os professores formados em Biologia, 24,1\% iniciam no primeiro emprego antes de concluir a graduação e $37,9 \%$ em até seis meses depois.

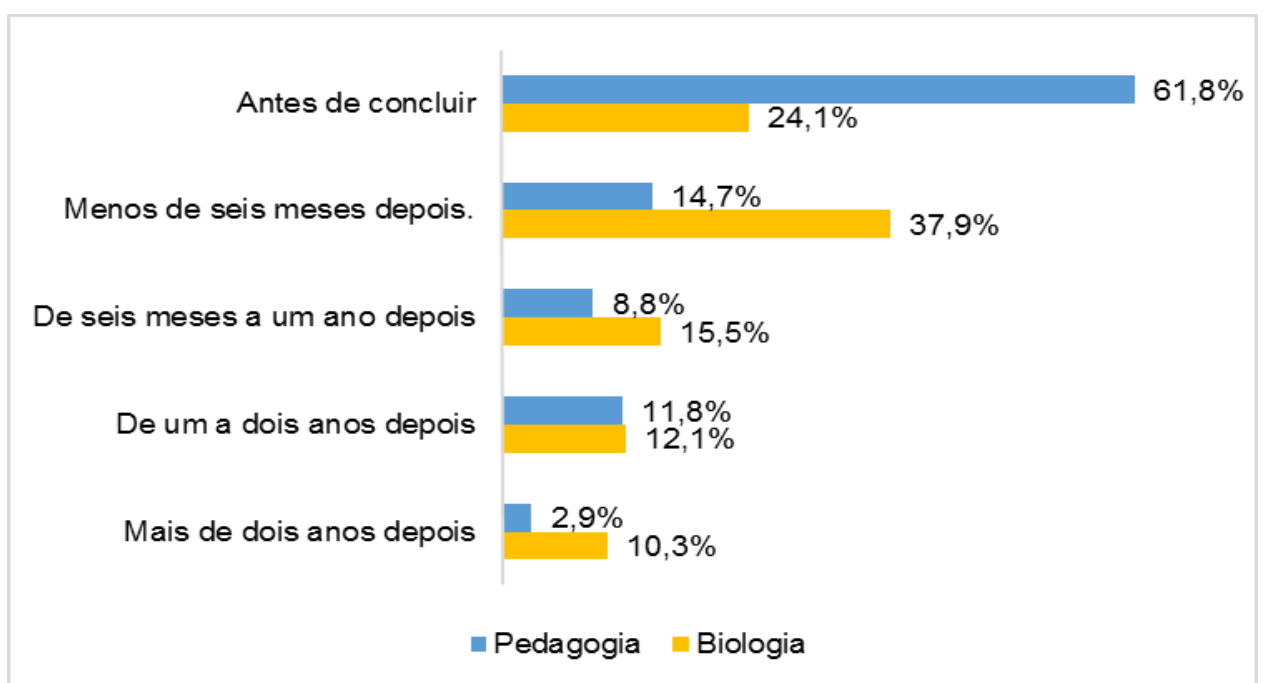

\section{Gráfico 9 - Tempo após concluir a licenciatura e o primeiro emprego como professor}

Fonte: Elaborado pelo autor.

Os dados vão ao encontro do constado pela UNESCO, embora a permanência, especialmente no emprego público, seja inconstante em função de problemas como a divisão da carga horária de trabalho em mais de uma unidade de ensino, a falta de recursos materiais e apoio/acolhimento institucional, a insatisfação e o estresse com a carreira. Os motivos de abandono da carreira, o grau de envolvimento com o trabalho, as formas de acolhimento e os principais sentimentos durante os primeiros anos como professor serão apresentados mais à frente.

O tempo de atuação profissional (Gráfico 10) apresentou distribuição homogênea para ambos os grupos de professores iniciantes, em função dos cursos de licenciatura concluídos e das categorias de resposta, as quais foram elaboradas em função no ciclo de vida profissional (HUBERMAN, 1992): fase de entrada na carreira (1 a 3 anos de docência) e fase de estabilização (4 a 6 anos de docência). Como o período de análise é extenso, houve uma dispersão do tempo de atuação 
e, como evidenciado anteriormente, alguns desses professores iniciam suas carreiras antes da formação mínima exigida.

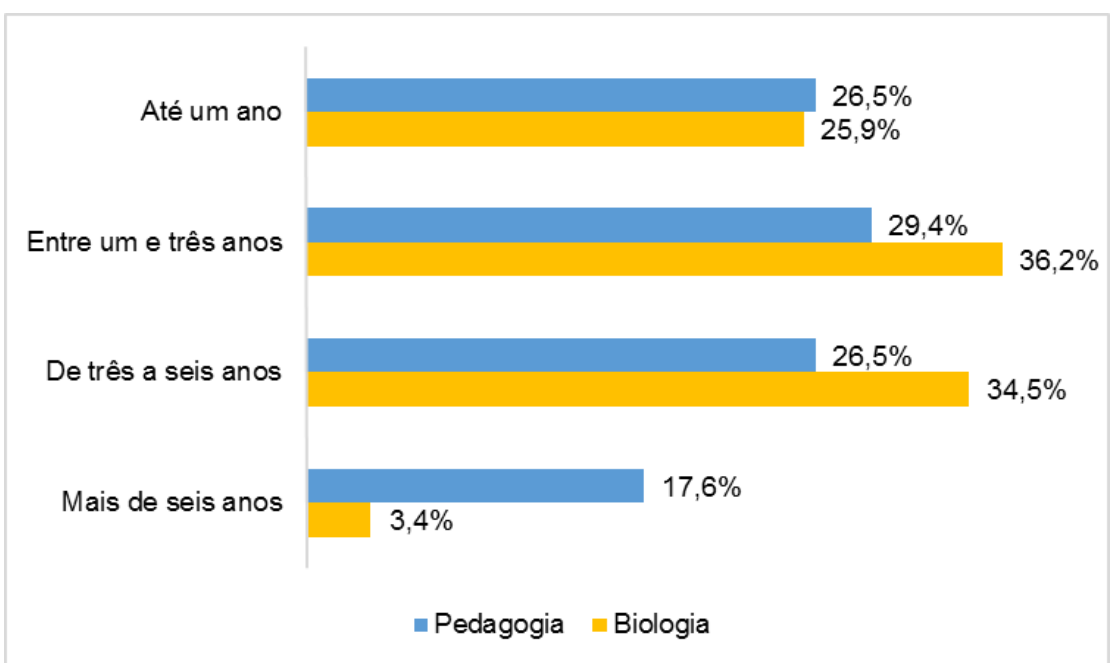

\section{Gráfico 10 - Tempo de atuação como professor}

Fonte: Elaborado pelo autor.

A decisão de se observar o desenvolvimento da profissionalidade docente $\mathrm{e}$ a incorporação de um habitus professoral pela imersão em contextos de trabalho colocou o modelo de ciclo de vida profissional, ou mais especificamente suas duas primeiras fases, como hipótese. Adotar tal orientação teórico-metodológica é seguir a flexibilidade sugerida por Huberman (1992) e corroborar com Oliverio (2014, p. 67) que buscou evitar um corte abrupto pela "marcação dos anos de carreira correspondentes às diferentes fases".

A ordenação de fases ao longo da vida profissional, pressupõe uma "continuidade" em que existem "zonas de interseção entre estes indivíduos, mas também zonas de diferença, sem que a fronteira entre as duas zonas seja nítida" (HUBERMAN, 1992, p. 54) e ainda com o entendimento de desenvolvimento profissional (MARCELO GARCÍA, 1995) e a valorização da profissionalidade (CONTRERAS, 2012) discutidos anteriormente.

O que coincide com a abordagem sociológica que articula processos identitários biográfico e relacional (DUBAR, 1997), para além das hipóteses psicanalíticas, na reconstrução de acontecimentos biográficos significativos no âmbito das atividades coletivas e relacionais: "Entre os acontecimentos mais importantes para a identidade social, a saída do sistema escolar e o confronto com o mercado de trabalho constituem actualmente um momento essencial na 
construção da identidade autónoma" (p. 113) e "A transação objectiva entre os indivíduos e as instituições é, antes de mais, aquela que se organiza à volta do reconhecimento e do não-reconhecimento das competências, dos saberes e das imagens de si” (p. 118).

Sobre a situação profissional, observa-se ainda que a distribuição dos professores iniciantes de acordo com o nível de ensino em que atuam (Gráfico 11) é tal que 35,4\% dos formados em Pedagogia atua no ensino fundamental (séries iniciais) e 25,0\% na educação infantil, enquanto os formados em Biologia concentram-se $46,7 \%$ no ensino fundamental (séries finais) e 37,8\% no ensino médio. Esse dado era de certa forma esperado, uma vez que consideramos a atuação profissional em função docente em sala de aula, cuja tendência geral é que os licenciados em Pedagogia assumam as turmas de pré-escola até o $5^{\mathrm{a}}$ ano do ensino fundamental e os licenciados em Biologia assumam as turmas do $6^{\mathrm{a}}$ ano do ensino fundamental até o $3^{\circ}$ ano do ensino médio.

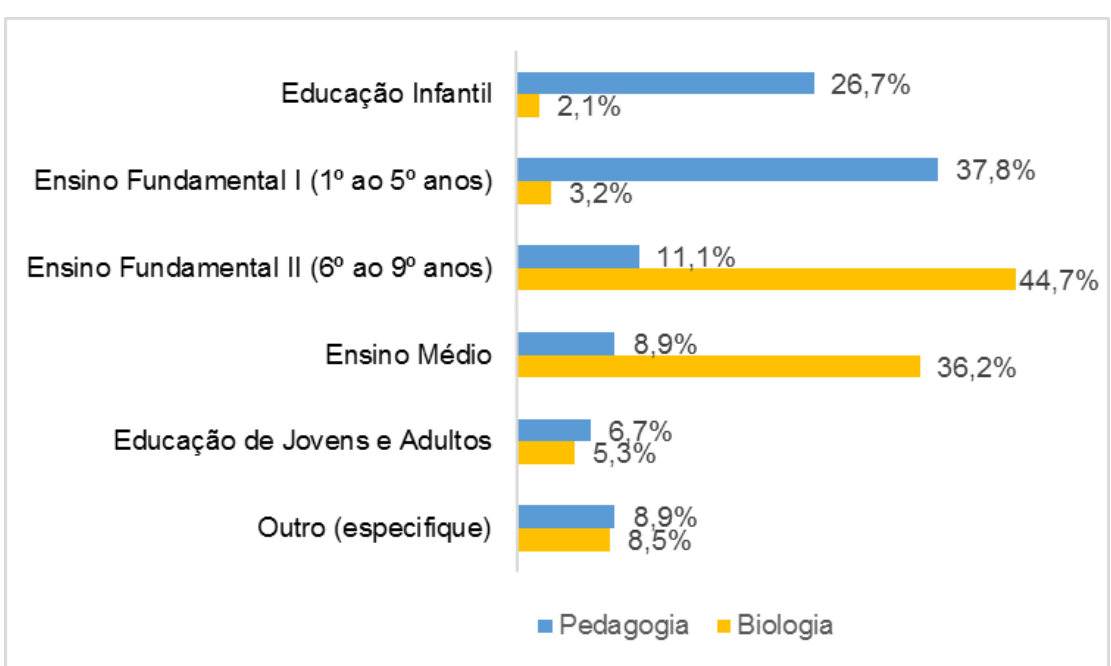

Gráfico 11 - Distribuição dos professores iniciantes em função do nível de ensino onde lecionam

Fonte: Elaborado pelo autor.

Nota: Pergunta com resposta múltipla e frequências com base no total de respostas.

Aqui verifica-se grande divergência com os dados de Maciente et al (2015), onde a distribuição dos licenciados em Pedagogia como professores (somados todos os níveis de ensino) totaliza 27,0\% e para os da Biologia atinge 19,4\%. As categorias profissionais com maiores participações de egressos desses cursos foram 'outros profissionais de ensino' (31,3\%) e 'ocupações administrativas' $(26,7 \%)$, respectivamente. Os autores destacam ainda "o elevado grau de emprego 
dos recém-formados em licenciaturas em trabalhos que não exigem escolaridade de nível superior (21\% em funções administrativas e 15\% em outras ocupações)." (MACIENTE et al, 2015, p. 15). De acordo com as informações disponibilizadas pelos autores, a atuação profissional como professor e nas demais funções escolares não aparecem entre as principais ocupações e 'outros profissionais de ensino' refere-se à funções desempenhadas fora do âmbito escolar.

Os respondentes dessa questão são aqueles que disseram em algum momento ter atuado ou estar trabalhando como professor, que é o objeto de discussão principal dessa pesquisa. A ocupação dos egressos em outras funções na estrutura escolar não foi detalhada e acredita-se que isso seja um viés a ser considerado.

A quantidade de empregos (Gráfico 12) é outro indicador de proletarização da profissão docente. A maioria dos professores iniciantes que participaram dessa pesquisa, $77,4 \%$ para Pedagogia e $56,1 \%$ para Biologia, no momento possuem apenas um emprego, ou matrícula, ou ainda posto de trabalho, de acordo com a terminologia dos economistas. O reconhecimento nos últimos anos da importância da dedicação integral do professor a uma unidade escolar e seu conjunto de alunos, bem como "o limite máximo de dois terços da carga horária de trabalho para o desempenho de atividades de interação com os educandos" (BRASIL, 2008, n.p.) são iniciativas que buscam melhorar a qualidade do ensino e da atuação profissional docente.

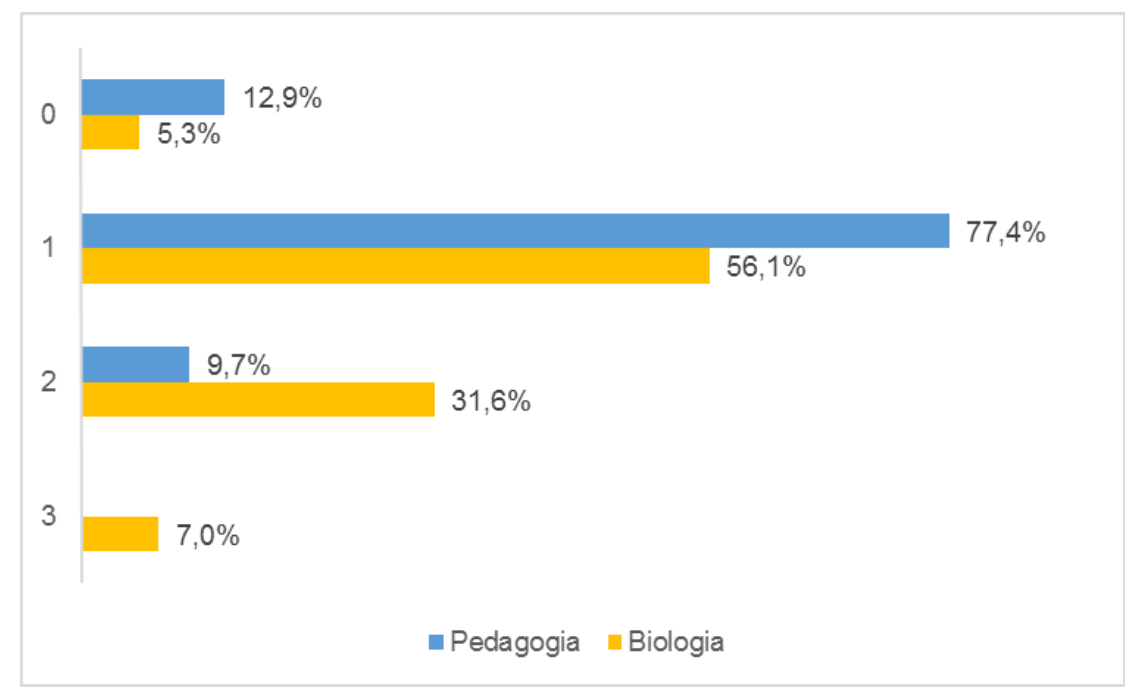

Gráfico 12 - Quantidade de empregos como professor

Fonte: Elaborado pelo autor. 
A informação de zero empregos refere-se àqueles professores que já atuaram, mas não trabalham mais como docentes por ter trocado de ocupação profissional. No caso dos professores especialistas, como os da Biologia, em função da existência de postos de trabalho com cargas horárias variadas, não raro há o acúmulo de dois ou mais empregos. De forma análoga, buscou-se caracterizar os primeiros anos de magistério em função da quantidade de horas trabalhadas por semana e a renda mensal. Nesses quesitos, valores iguais a zero referem-se aos professores que abandonaram a profissão.

A quantidade de horas por semana no local de trabalho (Gráfico 13) foi informada através de pergunta aberta, cujas respostas foram agrupadas em cinco categorias $^{29}$. As informações estatísticas não representam necessariamente a carga horária de qualquer cargo ou posto de trabalho do conjunto de professores que forneceram suas informações para a pesquisa.

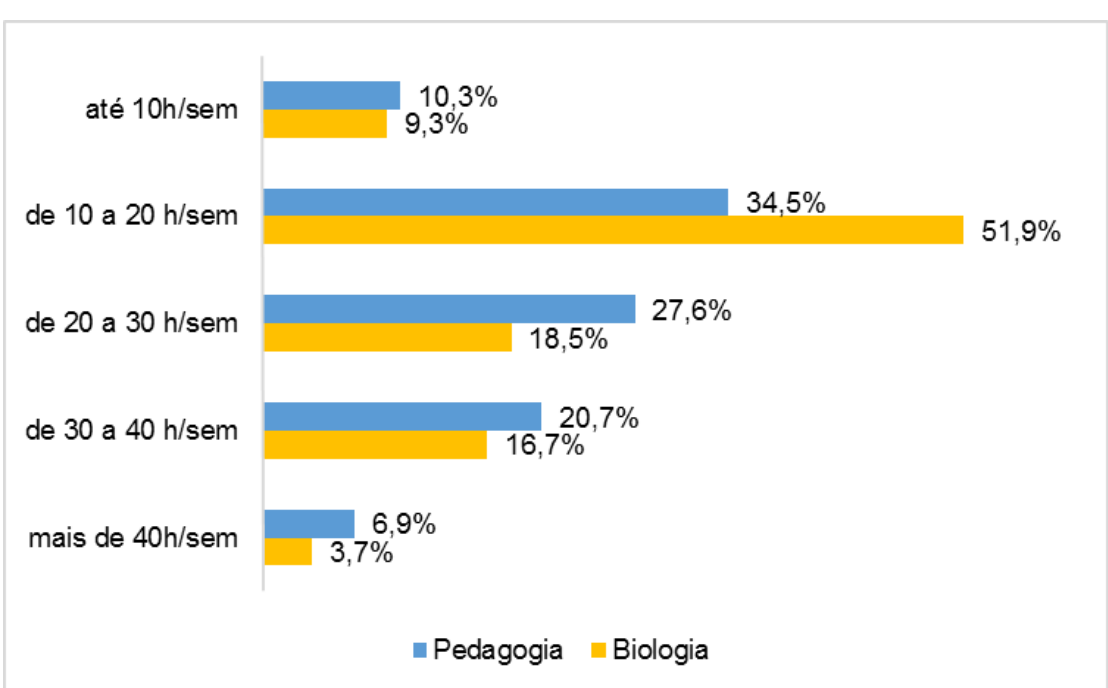

Gráfico 13 - Quantidade de horas por semana no local de trabalho

Fonte: Elaborado pelo autor.

A média de horas dispendidas por semana no trabalho foi 25,5h para Pedagogia e 22,7h para Biologia. A moda, isto é, a resposta com maior frequência, foi $20 \mathrm{~h}$ para ambos os grupos de professores. A distribuição em faixas foi homogênea na Pedagogia, sendo 10 a 20h/semana a com maior frequência de

\footnotetext{
${ }^{29}$ Foram eliminadas as respostas zero horas de trabalho por semana dos respondentes que disseram ter zero empregos, de modo a não alterar o cálculo da carga horária semanal média. Apenas dois respondentes que não trabalham mais como professores (zero empregos) informaram a quantidade de horas no local de trabalho e em casa.
} 
respostas com 34,5\% na Pedagogia e 51,9\% na Biologia. Alguns professores vivenciam a dupla ou tripla jornada de trabalho, ao manter mais de um posto de trabalho, aumentando assim a quantidade total de horas trabalhadas.

Quando indagados sobre a quantidade de horas por semana dedicadas ao trabalho docente em casa (Gráfico 14), a amplitude das respostas foi de zero a 40 horas em ambos os grupos de professores. A média foi de 8,2h para Pedagogia e 9h para Biologia. A moda foi de $8 \mathrm{~h}$ para ambos. Novamente as respostas foram categorizadas em faixas de horas.

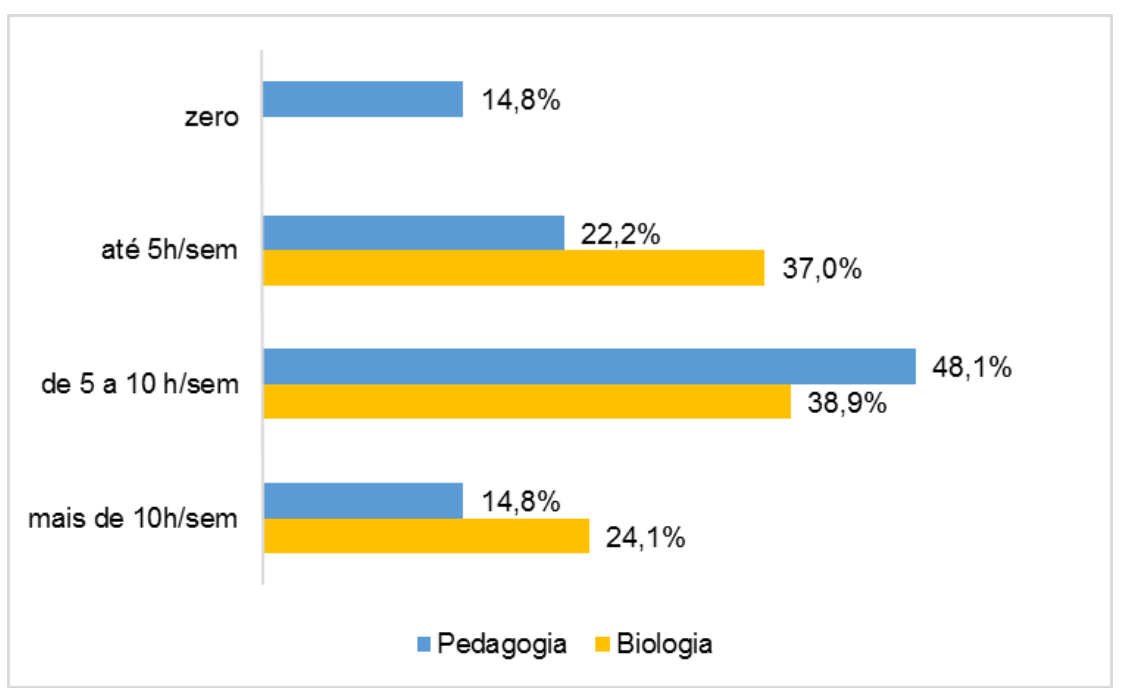

Gráfico 14 - Quantidade de horas por semana de trabalho feito em casa

Fonte: Elaborado pelo autor.

Diferentemente das questões anteriores, a informação zero horas de trabalho docente feito em casa, significa que tais professores não levam nenhuma parte de duas tarefas que não estejam vinculadas à interação com os alunos para fora do local de trabalho. Sem elementos que comprovem a realização de funções de planejamento, preparação e correção de avaliações, etc. no local de trabalho, pode-se levantar a hipótese de que uma parcela desses professores iniciantes não realiza tais funções e seu fundamento está no isolamento estrutural do trabalho docente (LÜDKE; BOING, 2012), como uma das características mais comuns e a falta de espaços coletivos e colaborativos para pensar e refletir sobre a prática pedagógica.

O exercício da ocupação dentro da sala de aula, entre quatro paredes, reforça a ideia de uma autoformação, ou um desenvolvimento profissional centrado predominantemente na prática do dia a dia, nas lições aprendidas individualmente, 
ao procurar vencer os obstáculos enfrentados, contando com a ajuda de um colega mais experiente ou recorrendo à lembrança dos exemplos, dos "bons professores", de sua própria infância. (LÜDKE; BOING, 2012, p. 432)

A renda mensal foi solicitada em questão aberta e as respostas foram categorizadas em faixas salarias (Gráfico 15) tomando como base o salário mínimo nacional de 2015, no valor de $\mathrm{R} \$ 788,00$. Embora a média ${ }^{30}$ seja afetada por valores extremos (maiores ou menores), sua apresentação é apenas ilustrativa diante da variedade de respostas, que incluem a soma de dois ou mais empregos. Também será apresentada a mediana, isto é, o valor de tendência central que divide um conjunto de dados ao meio. A média dos salários dos respondentes da Pedagogia foi de R \$2.276,00 e da Biologia foi de R 2.407,00. Já a mediana foi de $\mathrm{R} \$ 2.000,00$ para ambos. A faixa salarial com maior frequência para ambos os grupos (46,4\% na Pedagogia e 40,0\% na Biologia) foi a de até dois salários mínimos $(\mathrm{R} \$ 1.576,00)$.

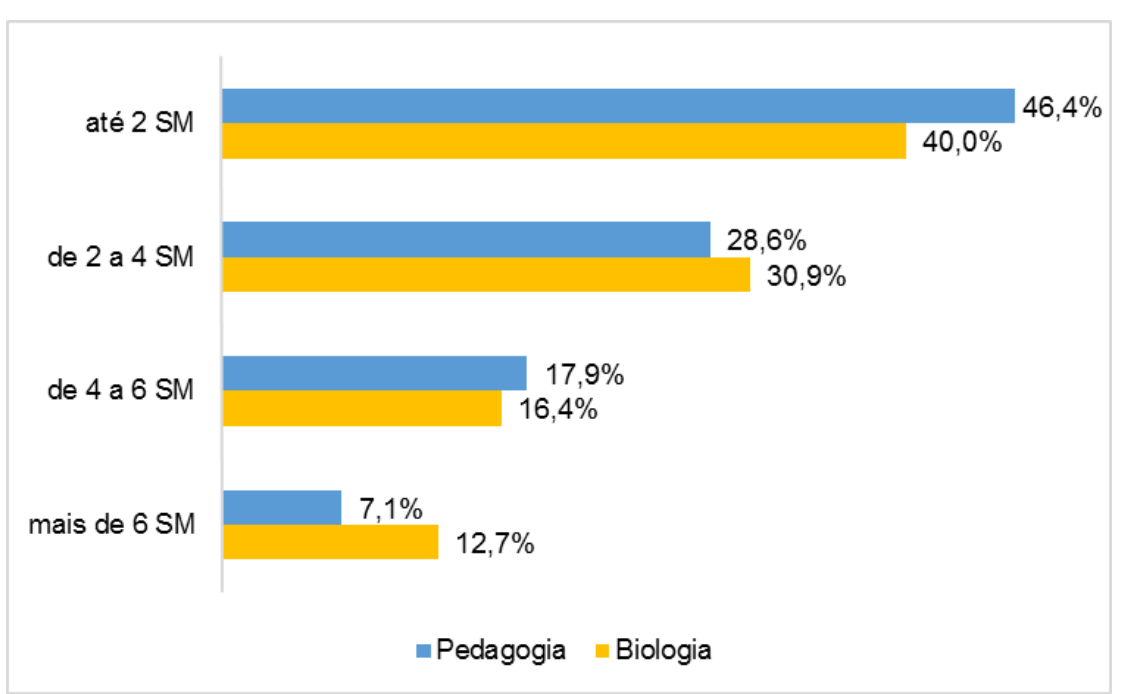

\section{Gráfico 15 - Renda Mensal como professor}

Fonte: Elaborado pelo autor.

Embora o relatório da UNESCO (2009), apresente as médias e medianas para os professores em função da dependência administrativa e o nível de ensino em que exercem sua atividade, toma-se para comparação o rendimento mensal médio da profissão 'Professores (Ed. Básica)' tal como informou a fonte dos

\footnotetext{
${ }^{30}$ As indicações salariais de um respondente da Pedagogia como professor no ensino superior e de um professor da Biologia na rede federal de educação básica não alteram significativamente a média, mas foram excluídos dos cálculos.
} 
dados (PNAD 2006) que foi de R\$927,00. No estudo de Negri e Silva (2015), com base nos dados da RAIS/MTE, para os anos de 2008 a 2013, são apresentados indicadores do comportamento das ocupações formais de nível superior no Brasil, após o período de crise mundial. Os autores demonstram que o crescimento dos salários acompanhou o crescimento do emprego, "especialmente entre os professores, de vários níveis, que foram os que apresentaram maior crescimento do salário médio no período" (NEGRI; SILVA, 2015, p. 25).

De acordo com os autores, 'Professores de nível superior na educação infantil e no ensino fundamental' recebiam $\mathrm{R} \$ 1.250,00$ em 2008 e $\mathrm{R} \$ 1.594,00$ em 2013, enquanto que 'Professores do ensino médio' recebiam R $\$ 1.306,00$ em 2008 e R \$ 1.639,00 em 2013. Dessa forma é possível estabelecer uma sequência temporal que ilustra o crescimento dos salários dos professores, chamando a atenção para as diferentes metodologias que produziram tais dados e a influência da lei do piso salarial do magistério (BRASIL, 2008) que estabelece correções anuais para o valor. Por fim, reitera-se o recorte teórico-metodológico desta pesquisa que permitiu a elaboração do valor médio geral de $\mathrm{R} \$ 2.364,00$ em 2015, cuja generalização não é possível por diversas razões já explicitadas anteriormente.

Em face aos indicadores de melhoria do rendimento médio dos professores da educação básica no país é preciso manter e aprimorar as políticas de valorização da profissão que ainda possui ganhos salariais inferiores às demais carreiras que exigem formação em nível superior. Além disso, o acúmulo de empregos e a busca por fontes de renda complementar fora setor educacional são estratégias comuns na categoria.

Ao se pensar o período de entrada na carreira docente e as múltiplas adaptações e aprendizados para o desenvolvimento profissional, seria desejável que o professor iniciante contasse com toda sorte de apoios e incentivos formativo-reflexivos para construir sua identidade e adequar-se às exigências da profissionalização, no sentido estrito da regulação para eficiência do trabalho.

Quando indagados sobre quais formas de acolhimento institucional receberam no primeiro emprego como professores (Gráfico 16), os itens mais frequentemente experimentados pelos respondentes da Pedagogia foram a 'apresentação da equipe pedagógica', para 83,3\%, seguido pela 'apresentação das dependências da escola', para 70,0\%. Já entre os respondentes da Biologia foram 
o 'recebimento de materiais, modelos de avaliações, livros, regimento, etc.', para $72,2 \%$, a apresentação da equipe, para $68,5 \%$, e a apresentação da escola, para $61,1 \%$.

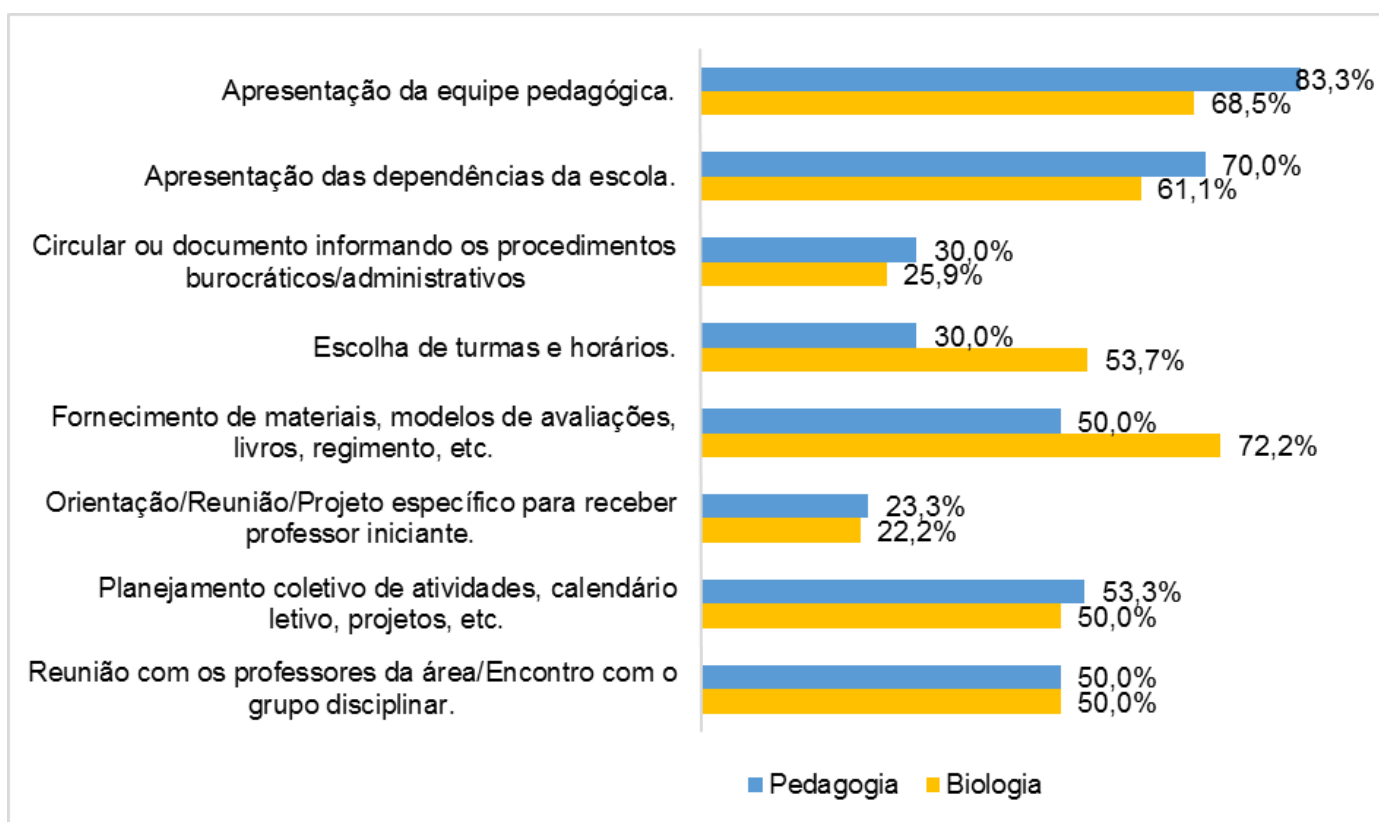

Gráfico 16 - Formas de acolhimento institucional experimentadas no primeiro emprego

Fonte: Elaborado pelo autor.

Os itens menos reportados por ambos foram o recebimento de alguma orientação por escrito do tipo 'circular ou documento informando os procedimentos burocráticos/administrativos', presente para apenas 30,0\% dos licenciados em Pedagogia e 25,9\% em Biologia, e o fornecimento de orientação específica para o professor iniciante, apontado por apenas $23,3 \%$ e $22,2 \%$.

Os demais itens foram vividos por cerca de metade dos participantes da pesquisa, o que indica a tendência do não fornecimento de quaisquer formas de acolhimento e orientação no primeiro emprego, a fim de desenvolver o trabalho colaborativo e a reflexão sobre a prática docente. Corrobora-se o evidenciado por diversos estudos (HUBERMAN, 1992; LÜDKE, 1996; VEENMAN, 1984) que os primeiros anos da carreira se caracterizam pela descoberta, adaptação e sobrevivência como estratégias para superar o abandono, a falta de apoio sistematizado e o choque de realidade, e ainda ultrapassar os desafios e dificuldades. 
A falta de clareza e de orientação para realização de tarefas cotidianas, como ensinar, lidar com diferenças de aprendizagem ou defasagem idade-série, selecionar e/ou elaborar materiais didáticos, lidar com o comportamento e desinteresse dos alunos, preencher dos diários e elaborar relatórios e outros documentos, e a praticamente ausência de informações específicas para o iniciante são flagrantes do isolamento profissional: o professor ao iniciar num emprego acaba tendo que descobrir por "ensaios e erros" (LORTIE, 1975 apud LÜDKE, 1996, p. 12), ao invés de contar com a orientação e o diálogo com professores mais experientes, que poderiam lhe mostrar alternativas e rumos a seguir sobre as incertezas de conteúdos, métodos e formas de lidar com os alunos e com novas exigências de qualidade e resultados.

Frequentemente são relatados na literatura sentimentos de abandono, por parte dos iniciantes, e a expectativa de que os recém-formados cheguem nos contextos de trabalho "prontos", por parte dos gestores, administradores educacionais e da própria equipe escolar. Da mesma forma, são comuns os relatos de insatisfação com a formação inicial, que não deu conta de preparar para as demandas do cotidiano de trabalho, levando ao chamado choque de realidade (VEENMAN, 1984). Os professores recém-formados, como afirma Gatti (2012b, n.p.) "encontram-se em uma condição em que estão legalmente habilitados para o exercício profissional, mas, não estão preparados de modo suficiente para o início de seu exercício profissional."

A suposta facilidade do trabalho de ensinar (LÜDKE; BOING, 2012) minimiza a complexidade da mediação e interação pedagógicas, que perpassam diferenças geracionais e motivacionais, além das expectativas de entrada numa carreira profissional e a imissão numa ocupação marcada por acumular o desejo e a responsabilidade de promover a transformação social. Quem está pronto ou acha fácil ser professor, especialmente no início da carreira?

Freitas (2000) verificou o esforço de professores iniciantes em atender e superar as adversidades, a fim de provar suas habilidades e competências e, assim, sobreviver e alcançar algum reconhecimento dos professores mais antigos e demais profissionais da escola onde trabalham. A autora observou junto aos seus informantes que o processo de escolha de escolas e a atribuição de turmas não pondera a preferência ou a eficiência do professor, mas a hierarquia por tempo de serviço. Esse mecanismo oficioso de distinção, marca posições e privilégios 
diferenciados nas escolas. A autora afirma com base num clássico estudo americano sobre a socialização do professor que o iniciante, desde o primeiro dia de trabalho, tem as mesmas tarefas que um professor "antigo" e que as dificuldades não lhe são apresentadas de forma gradativa (cf. LORTIE, 1975 apud FREITAS, 2000), como em outras profissões onde tarefas mais complexas são direcionadas a profissionais mais experientes.

De acordo com Corrêa (2015, p. 146) “o que prevalece na distribuição das turmas pelos professores é a necessidade das escolas, independentemente do perfil ou de experiências prévias dos professores" o que também foi observado por Oliverio (2014). No entanto, os próprios professores iniciantes tomam como desafio, "prova de iniciação" nos termos de Freitas (2000) e algum senso de competitividade de acordo com Corrêa (2015), o choque de realidade e as dificuldades de aprendizagens dos alunos. Alguns tendem a assumir tais dificuldades em função de sua falta de experiência ou segurança e não problematizam a atribuição de turmas com "alunos difíceis" e a falta de uma cultura colaborativa (LIMA, 2004).

Por outro lado, Papi e Martins (2010, p. 51) indicam que estudos com "professores iniciantes relacionados ao sucesso escolar, ou considerados bemsucedidos, mostram-se quase como silêncios no campo investigativo da educação". Os debates sobre professores bem-sucedidos (PAPI, 2011a; 2011b) e a realização de trabalho colaborativo na educação (DAMIANI, 2008) são fundamentais para a identificação de experiências positivas de iniciação na carreira, formas de acolhimento institucional e desenvolvimento profissional.

Sobre esse embate com a realidade de trabalho nas escolas e salas de aula, em contraste com as expectativas e desejos para o exercício da docência e a formação recebida para tal, Moura (1998) apresenta uma lista não exaustiva de questionamentos feitos pelos iniciantes sobre: a empregabilidade ou não dos ensinamentos recebidos e sua adequação para a prática de ensino, a capacidade de lidar com as dificuldades de aprendizagem e as questões de comportamento e disciplina dos alunos, a suficiência do estágio para articular teoria e prática, a qualidade da formação e as condições de trabalho frente à necessidade de reflexão e atualização profissional.

A atualidade desses pontos, apesar de passadas quase duas décadas desde a realização de sua pesquisa, também na cidade do Rio de Janeiro, converge com as 
observações de Veenman (1984), que também pondera a passagem de tempo entre as pesquisas por ele analisadas desde 1960 até meados da década de 1980 e questões contextuais e conjunturais adjacentes: rápidas alterações nos sistemas educacionais, nas possibilidades de inserção no emprego e no mercado de trabalho.

Parte dessas mesmas dificuldades e choques com a realidade foi observada em outras pesquisas empíricas feitas com professores iniciantes no Brasil, nos últimos 16 anos (período igualmente, ou ainda superior, em mutações nas relações de trabalho, no uso de ferramentas e suportes educacionais, bem como no papel e nas exigências do professor): Corsi (2005), Mariano (2006), Cancherini (2010), Furlan (2011), Reis (2011), além das citadas anteriormente, Freitas (2000), Lima (2004), Oliverio (2014) e Corrêa (2015). Os achados e tensões evidenciados em tais estudos compuseram itens que foram avaliados pelos respondentes dessa pesquisa, a fim de ponderar as representações sobre a identidade profissional, considerando as mudanças e permanências, ao longo das últimas décadas, no trabalho e ação docentes.

Corrobora-se com outro alerta de Veenman (1984, p. 167, tradução feita pelo autor):

\begin{abstract}
tais problemas não podem ser atribuídos exclusivamente às características pessoais dos professores iniciantes, às características situacionais do local de trabalho, e às deficiências na formação de professores. Naturalmente, estes fatores devem ser reconhecidos, mas os resultados também apontam para fatores além daqueles da pessoa individual, escola, programa de formação de professores, e local de trabalho. Fatores intrinsecamente associados com a tarefa de ensinar um grupo de estudantes, com o ensino como uma profissão e com a influência desta profissão sobre a pessoa do professor, devem ser considerados também, se se procura soluções para estes problemas.
\end{abstract}

A construção da identidade como professor passa pela vivência de sentimentos conflituosos e contraditórios, não raro impossíveis de serem explicadas por um modelo ou hipótese teórica. As tentativas de compreender a função docente moderna e os caminhos da profissão e da profissionalidade do professor exigem um complexo esforço teórico-analítico como demonstram Dubar (1997) e Lüdke e Boing (2004). Além de complexo, faz-se necessário enfatizar as mudanças culturais e a dinâmica com que são percebidos e valorados 
características e requisitos formativos, aqueles relativos ao desenvolvimento e à regulação das atividades profissionais.

Alguns desses sentimentos, mais intensos nos primeiros meses ou anos de trabalho como professor, foram listados e apresentados com a intenção de se identificar os mais comuns (Gráfico 17) dentre os professores iniciantes sujeitos dessa pesquisa. Como dito anteriormente na descrição da elaboração do questionário, foram apresentados dois conjuntos de sentimentos e foi solicitado aos respondentes que marcassem até duas opções em cada conjunto. A lista, não exaustiva e não mutuamente excludente, aparentemente cobriu os principais sentimentos, uma vez que foram feitos apenas seis outros registros, tais como estresse, desrespeito e frustração.

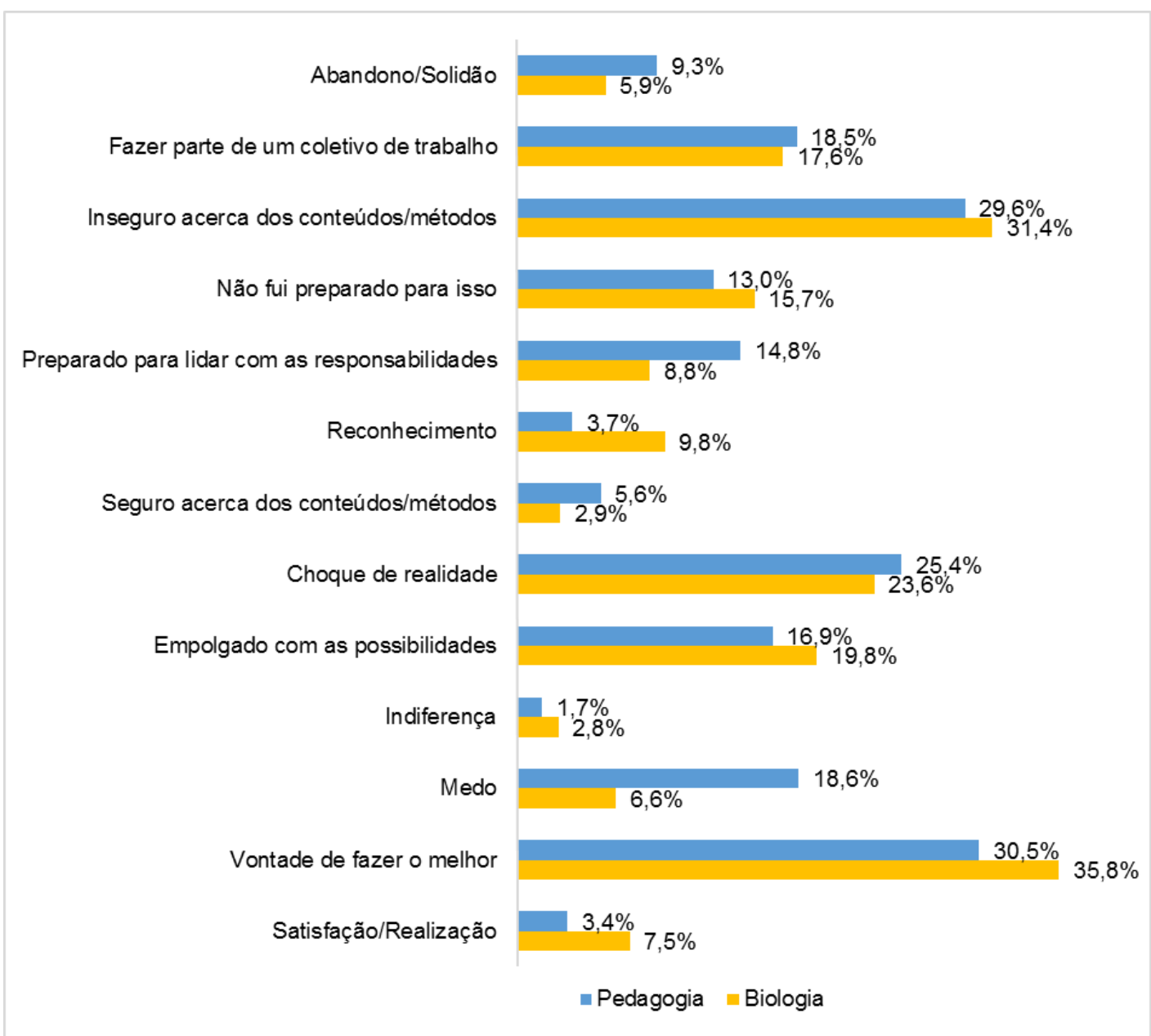

Gráfico 17 - Sentimentos mais comuns nos primeiros meses/anos na carreira docente

Fonte: Elaborado pelo autor.

Nota: Pergunta com resposta múltipla e frequências com base no total de respostas. 
Os três mais citados para ambos os grupos foram 'vontade de fazer o melhor', 'inseguro acerca dos conteúdos/métodos' e 'choque de realidade'. Apesar das inseguranças relativas aos saberes curriculares e aos saberes didáticos e do embate de expectativas com as condições reais de trabalho, os professores iniciantes participantes dessa pesquisa vivenciam a crença nas finalidades do seu trabalho através do otimismo e a da busca em realizar o melhor. Fica uma ambiguidade se tal sentimento é expresso na realização do "melhor possível", no sentido de nivelar por baixo o trabalho e as decisões e estratégias que os professores mobilizam diante das múltiplas realidades e dificuldades do campo, ou se indica a consciência dos limites do possível diante das condições e recursos.

Ao choque de realidade e à insegurança do início da carreira, muitas vezes associados ao isolamento e à desmotivação, é possível vincular a perda de autonomia e a intensificação do trabalho dos professores, tal como problematizam Apple e Jungck (1990, p. 156 apud NÓVOA, 1995, p. 24):

\begin{abstract}
A intensificação leva os professores a seguir por atalhos, a economizar esforços, a realizar apenas o essencial para cumprir a tarefa que têm entre mãos; obriga os professores a apoiar-se cada vez mais nos especialistas, a esperar que lhes digam o que fazer, iniciando-se um processo de depreciação da experiência e das capacidades adquiridas ao longo dos anos. A qualidade cede o lugar à quantidade [...] Perdem-se competências colectivas à medida que se conquistam competências administrativas. Finalmente, é a estima profissional que está em jogo, quando o próprio trabalho se encontra dominado por outros actores.
\end{abstract}

O envolvimento com o trabalho parece ir ao encontro de razões idealísticas: a necessidade de sobrevivência ao mundo capitalista, a crença nas finalidades humanísticas da educação, o comprometimento ético com a atividade pedagógica e o vínculo afetivo criado com os alunos, conforme observado por Lelis (1996, p. 146, grifo meu) e que ainda pondera "a presença de compromisso profissional recheado por afetividade que não se confunde com a maternidade ou com o trabalho doméstico".

Os sentimentos são marcados por contradições individuais e coletivas, em função das experiências e trajetórias de socialização, como também foi observado por Nascimento (2012). Nas investigações sobre professores iniciantes costumam ser apresentados dificuldades conjunturais/ contextuais, mas também parece haver um grande entusiasmo apesar das incertezas profissionais e pedagógicas, somado às diferenças entre ambientes de trabalho mais ou menos receptivos. Huberman 
(1992, p. 39) aponta que o aspecto de descoberta permite aguentar o sentimento de sobrevivência e que aquele "traduz o entusiasmo inicial, a experimentação, a exaltação por estar, finalmente, em situação de responsabilidade (...) por se sentir colega num determinado corpo profissional".

A vontade de fazer o melhor como o sentimento mais lembrado por ambos os grupos de professores indica resiliência e tomada de consciência ${ }^{31}$ sobre a (crise de) identidade do professor (cf. SILVA; CHAKUR, 2009). Nesse sentido, corrobora-se com Guimarães (2006) que insere a profissionalização do magistério em um processo que transforma uma ocupação em atividade desenvolvida não por diletantismo, mas de acordo com um código deontológico. Características que começam a emergir a partir da segunda fase do ciclo de vida profissional proposto por Huberman (1992) com a consolidação de uma cultura profissional e institucional, um repertório de práticas e saberes desenvolvidos e mobilizados para resolução dos problemas que se apresentam no cotidiano de trabalho.

A proximidade do percentual de respostas entre 'empolgado com as possibilidades' e 'não fui preparado para isso' sugere o comprometimento ético com as regras e finalidades da profissão, mas reitera a recorrência de inadequação da formação universitária e a carência de programas e políticas específicas para o início da docência (cf. GATTI, 2012a; 2012b). Também foi possível observar que, para o conjunto de professores participantes dessa pesquisa, 'indiferença', 'satisfação/realização' e 'reconhecimento' receberam os menores valores percentuais como sentimentos mais presentes no início da carreira, o que vai ao encontro dos diferentes começos em função da diversidade de subcampos ou realidades escolares (cf. NASCIMENTO, 2012; OLIVERIO, 2014) e à variedade de formas de "construção do seu eu profissional" (MARCELO, 2009, p. 11, grifo do autor).

Desde os primeiros anos de trabalho, o iniciante percebe a necessidade de complementar a renda. Dentre os iniciantes formados na Pedagogia, 22,6\% possuem outra atividade remunerada e entre os respondentes da Biologia esse índice atinge 31,6\% dos professores. O magistério é tido como a principal fonte de rendimentos para $87,1 \%$ e $78,9 \%$. As atividades de complementação de renda

\footnotetext{
31 A abordagem da teoria piagetiana sobre a tomada de consciência é uma chave de análise que extrapola as discussões sobre a profissão docente no âmbito dessa pesquisa.
} 
variam entre atividades de pesquisa (apoio técnico, bolsistas de mestrado e doutorado), aulas particulares, coordenação e orientação pedagógicas, passando por consultorias, comércio e prestação de serviços.

Por outro lado, o investimento de tempo em paralelo ao magistério para realização de algum curso de formação continuada ou qualificação profissional se faz rotina para $45,2 \%$ dos professores iniciantes formados em Pedagogia e para 33,3\% dos formados em Biologia.

As motivações mais frequentes que levam os professores a realizar tal investimento (Gráfico 18) são: o 'desenvolvimento intelectual' por unanimidade na concordância total entre os professores da Pedagogia e para 94,4\% dos professores da Biologia, seguido pelo 'aumento de salário/progressão na carreira' com 57,1\% de concordância total na Pedagogia e 77,8\% na Biologia. Em geral, portanto, a maioria dos respondentes concordou totalmente com todas as motivações listadas e enxergam uma possibilidade de valorização profissional simbólica e real na obtenção de um título e no incremento na renda.

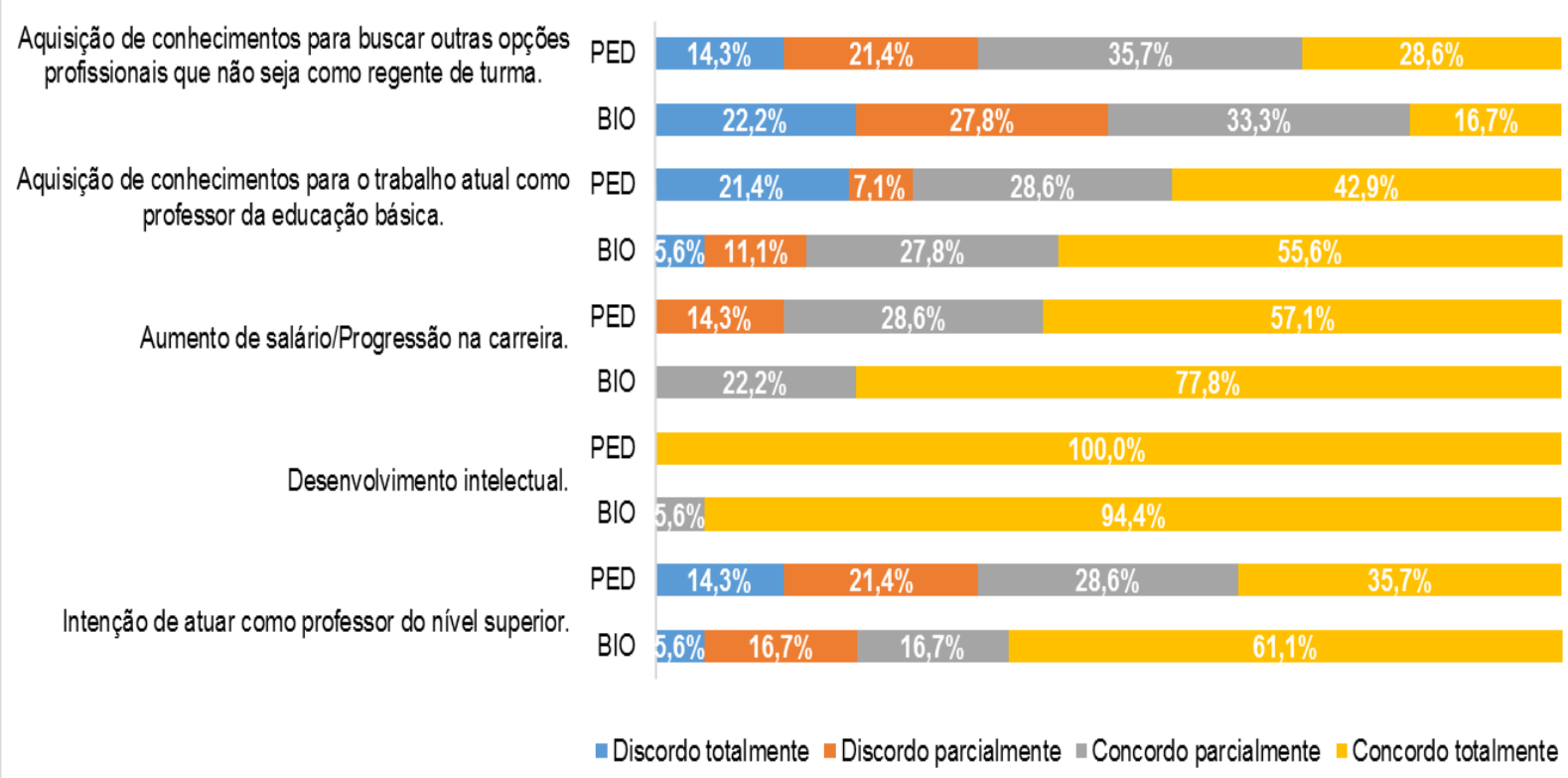

Gráfico 18 - Motivações para realização de curso de formação continuada ou de qualificação profissional

Fonte: Elaborado pelo autor.

Houve discordância no item 'aquisição de conhecimentos para atuar em outras funções que não como professor regente' (maior na Biologia) e nos itens 
'aquisição de conhecimentos para o trabalho atual como professor' e 'intenção de atuar no nível superior'. Nestes casos a maior rejeição à tais motivações para formação continuada ou qualificação profissional veio da Pedagogia. Fica a hipótese de que tais professores enxerguem nesses cursos oportunidades de deixar o trabalho em sala de aula e assumir outras funções no universo escolar da educação básica. Entre os professores da Biologia nota-se grande aspiração pela docência no nível superior, através dos $61,1 \%$ que concordaram totalmente com essa motivação. Outro destaque é o fato dos cursos realizados pelos respondentes serem mais voltados para o trabalho atual em sala de aula do que outras funções, apesar da rejeição total de 21,4\% na Pedagogia e 5,6\% na Biologia.

Entre os iniciantes formados em Pedagogia foram citados cursos de idioma, filosofia, poesia, especializações em psicopedagogia, administração e supervisão escolar, orientação educacional e pedagógicas, conselho escolar, formação de professores na perspectiva da inclusão, curso sobre séries iniciais oferecido pelo Colégio de Aplicação da UFRJ, curso de tutor para ensino à distância, e ainda, mestrado em educação. Já entre os iniciantes formados em Biologia foram citados cursos de divulgação científica, gestão ambiental, formação continuada para professores, especialização no ensino de ciências, residência docente no Colégio Pedro II, bem como, mestrado profissional em ciências ambientais, mestrado em ensino de biologia, mestrado profissional em formação científica para professores de biologia, mestrado e doutorado em educação, doutorado em educação em ciências e saúde, doutorado em ecologia.

Tais respostas permitem a inferência que, entre os respondentes, há uma preocupação de continuidade dos estudos em aspectos formativos e reflexivos para o exercício profissional da docência (maior entre os respondentes da Biologia do que da Pedagogia) na educação básica, em função dos tipos especializações e cursos em nível de mestrado e doutorado voltados para o ensino de biologia/ciências e a participação em um programa de iniciação à docência. A presença de cursos e capacitações que possibilitem a realização de outra atividade remunerada, também aparece, inclusive de forma declarada, para deixar a sala de aula: "[a motivação para realizar esse curso é] atuar como psicopedagoga" [P91]. Conforme disseram alguns desses professores, dentre outras motivações foram apresentadas: "Atuar na pós-graduação" [B14], "Pesquisar e conseguir fortificar um campo ainda pouco explorado; auxiliar na compreensão da formação de 
professores" [P44] e "A intenção de aprofundar academicamente em questões vividas no cotidiano da docência." [B66].

Sobre o abandono da profissão $29,0 \%$ dos professores iniciantes formados na Pedagogia já tentaram abandonar a carreira docente e 19,4\% não trabalham mais como docentes. Entre os formados na Biologia, 23,2\% já tentaram abandonar e $12,5 \%$ não trabalham mais como professores.

Aos respondentes que não atuam mais como professores foi solicitado seu posicionamento sobre os principais motivos alegados por ex-professores para justificar a saída do magistério (Gráfico 19). O restrito número de respondentes da questão (13 casos) compromete a identificação de tipos, ou a prevalência de algum item dentre as opções de resposta, portanto a leitura desses dados deve ser cautelosa. Além disso, é apresentado o observado de respostas e não a frequência simples das mesmas em valores percentuais.

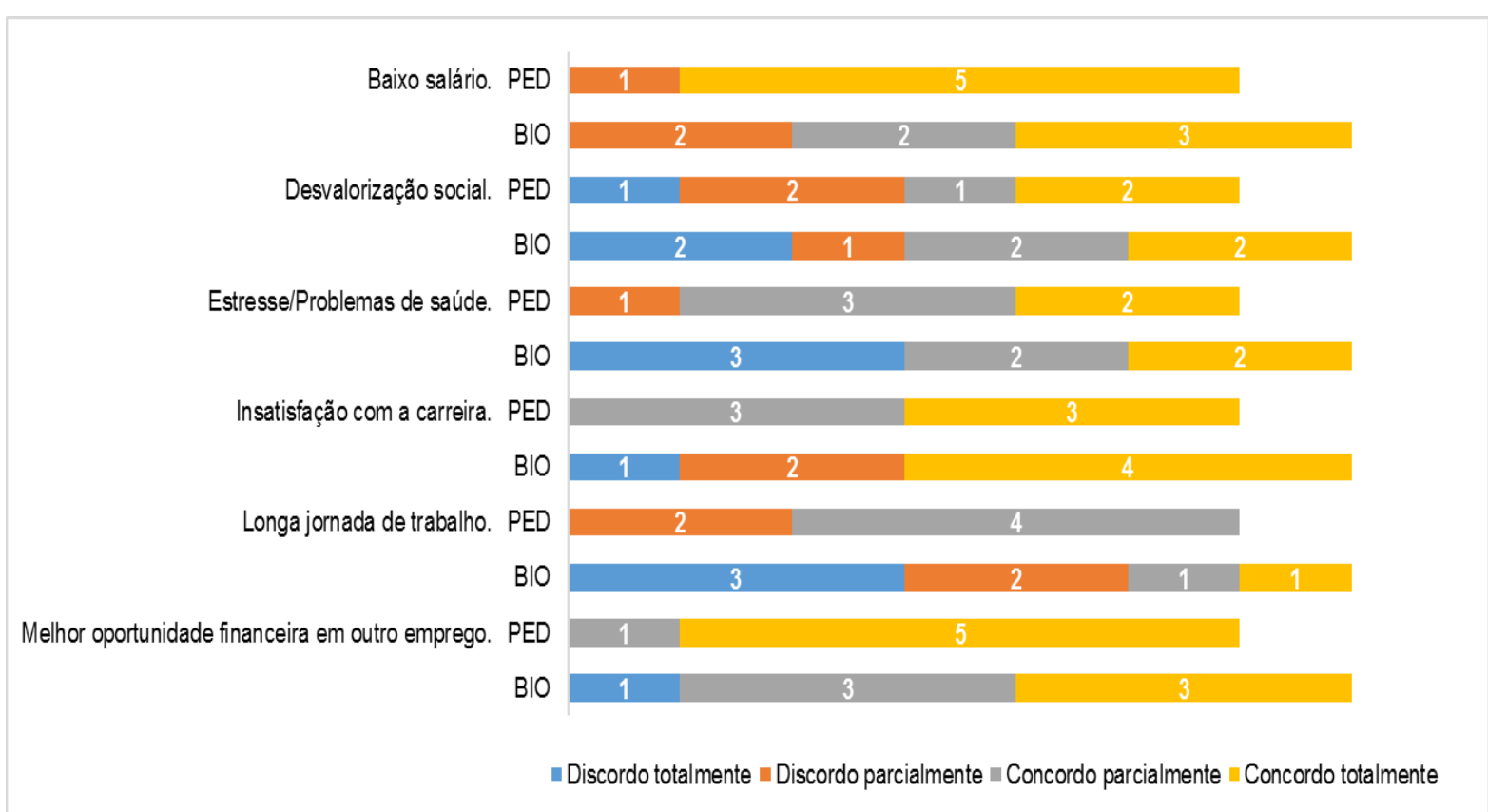

\section{Gráfico 19 - Motivações para o abandono do magistério}

Fonte: Elaborado pelo autor.

Os licenciados em Pedagogia tiveram um comportamento mais coeso, quase sem divergências na distribuição entre aqueles que concordam ou discordam dos seis itens listados. A concordância total para cinco em seis respondentes foi para os itens 'baixo salário' e 'melhor oportunidade financeira em outro emprego', seguido de concordância com 'insatisfação com a carreira' e 'estresse/problemas 
de saúde'. Já os licenciados em Biologia manifestaram grande divergência de opinião em todos os motivos apresentados. Houve concordância total para quatro em sete respondentes para o item 'insatisfação com a carreira', seguido de concordância com 'melhor oportunidade financeira me outro emprego' e 'baixo salário'. Em dois itens a discordância total para 'estresse/problemas de saúde' e 'longa jornada de trabalho' é relatada para três dos sete professores que abandonaram a carreira. 'Desvalorização social' foi uma categoria que não evidenciou preferências entre nenhum dos dois grupos de ex-professores, tendo apresentado distribuição homogênea das respostas entre discordo e concordo.

Entre motivos pessoais e profissionais e as interseções entre esses dois conjuntos, parece haver algum consenso sobre a contrapartida dos salários para o exercício de um trabalho. Recuperando a rejeição para a afirmativa 'A realização de um curso de licenciatura e a atuação como professor da educação básica conferem um aumento de prestígio social e realização profissional.', superior a $65 \%$ dos egressos dos dois cursos participantes dessa pesquisa (Gráfico 5), assume-se que o grau de desvalorização da profissão docente é alto a ponto de não caracterizar o abandono da mesma, pois é tomada como constituinte da ocupação. A não identificação de um prestígio ou fator de distinção social como nas carreiras imperiais, dada a exigência de formação em nível superior, e o senso comum de uma ocupação estável, porém retratada pela instabilidade e incerteza, denunciam mais um sinal de que a ocupação docente não apresenta o status de profissão, ou não concluiu o processo de profissionalização, ou ainda, alternativamente, se encaixa na chamada precarização do trabalho docente (MARIN, 2010).

\section{3.}

\section{A busca pelos saberes profissionais dos professores}

$\mathrm{Na}$ tentativa de identificar o que e como pensam os professores iniciantes sobre os atributos que caracterizam a atividade do magistério/docência como atividade profissional, foi solicitado que eles se posicionassem sobre alguns itens. A lista foi elaborada conforme os descritores da profissionalidade (ROLDÃO, 2005) e a discussão sobre profissão e profissionalização (DUBAR, 1997; GUIMARÃES, 2006) e trabalho docente (BRZEZINSKI, 2014; LÜDKE; BOING, 2010). Também foi constituída com base na tradição sociocultural que 
associa o caráter de vocação/missão para o exercício do magistério, assim como a afinidade para lidar com crianças e a concepção machista e majoritária que enxerga a atividade como uma aptidão feminina, extensão do cuidado da prole. Buscou-se apresentar elementos requeridos para um estatuto profissional (como postula a sociologia das profissões) e elementos popularmente relacionados à atividade docente, ainda que pulverizados na formação inicial como observado por Gatti (2010) e ao longo da história de vida como propõe Nóvoa (1992).

Em seguida os professores iniciantes foram solicitados a conferir o nível de importância/relevância de uma série de afirmações que fazem menção a critérios de profissionalização da atividade, comprometimento e cumprimento de exigências e competências e ainda acerca da aquisição de saberes e disposições específicas para o trabalho docente (SILVA; ALMEIDA, 2015). A tentativa foi compreender o que os professores inquiridos reproduzem na execução das atividades docentes, sob os aspectos do envolvimento, desenvolvimento e desempenho do trabalho no início da carreira.

Diante de características geralmente atribuídas ao magistério como atividade profissional $^{32}$ (Gráfico 20) a que teve maior concordância para ambos os grupos de professores iniciantes foi a 'exigência do curso de licenciatura'. Isso nos leva a pensar que a atividade é reconhecida como uma carreira universitária igual a qualquer outra, no sentido de que para o seu exercício é obrigatória a formação em nível superior. Mas, como observado anteriormente, o entendimento de um não aumento de prestígio social com a realização da licenciatura é anterior à entrada na universidade.

A posição da ocupação docente na divisão social do trabalho se aproxima de um "seguro desemprego" como alternativa caso outras aspirações ou projetos de emprego e carreira não se realizam. Isso não diminui o compromisso ético com a docência: como veremos adiante, esses professores demonstram engajamento profissional e comprometimento com as finalidades educacionais.

\footnotetext{
32 Três comentários foram feitos sobre a falta de clareza da questão. Um dos respondentes registrou a sua dúvida da seguinte forma: "Não entendi se você quer que indique a realidade ou o que defendo.” [P44]. Como observação metodológica, sugere-se que as questões indiquem explicitamente que a opinião sobre a profissão esteja inscrita ou seja fundamentada nas experiências vividas como professor. Acrescenta-se à observação a diferença entre o objetivo da questão e o declarado pelo respondente, ainda que este se aproxime daquele. Há que se considerar ainda que os professores estão em início de carreira, tateando e adaptando-se às conjunturas, a desenvolver um habitus profissional e uma identidade como docente.
} 


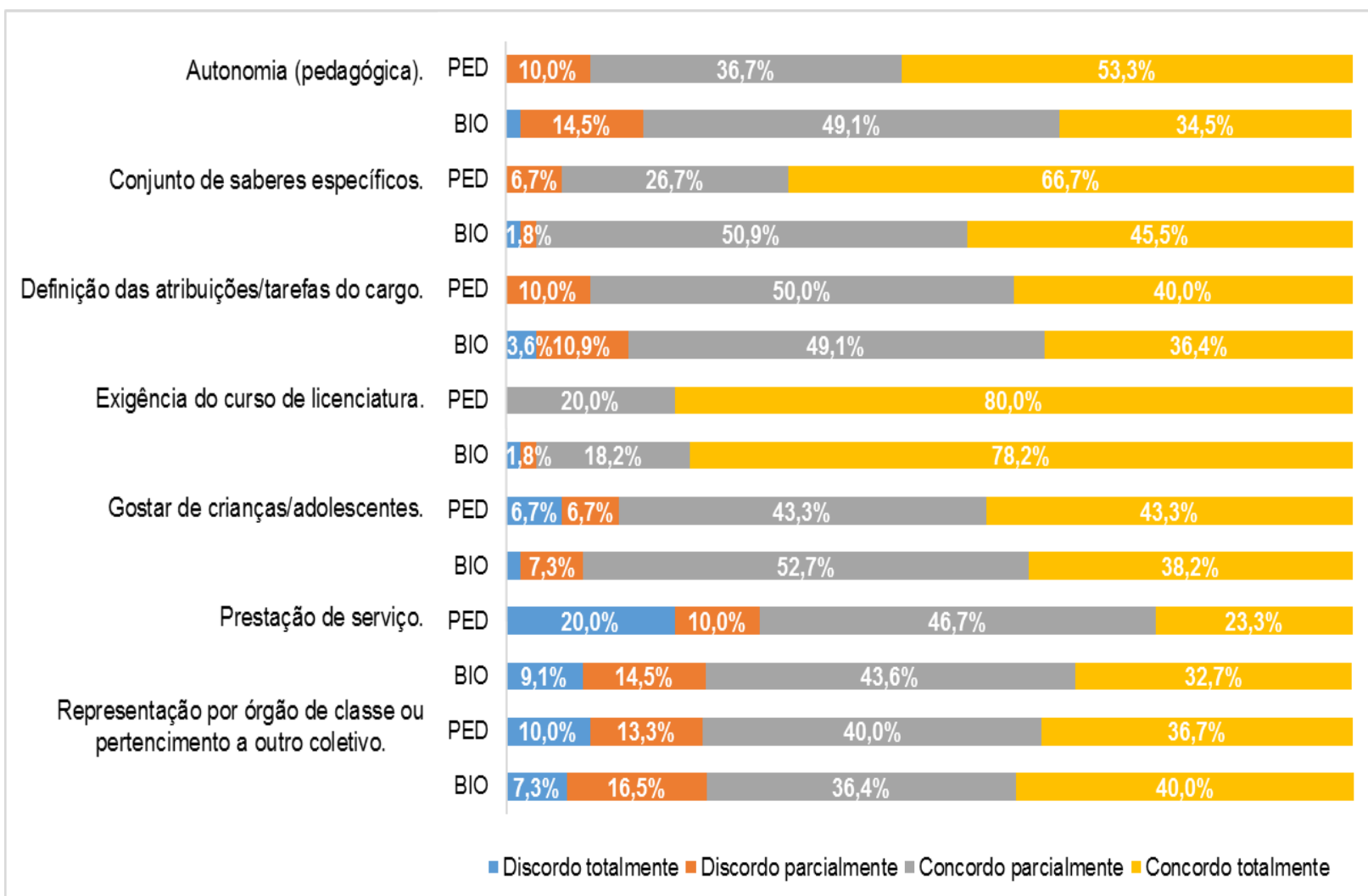

Gráfico 20 - Características do magistério/docência como atividade profissional

Fonte: Elaborado pelo autor.

No entanto, não se pode omitir à expansão da universitarização no país e a uma certa pressão social que tende a exigir a formação em nível superior como o mínimo desejável para entrar no mercado de trabalho e como o ápice da trajetória de escolarização, tendo esta sofrido adaptações e mudanças para conduzir os estudantes até os exames vestibulares e outras formas de acesso à uma graduação.

Um 'conjunto de saberes específicos' aparece em segundo lugar como critério definidor do magistério como profissão, sendo que a concordância total foi maior na Pedagogia. $\mathrm{O}$ item propositalmente não vincula esses saberes à formação inicial ou à aprendizagem em contexto de prática. Buscou-se compreender se os professores iniciantes percebem sua atividade laboral em termos de especificidade dos conhecimentos e/ou competências necessários para uma determinada atividade profissional.

Em teoria, uma profissão é caracterizada pela exclusividade no fornecimento de um "serviço", a satisfação de uma "clientela" e pela separação entre os profissionais e as pessoas não qualificadas (CARR-SAUNDERS; WILSON, 1928 apud DUBAR, 1997, p. 128). Tal entendimento é o mais aceito 
na sociologia das profissões e os autores o vinculam à constituição de uma formação específica e à criação de associações profissionais, que por sua vez atuam como instância que permite aumentar o prestígio do "ofício", definir e controlar as regras de conduta profissional via avaliação e regulação por pares. Como sumariza Dubar (1997, p. 132) "comunidade ética e saber científico, que constituem as duas características específicas de uma "profissão", são inseparáveis da distinção cultural e do fechamento social".

Entretanto, a 'representação por órgão de classe ou pertencimento a outro coletivo' foi o item com a segunda maior rejeição (discordância total e parcial) para os professores que participaram da pesquisa. Nesse quesito duas reflexões se apresentam possíveis: ao retomar os achados da literatura, observamos na fala dos professores em início de carreira um elevado grau de isolamento, abandono ou solidão, quando experimentam, descobrem e aprendem sozinhos parte das funções e dos saberes docentes; a segunda questão trata do desconhecimento ou não reconhecimento de sindicatos e associações, ou ainda a não existência de conselhos profissionais de professores. Os dois argumentos geram a hipótese que professores iniciantes podem ainda não se enxergar como membros de uma profissão, no sentido definido pela sociologia das profissões, e por isso não se interessarem/reconhecerem tais coletivos como espaços possíveis de formação, luta por direitos trabalhistas e estrutura de regulação e valorização da ocupação.

A 'definição das atribuições/tarefas do cargo' aparece em terceiro lugar ao lado de 'gostar de crianças/adolescentes'. Como aponta Nóvoa $(1992,1995)$ há uma inseparabilidade no processo identitário do professor entre os planos pessoal e profissional. Daí o vínculo afetivo com os alunos ter uma alta relevância para caracterizar a atividade e aqueles que nela atuam, tanto quanto a "especialização do serviço". Corrobora-se o observado por Nascimento (2012, p. 31): "Afetividade e compromisso com a aprendizagem se encontram indistintos nas formas como essas professoras falam de suas identidades profissionais".

Importante destacar que os termos 'serviço' e 'cliente' não se referem a relações econômicas, mas de legitimação/validação de ordem simbólica na constituição e reconhecimento profissional (cf. HUGHES apud DUBAR, 1997). E que a aparente facilidade do magistério/docência é descontruída diante da complexidade das tarefas e das exigências que são feitas no cotidiano do trabalho. 
Os licenciados em Pedagogia participantes dessa pesquisa valorizaram mais (maior concordância total e menor discordância) a 'autonomia pedagógica' como critério que defina a atividade profissional do que os licenciados da Biologia. Enquanto que a 'prestação de serviço' foi o item com maior discordância total. Esse item buscou apresentar a educação como direito do cidadão e dever do Estado, e o professor como aquele agente público que viabiliza diretamente o acesso e a oferta dos princípios educacionais. A imprecisão do item possivelmente levou a entendimentos variados e à sua rejeição por uma parte dos respondentes, levanta-se a hipótese de uma leitura mercadológica da educação e a demonstração de um posicionamento crítico dos professores contrário à esta leitura/noção de um serviço desprovido de finalidade intelectual e formação cidadã.

Solicitados a avaliar, em função de suas experiências, a importância de situações pertinentes ao envolvimento do professor com o seu trabalho (Gráfico 21), uma lista de 20 itens foi apresentada. Por envolvimento entende-se as relações entre o conhecimento, engajamento e a prática profissionais com as ações do professor (SILVA; ALMDEIDA, 2015): a demonstração de espírito de cooperação e de parceria, a consciência das responsabilidades individuais e coletivas para com a aprendizagem e o desenvolvimento dos alunos, o sentido ético e social da função, a busca por profissionalização e qualificação, a contextualização e consideração da comunidade escolar como membro do processo educativo e o compromisso em planejar e desenvolver situações de ensino, utilizando-se de procedimentos e suportes variados com a finalidade de apoiar e estimular as aprendizagens dos alunos.

A amplitude, reflete o senso comum e a falta de especificidades dos saberes docentes. A lista abrange questões relativas aos alunos, ao local e a colegas de trabalho, à questões pessoais, à formação contínua e à didática. Dos 20 itens, 17 foram considerados muito importantes com mais de $70 \%$ das respostas, à exceção o item 'saber lidar com o estresse' que para os licenciados em Pedagogia teve $10 \%$ de respostas como pouco importante. 


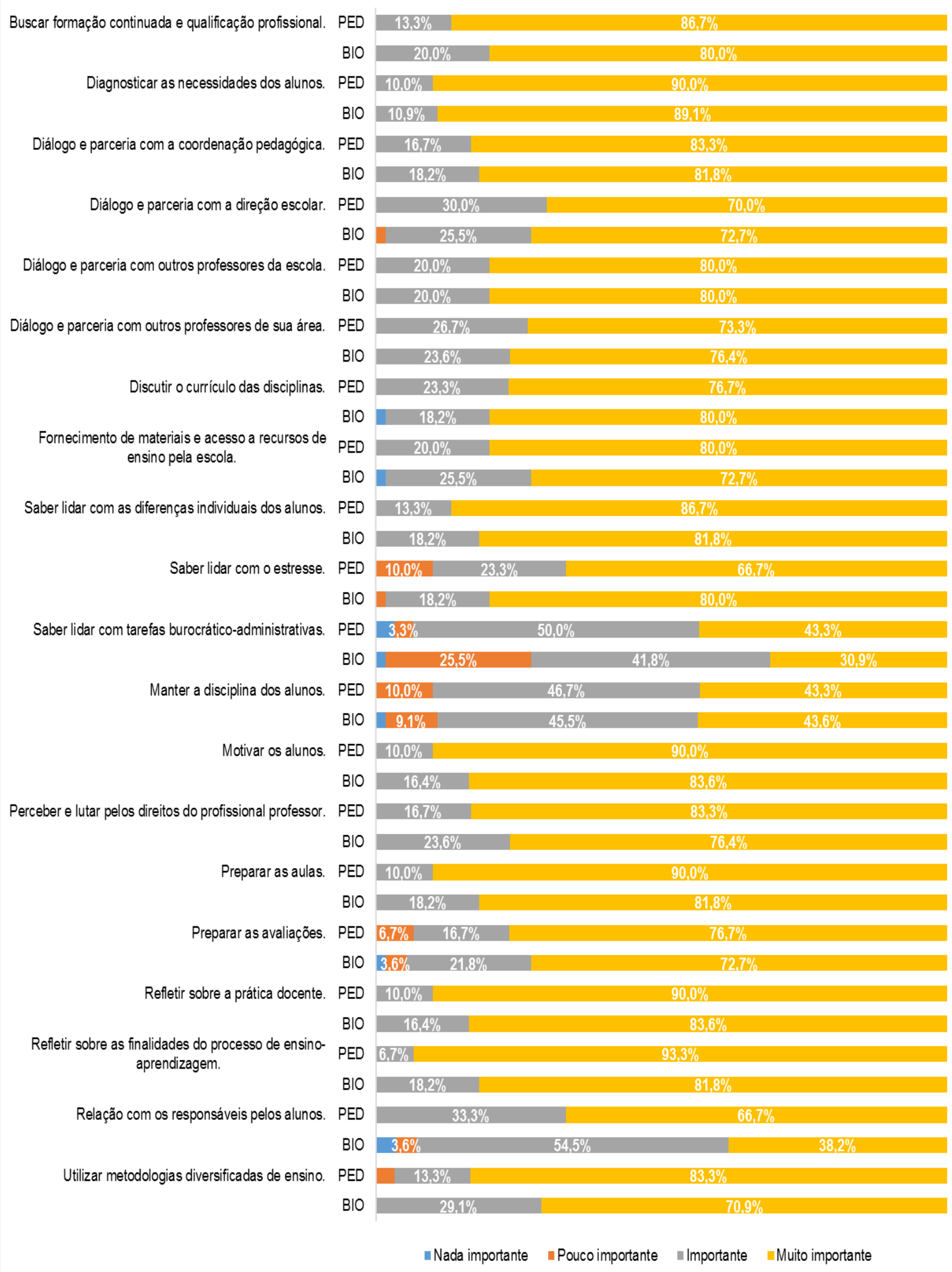

Gráfico 21 - Envolvimento do professor com o trabalho

Fonte: Elaborado pelo autor. 
Ao verificar que, para os professores participantes dessa pesquisa, tudo é importante para o trabalho, há que se ponderar sobre a fluidez do conceito saberes docentes em relação aos conhecimentos profissionais, os quais deveriam ser fundamentados em pesquisas científicas e controlados por um grupo social fechado, de acordo com a sociologia das profissões. Segundo Tardif (2002, p. 33), o saber docente é constituído por "vários saberes provenientes de diferentes fontes. Esses saberes são os saberes disciplinares, curriculares, profissionais (incluindo os das ciências da educação e da pedagogia) e experienciais".

Não se diminui a importância de tais aprendizados que tratam da pluralidade de aspectos ligados à epistemologia da prática e ao processo de constituição identitária do professor. O que se observa nas pesquisas empíricas com professores iniciantes é uma crítica persistente ao excesso de teorias na formação prévia e a reprodução não sistematizada de práticas educativas do cotidiano escolar. O próprio autor alerta que "os saberes dos professores não são uma soma de 'conhecimentos' ou de 'competências' que poderíamos descrever e aprisionar num livro" e que "são amplamente sobredeterminados por questões normativas e até mesmo éticas e políticas" (TARDIF, 2010, n.p.). Portanto, se torna inexato associar os saberes docentes experienciais a saberes profissionais, produzidos e subsidiados cientificamente.

Não se pretende desqualificar as interpretações e as várias formas de agir e se constituir como professor - Nóvoa (1992; 1995; 1999), em coletânea de textos de diversos pesquisadores, aponta a importância de se valorizar a individualidade e as descobertas de si como professor -, mas busca-se, aqui, uma via de objetivação, isto é, uma aproximação com as realidades de trabalho expressa pelos professores ao responderem o questionário, e pontos tangentes com a hipótese de profissionalização. Corrobora-se com a argumentação de Silva (2011) sobre a multiplicidade de saberes necessários à carreira, quando fundamentados por um corpus teórico das ciências de educação, porém:

Se os saberes práticos da docência são produzidos/reproduzidos no âmbito do exercício docente, como mostram as pesquisas, e se o habitus é uma objetivação da interiorização, neste caso, de saberes teóricos aprendidos na universidade, então, a ideia de que a prática docente constitui um habitus professoral ganha mais força. $\mathrm{O}$ que significa que quando os alunos dos cursos de formação de professores estão realizando sua formação inicial nas universidades eles podem apenas desenvolver o habitus estudantil e não o habitus professoral. (SILVA, 2011, p. 354) 
A autora pondera que conhecer o corpus teórico, mas não aplicá-lo ao planejamento e avaliação da prática docente, constitui um habitus estudantil, o qual não tem por princípio e finalidade o "ensino de conteúdos teóricos e metodológicos, por meio de procedimentos didáticos" (SILVA, 2011, 352). Tais argumentos nos levam a duas perguntas: Os cursos de formação de professores exercitam as competências práticas do ser professor? Os professores utilizam a fundamentação teórica na atuação e a reflexão sobre sua prática? E nos leva de volta às perguntas de Cunha (1999, p. 129):

E o professor? Que forças político-sociais estão determinando seu desempenho? O que dele se espera? Como pensar sua formação e sua profissionalidade? Que competências básicas deve ter? É possível e importante defini-las? O que é ser profissional, perante esse quadro? É possível a profissionalização? Que profissionalização? Para quê? Para quem?

Um dos riscos da supervalorização de aspectos práticos é diminuir a importância da formação e fundamentação teórico-científica e, assim, reduzir o estatuto da atividade pedagógica a um ofício, rompendo, portanto, com os princípios que permitem enxergar e reconhecer o trabalho docente como categoria profissional. Atribui-se a pertinência e persistência da crítica dos professores em início de carreira sobre: o excesso de teorizações na formação inicial, os sentimentos de abandono e despreparo apontados quando em exercício docente, o distanciamento entre teoria e prática e a falta de estímulos para que se utilize os referenciais teóricos na discussão e elaboração de estratégias para as situações práticas dos contextos de trabalho.

Tal distância é medida em função da falta de diálogos formativo-reflexivos mais intensos e horizontais entre universidades e escolas e em função da noção equivocada de que às universidades cabe conferir a credencial para atuação profissional e às escolas cabe mostrar como executar as tarefas e atividades do professor, não raro da forma mais traumática e difícil. A desigualdade e hierarquização entre os aspectos formativos e constitutivos da identidade profissional do professor (saberes, conhecimentos e disposições) desenvolvidos entre a universidade e a escola também são pontos que comprometem o entendimento de um desenvolvimento profissional. 
Os outros três itens relativos ao envolvimento com o trabalho, 'relação com os responsáveis pelos alunos', 'manter a disciplina dos alunos' e 'saber lidar com as tarefas burocrático-administrativas', foram, em geral, classificados como importantes e tiveram poucas respostas como pouco ou nada importante. O relacionamento com os responsáveis foi considerado muito mais importante pelos professores formados em Pedagogia do que aqueles formados em Biologia. Formula-se a hipótese de o professor de educação infantil e séries iniciais do ensino fundamental conviver muito mais tempo com os mesmos alunos ao longo de uma semana letiva do que os professores especialistas (Biologia) que oferecem apenas uma disciplina e ficam menos tempo com os mesmos alunos. Esse convívio mais intenso e a menor quantidade total de alunos dos professores generalistas (Pedagogia) leva a maiores chances de contato com os responsáveis desses alunos e, assim, a maior importância que esses professores dão em conhecê-los.

A questão da disciplina teve praticamente a mesma percentagem de respostas como pouco importante (cerca de 10\%) e o restante se dividiu igualmente entre importante ou muito importante, isso sugere que a disciplinarização do comportamento perdeu a liderança na lista de dificuldades ou problemas para o professor iniciante. Veenman (1984) aponta a disciplina em sala de aula como a preocupação mais frequente numa revisão sobre o tema e Moura (1998) observou como uma das dificuldades mais comuns dos professores iniciantes em sua pesquisa. Por fim, as tarefas burocrático-administrativas aparecem com os menores percentuais de importância para o envolvimento do professor com o trabalho, a isso sugere-se a predominância de aspectos eminentemente pedagógicos sobre as atividades que não exijam contato com os alunos.

De forma análoga ao item educação como prestação de serviço, faz-se necessário reconhecer alguma imprecisão e a possível aversão à expressão burocrático-administrativas. Com o item, esperava-se indicar o conjunto de procedimentos e exigências tais como o preenchimento de diários de classe e outros documentos intra ou extraescolares, tarefas relativas à gestão e à publicidade do trabalho realizado e quaisquer outras tarefas que não tenham interação com os estudantes. Uma das respondentes registra, inclusive, 
reclamação sobre a realização de tais tarefas não vinculadas a propósitos didáticos: "obrigação de fazer para fins de registro e publicidade" [P44].

Esses três itens 'relação com os responsáveis pelos alunos', 'manter a disciplina dos alunos' e 'saber lidar com as tarefas burocrático-administrativas' aludem ao acúmulo de papéis e funções submetidas aos professores, em detrimento das funções pedagógicas e didáticas da profissão, que por sua vez estão ligados à precarização do trabalho docente.

Sobre os argumentos comumente apontados para a motivação do professor no desenvolvimento do seu trabalho (Gráfico 22), dos sete itens apresentados cinco foram considerados muito importantes ou importantes e com menos de $4 \%$ de respostas contrárias (pouco ou nada importante) cada. São eles: 'capacitação através da formação continuada', 'infraestrutura e materiais de apoio na escola', 'reconhecimento da comunidade escolar', 'salário e plano de carreira' e 'troca de experiências com os colegas de trabalho'.

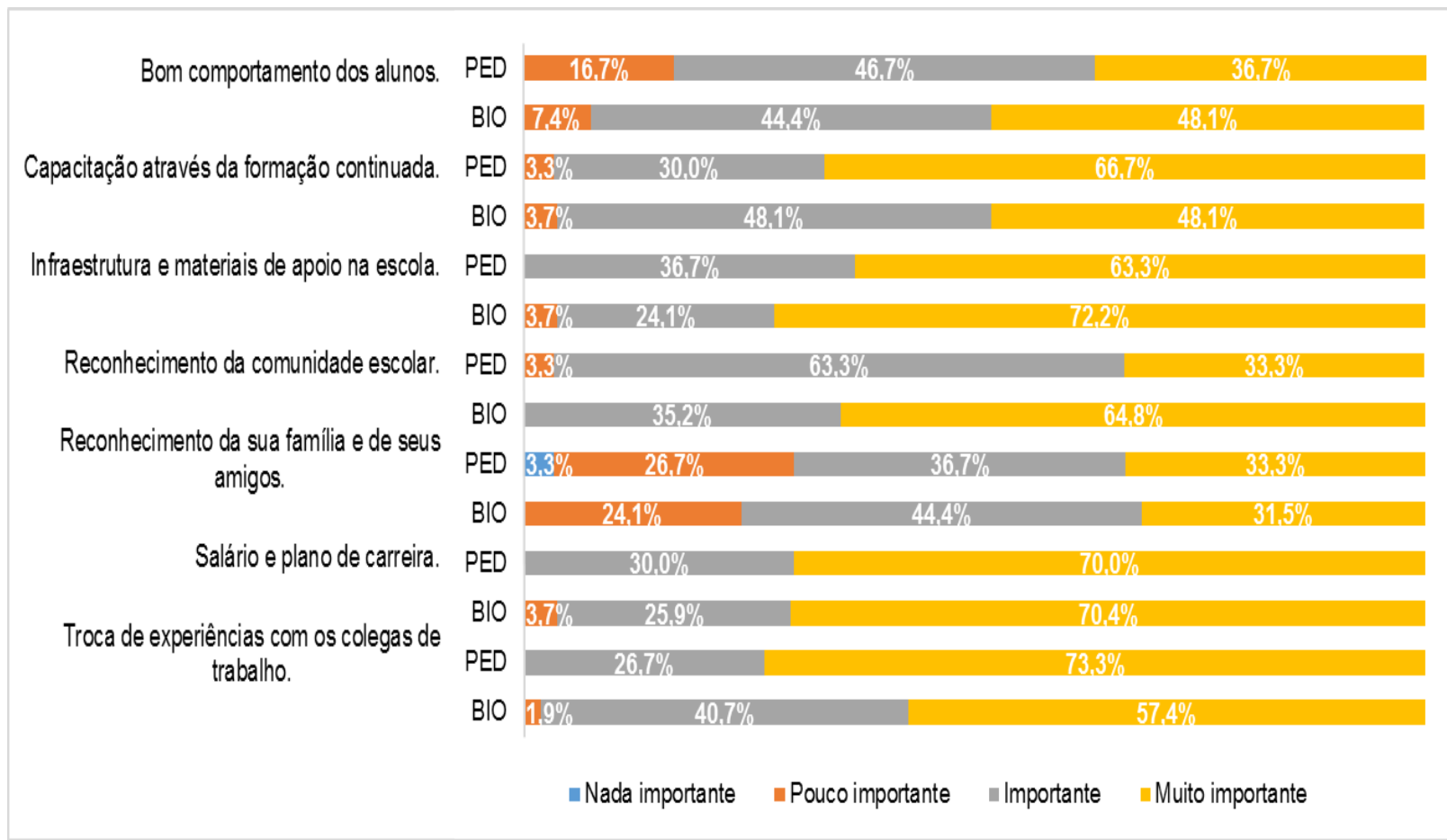

\section{Gráfico 22 - Motivações do professor para o desenvolvimento do trabalho}

Fonte: Elaborado pelo autor.

O item de motivação para o trabalho com mais respostas muito importante para os licenciados em Pedagogia foram as trocas de experiências e para os licenciados em Biologia foi a 'infraestrutura e materiais de apoio na escola'. 
Embora a diferença percentual desse indicador (muito importante) seja ínfima, levantamos como hipótese que a socialização no trabalho seja maior entre os professores generalistas e a coordenação pedagógica do que para os professores especialistas.

Em segundo lugar para ambos os grupos de licenciados, o salário e a carreira aparecem como fatores de motivação para o seu desenvolvimento profissional. Esse dado indica a consciência da precarização dos rendimentos no magistério quando comparados com o de outras carreiras universitárias como debatido anteriormente.

O reconhecimento da própria família do professor e de seus amigos recebeu a maior quantidade de respostas como item pouco ou nada importante para o desenvolvimento do trabalho, seguido pelo 'bom comportamento dos alunos'. Embora tenha sido observada alguma não importância para esses dois itens, a ampla maioria dos participantes acredita que tenham alguma influência importante ou muito importante para o trabalho.

Acerca do desempenho do professor (Gráfico 23), como fator associado a uma maior permanência na profissão, foi solicitado aos respondentes que ponderassem a influência ou relevância de algumas variáveis do trabalho docente. Um dos respondentes comentou que a questão deixava em aberto à dupla interpretação sobre o que seria importante idealmente ou como foi a influência dessas variáveis em suas experiências de trabalho. De fato, a pergunta não vincula as variáveis listadas com o trabalho e o nível de desempenho de acordo com as vivências no início da carreira. Ainda assim, os dados são apresentados reconhecendo os limites da abordagem metodológica adotada.

Nesse caso, variáveis para o desempenho do trabalho do professor são o acolhimento institucional, o ambiente escolar, os alunos, os responsáveis, o comprometimento pessoal, os investimentos da administração e o grau de exigência da gestão, ou seja, características dos demais agentes ou da estrutura do campo que se inter-relacionam e podem influenciar nas estratégias e posições que os professores assumem. A variável com maior percentual muito relevante foi 'investimentos da administração (pública ou privada) na rede de ensino' ${ }^{33}$, embora

33 Um erro na redação desse item pode ter gerado confusão, considerando a dependência administrativa do local de trabalho do respondente. A versão que foi apresentada aos professores 
todos os sete itens tenham sido considerados relevantes, ou muito relevantes. O 'acolhimento e orientação da equipe pedagógica e docente', 'ambiente escolar: alunado, funcionários e corpo docente' e 'seu investimento/ comprometimento pessoal' não receberam opiniões contrárias à sua importância.

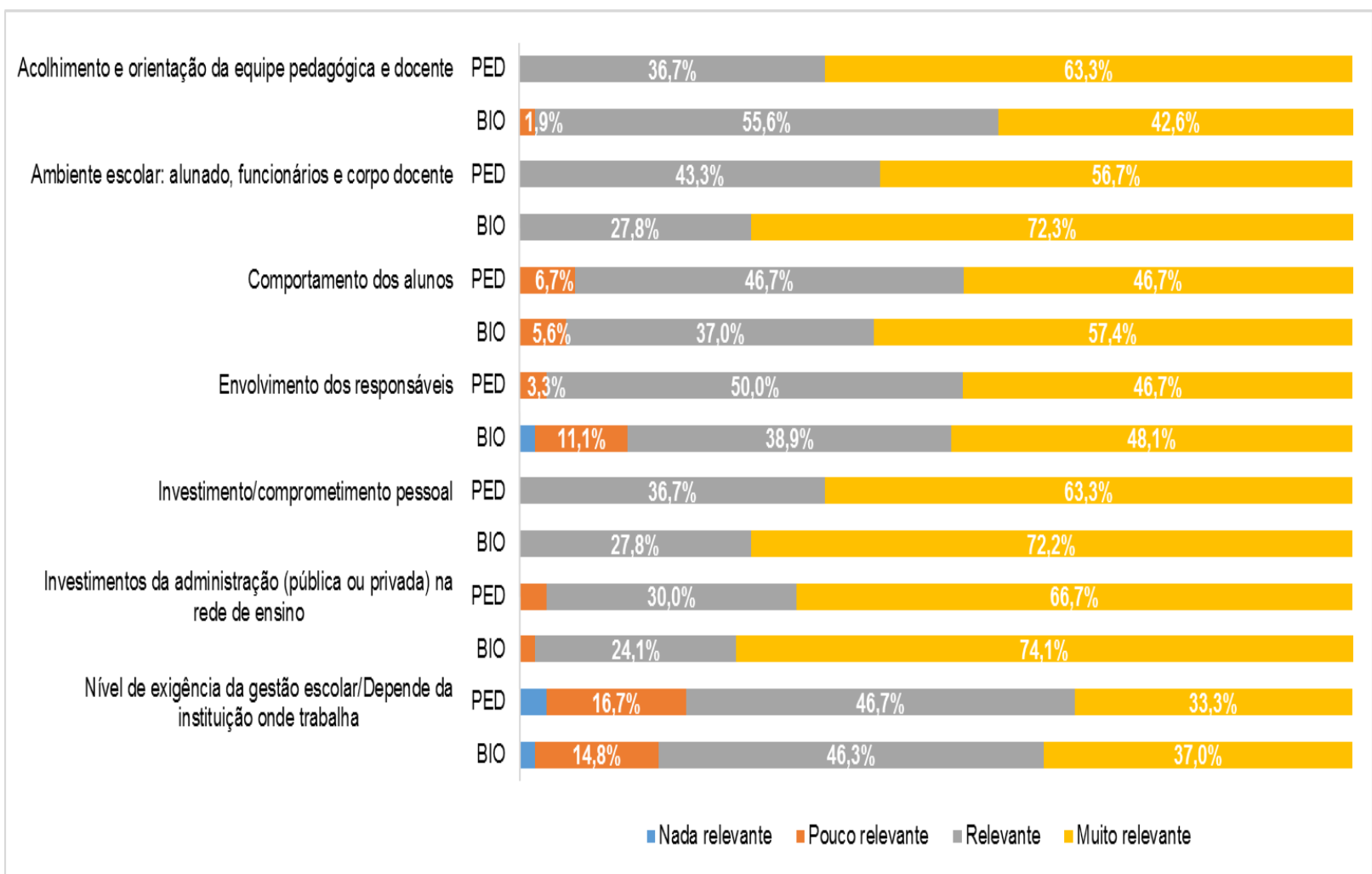

\section{Gráfico 23 - Fatores de influência sobre o desempenho do professor}

Fonte: Elaborado pelo autor.

A variável de investimentos foi valorizada tanto pelos professores que trabalham em escolas particulares como em escolas públicas e de forma muito similar pelos licenciados da Pedagogia e Biologia. Contudo, as redes de ensino particulares não dependem direta e exclusivamente de investimentos do governo como as redes de ensino públicas. A possível ambiguidade também comporta a hipótese de que os respondentes compreenderam 'investimentos do governo' em educação como política pública, elaboração de leis, portarias e realização de avaliações, logo, influenciando todos os estabelecimentos e professores quais sejam seus vínculos de trabalho.

participantes da pesquisa foi 'investimentos do governo (da administração privada ou pública)'. Embora o erro tenha sido identificado logo após o questionário ter recebido as primeiras respostas, decidiu-se por não alterá-lo durante a etapa de campo. 
As variáveis comprometimento pessoal e ambiente escolar foram as únicas que não tiveram respostas que as desvinculassem do desempenho do professor. Isso reitera o entendimento desses professores iniciantes da inter-relação entre a identidade pessoal e a profissional, fundamentada nos princípios éticos da atividade e no estabelecimento de um bom convívio pessoal e mesmo vínculos afetivos com as demais pessoas envolvidas com seu trabalho, sejam alunos, funcionários ou os colegas professores.

O acolhimento institucional, embora presente foi observado de forma incipiente e pouco estruturada, apenas um professor afirmou participar de um programa de iniciação docente sistematizado. Os demais vivenciaram experiências pontuais e não voltadas para a reflexão sobre a prática, sendo raros os encontros coletivos-colaborativos. Entre os professores formados na Pedagogia a variável teve mais respostas muito relevantes do que para os professores formados na Biologia, 1,9\% destes, por sua vez, chegam a indicar que o item é pouco relevante para o desempenho profissional.

Como observado por Corrêa (2015) e Papi (2012) há uma fragilidade do trabalho coletivo-colaborativo, especialmente na inserção dos professores iniciantes. Papi (2012, n.p.) pondera que "o componente afetivo se sobressaiu em detrimento do desenvolvimento de outras ações de caráter mais propositivo que pudessem facilitar o processo de melhoria da prática pedagógica" no chamado dia de organização do trabalho pedagógico, ou reuniões pedagógicas, que é marcado por mensagens motivacionais e avisos administrativos.

Os três itens restantes foram considerados, em geral, relevantes, porém, com algumas respostas contrárias, do tipo pouco relevante ou nada relevante para o desempenho do professor. Como é o caso de 'envolvimento dos responsáveis' e o 'nível de exigência da gestão escolar/depende da instituição onde trabalha'.

Ao recuperar o posicionamento dos respondentes sobre a importância da relação com os responsáveis para o seu envolvimento com o trabalho (Gráfico 21) e comparar com a mesma variável para o desempenho do professor (Gráfico 23) podemos sugerir que os licenciados em Biologia têm menor proximidade com os responsáveis pelos alunos e uma pequena parcela destes iniciantes acredita que os pais não influenciam em quase nada seu trabalho. Enfatiza-se o número restrito da amostra e a impossibilidade de extrapolar os achados, ainda assim, fica como hipótese o menor contato dos professores especialistas com os responsáveis pelos 
alunos, do que o estabelecido pelos professores generalistas. Disso pode decorrer desde o desinteresse dos estudantes pela escola, como o surgimento de problemas de indisciplina e dificuldades de aprendizagem, ou mesmo, aversão à algumas disciplinas do currículo escolar.

Sobre o nível de exigência da gestão escolar, esta foi a variável que apresentou os maiores percentuais contrários dentre as variáveis listadas que podem influenciar o trabalho do professor. Embora cerca de $46 \%$ dos respondentes considerem relevante e $37 \%$ muito relevante, cerca de $15 \%$ também apontou que ele é pouco ou nada relevante.

As relações estabelecidas em cada unidade escolar entre professores e equipe pedagógica, liderança da direção, entre outros fatores, tendem a ser muito influentes sobre as potencialidades do trabalho ou do isolamento do professor, uma variável igualmente sujeita à pluralidade de contextos de trabalho onde essa influência pode ser positiva ou negativa.

Alguns elementos referentes aos saberes docentes (TARDIF, 2002; 2010), ao habitus professoral (SILVA, 2011; TOWNSEND, TOMAZZETI, 2007) e do capital pedagógico (LELIS, 1996), em sua pluralidade e complexidade, oriundos de trajetórias de experiências variadas e acúmulo de disposições e valores, foram colocados em avaliação de importância relativa como aprendizados profissionais e indicadores de permanência e continuidade do trabalho como professor (Gráfico 24).

O item 'aprendizado com as dificuldades do cotidiano' foi o que recebeu menos votos contrários (menos de $4 \%$ achou pouco ou nada importante) e vai ao encontro do que Huberman (1992) descreve como descoberta e sobrevivência: um conjunto de estratégias de adaptação e incorporação de disposições específicas do trabalho como professor e suas relações com os alunos, colegas professores e a escola ou sistemas de ensino.

$\mathrm{O}$ item mais valorizado pelos professores iniciantes licenciados em Pedagogia foi a 'criatividade para elaborar materiais e estratégias de ensinoaprendizagem' com 56,7\% de respostas muito importante e 36,7\% importante. Já entre os professores da Biologia, 'autonomia para planejar aulas, atividades e avaliações' recebeu $61,1 \%$ de respostas muito importante e $25,9 \%$ importante. O item 'dicas e sugestões aprendidos com os colegas de trabalho' aparece em segundo lugar para ambos os professores. 


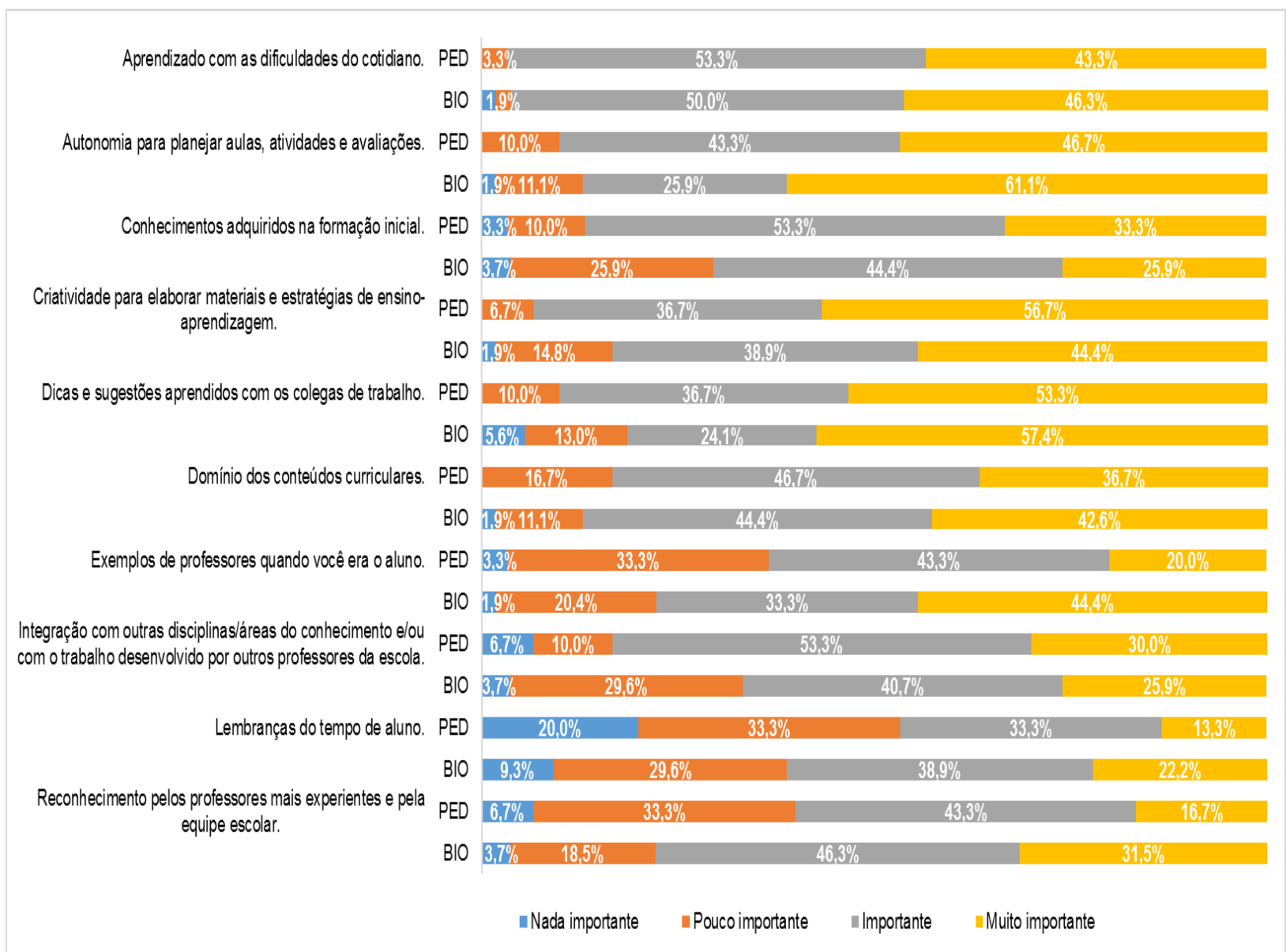

Gráfico 24 - Aprendizados e crenças associados ao trabalho do professor nos primeiros anos da carreira

Fonte: Elaborado pelo autor.

O item menos relacionado como saber necessário para permanência e continuidade do trabalho como professor foi 'lembranças do tempo de aluno', o qual obteve a maior quantidade de respostas nada importante entre as dez variáveis, sendo 20,0\% na Pedagogia e 9,3\% na Biologia, valores percentuais bem superiores à rejeição dos demais itens. A literatura indica com grande regularidade que parte das tomadas de decisão se fundamenta com exemplos mobilizados pelos professores a partir de suas vivências como alunos. Outro item que destoa das demais pesquisas consultadas foi 'exemplos de professores quando você era o aluno', embora a maioria dos respondentes de ambas as licenciaturas reconheça sua importância Todas as demais variáveis apresentadas, alusivas à aprendizados e saberes que constituem a profissionalidade docente tiveram respostas majoritariamente relacionadas de forma positiva com a prática do professor nos primeiros anos de carreira. 
As críticas dos professores participantes dessa pesquisa, reunidas nas defasagens da formação prévia, na descontinuidade e isolamento de um processo formativo ao longo da vida profissional e nas dificuldades do início da carreira são mais urgentes do que o grau de profissionalismo no sentido corporativista para definição de um grupo profissional. O que não significa que o estatuto profissional não deva ser debatido em favor de uma outra configuração em que os professores interajam mais direta e igualitariamente sobre sua formação, atuação e regulação.

As representações acerca do choque de realidade (entre expectativas e consciência dos limites) e da necessidade de valorização do trabalho e dos saberes docentes que emergem da prática se reportam à especificidade do ensinoaprendizagem no sentido de constituir uma profissionalidade docente, um comprometimento ético com a as finalidades político-sociais da ação didáticopedagógica. $\mathrm{O}$ entendimento de um desenvolvimento pessoal e profissional que perpasse o domínio e a utilização de um conjunto de conhecimentos específicos deve guiar-se pelo planejamento e reflexão sobre a didática.

A proposta de investigar e "comparar" dois cursos de formação de professores como a Pedagogia e a Biologia tinha como princípio identificar as homologias sobre a constituição da identidade profissional. Foi possível ver como a sonegação de um enfoque formativo na instrumentalização do professor para lidar com o processo de ensino-aprendizagem se reflete na fragilidade de sua percepção como especialista em ensino. Isso nos remete às questões levantadas por Candau e Lelis (2005, p. 70-71), há mais de trinta anos : “'Como é trabalhada a relação teoria-prática na dinâmica do curso [de formação do educador]? Que visão de competência profissional é transmitida pelo curso? A fundamentação teórica está voltada para a prática a ser exercida pelo educador?”. Os questionamentos, direcionados a formadores de professores, não são novos, mas se fazem cada vez mais necessários.

A ampliação da noção e importância das ciências da Educação deve ser relativizada em função do aligeiramento da formação prévia e a dispersão de conhecimentos em detrimento ao estudo e desenvolvimento das didáticas, como núcleo científico e articulador da formação e atuação profissional específica do professor. A hipótese apresenta suporte na teoria da sociologia das profissões e no olhar sobre a empiria produzido por essa investigação. 


\section{5 \\ Considerações finais}

A abordagem exploratório-descritiva de representações sobre a atividade docente tende para a hipótese de uma atividade em vias de profissionalização, o que não deve ser visto sob qualquer tentativa de inferiorizar a profissão professor perante as demais. Cada uma tem sua importância e os desafios para sua constituição e desenvolvimento, por conseguinte de seus membros ingressantes e experientes. O não reconhecimento de instâncias coletivas de regulação da formação e atuação profissional, a pluralidade e a indefinição dos saberes docentes e os sentimentos de insegurança (sobre a atividade pedagógica, domínio de conteúdos e metodologias) e despreparo (evidenciado pelas críticas sobre a formação inicial distante de aspectos práticos e contextuais do trabalho docente) são alguns exemplos observados que apontam a procedência de tal hipótese.

A evidenciação de aprendizados e descobertas de um ethos profissional (pela incorporação de um habitus professoral e o acúmulo de um capital pedagógico) que se intensifica e complexifica pela imersão na cultura escolar e nas relações estabelecidas no campo educacional, nos levam a pensar a carreira docente como uma atividade eminentemente praxiológica. No entanto, magistério/docência como uma ocupação profissional que se reconstrói e se adapta às finalidades educacionais a partir da avaliação e reflexão sobre a prática, só é possível pelo domínio de um conjunto de teorias e conhecimentos científicos específicos.

A presente pesquisa pôde identificar a relação entre as insuficiências da formação prévia nos cursos de licenciatura e os sentimentos de dificuldade e insegurança dos professores iniciantes relativos à especificidade da prática profissional do professor que é o ensino. A entrada no universo do trabalho possui desafios próprios da mudança de perspectiva do estudante que se torna professor, mas também está associada diretamente à pouca ênfase em aspectos ligados ao como fazer e ao como ensinar, isto é, uma crítica à importância da didática nos cursos de licenciatura. 
Ao enumerar achados da literatura sobre a formação docente (motivações para acesso e permanência na profissão, desenvolvimento ou abandono da mesma) e discutir o que tem se convencionado a chamar de saberes docentes (partindo do senso comum à fluidez e fragilidade do conceito), foi possível medir com o uso de escalas o comprometimento e a importância dada pelos professores, bem como identificar as possibilidades e os limites, daquilo que caracteriza o trabalho docente. Do ponto de vista desses professores em início de carreira, a não valorização dos aspectos didáticos-pedagógicos na formação inicial está diretamente relacionada com a falta de clareza e a precarização de sua prática profissional.

Elementos que indicam um código ético e deontológico para a atividade docente, somados à iniciação conferida numa formação prévia específica, fundamentada por um campo do saber próprio (ainda que ciências da Educação configure um campo múltiplo), afastam a interpretação de uma atividade do tipo ofício. A aparente facilidade do trabalho do professor, frente à diversidade de teorias que lhe servem ao planejamento e reflexão sobre a prática pedagógica são características da complexidade do trabalho docente. Tais características o diferenciam de outras carreiras universitárias, para além de uma comparação superficial e não construtiva com outras ocupações, ou profissões, se nos é exigido reconhecimento à vaidade com que edificam seu poder de fechamento e exclusividade do serviço, como define a sociologia das profissões.

A comparação com outras profissões não fornece parâmetros adequados ao trabalho docente, de modo a contribuir para a melhoraria da formação inicial ou pela inserção do profissional do ensino, por isso não deveriam ser o foco de análises. Há grande convergência entre os pesquisadores e os professores iniciantes acerca da importância do desenvolvimento contínuo (formativo e identitário) das características e competências requeridas para o exercício do magistério/docência. Para além das categorias teóricas, o estudo das dificuldades, descobertas e experiências de sucesso e pioneirismo dos professores em início de carreira, visa contribuir com a melhoria dos processos formativos prévios, nos cursos de licenciatura, e aqueles subsequentes, incluindo-se a necessidade de formação coletivo-colaborativa que busca soluções às demandas educacionais locais pelos grupos de pares, em função da comunidade escolar e do conjunto de alunos que atende. 
As tentativas de valorização dos saberes docentes sobre o se tornar professor não tem encontrado respostas às dificuldades da prática pedagógica devido à carência de elementos que suportem o núcleo da profissão. Os saberes profissionais, são aqueles oferecidos e discutidos na formação inicial e as didáticas fornecem o instrumental de trabalho necessário para elaborar e adaptar as estratégias de aprendizagem às necessidades dos alunos que serão atendidos.

A análise das representações sobre os primeiros anos de carreira docente pode fomentar ajustes nos programas de formação inicial e em serviço, a fim de sistematizar a aprendizagem dos saberes docentes e, assim, evitar a repetição de fórmulas e tentativas individuais e isoladas, ainda que verdadeiramente comprometidas com o desenvolvimento dos alunos. A proposição de programas de incentivo à docência, acompanhamento e acolhimento dos iniciantes aparece pontual e incipiente no Brasil, diferente do que já ocorre em países que superaram a identificação das dificuldades e buscam outros percursos formativos com e para os professores, pautados por valorização de saberes práticos e reflexões in situ, na premissa do professor-pesquisador e valendo-se das teorias educacionais.

As instituições de ensino superior têm se omitido do acompanhamento dos seus egressos no mercado de trabalho e, assim, deixam de incluir críticas e demandas que venham a subsidiar outra estrutura curricular nos cursos de formação de professores, tais como: a ampliação do tempo de estágio supervisionado; a inclusão de discussões sobre as múltiplas realidades de trabalho com elementos propositivos e reflexivos dos fundamentos teóricos; o debate sobre os conteúdos e a estrutura curricular escolar; a abordagem prática da seleção de conteúdos, transposição didática e utilização de tecnologias de informação e comunicação, integrados aos objetivos educacionais; o planejamento de avaliações e o uso dos resultados de avaliações internas e externas como mecanismos para aprimoramento do processo de ensino-aprendizagem.

A própria pressuposição de que os resultados de aprendizagem por meio de expedientes de avaliação escolar possam atestar a "qualidade de ensino" ministrado não faz justiça aos elementos constituintes e indissociáveis do ensino escolar, ainda que se possa localizar no professor seu agente precípuo. (SILVA; ALMEIDA, 2015, p. 17)

Nesse sentido, as IES deveriam se aproximar das escolas valorizando os contextos de ação docente na educação básica como espaços formativos, como 
sugerido por Moura (1998), Pimenta (2006), Gatti (2012b), Lüdke e Boing (2012) e André (2013). A valorização e o reconhecimento social dos professores também se fazem necessários, por parte dos gestores e administradores de sistemas e redes de ensino, como aponta Gatti (2012a) e pelos próprios futuros professores, professores formadores e na estrutura organizacional das escolas como apontam Nóvoa (1995), Schön (1995) e Neto, Sarti e Benites (2012). O que se sugere ainda é a inclusão e o estímulo da reflexão sobre o cotidiano de trabalho do professor no âmbito da formação prévia ou inicial de novos professores e no desenvolvimento profissional dos egressos das licenciaturas já inseridos no mercado de trabalho. Assim, espera-se que os processos formativos discutam os problemas reais e viabilizem soluções possíveis para diminuir o choque de realidade, contribuir com formas de diminuir o abandono da profissão, os sentimentos de desamparo e despreparo e, por conseguinte, promover a qualidade do ensino oferecido aos alunos da educação básica.

\begin{abstract}
É importante que foquemos o olhar sociológico no trabalho real e não no prescrito, levando sempre em conta que o trabalho docente está passando por transformações. Ainda que as estruturas organizacionais das escolas e os currículos permaneçam reféns da forma escolar, a entrada constante de novas gerações de alunos questiona a racionalidade da atual preparação dos professores para o trabalho, mesmo daquele que tem dado certo até aqui. O professor que busca realizar um bom trabalho necessita superar-se e reinventar-se constantemente. $\mathrm{Na}$ realidade, o professor vive em estado de construção permanente da profissionalidade. (LÜDKE; BOING, 2012, p. 443)
\end{abstract}

A persistência dos problemas e dificuldades é questão posta na literatura, mesmo considerados os determinantes sócio-históricos das diversas pesquisas realizadas sobre o início da docência no Brasil e no mundo. Corrobora-se com Papi (2011b, n.p.) acerca das condições objetivas de trabalho dos professores e que suas iniciativas podem "ser entendidas tanto como formas implícitas de resistência/questionamento ao instituído, quanto como formas de ação que revelam necessidades em seu processo de desenvolvimento profissional.”. E com Damiani (2008, p. 224-5) sobre o "desenvolvimento de atividades de maneira colegiada" e a criação de um "ambiente de aprendizagens acadêmicas e sociais", que venham proporcionar maior satisfação profissional e o resgate de valores como o compartilhamento e a solidariedade. 
A responsabilidade social e política sobre o papel do professor, as finalidades educacionais e a oferta de uma escola pública de qualidade também constituem elementos para a superação das dificuldades e problemas. Assim como a busca por maiores investimentos e a melhor adequação e destinação dos recursos para a formação dos profissionais da educação e oferecimento de infraestrutura suficiente para realização das atividades de ensino-aprendizagem.

O debate sobre os saberes docentes, a incorporação de um habitus professoral e a constituição e mobilização de um capital pedagógico não devem ser entendidas como possibilidades de discussão teórica, mas aplicadas em processos formativos, identitários e reflexivos que valorizem a profissionalidade no desenvolvimento pessoal e profissional do professor, com ênfase na sua especificidade que é o desenvolvimento de atividades didático-pedagógicas. 


\section{6 Referências bibliográficas}

ALMEIDA, António José. Contributos da Sociologia para a compreensão dos processos de profissionalização. Medi@ ções [Revista OnLine], Setúbal/Portugal, v. 1, n. 2, p. 115-127, 2010. Disponível em: <http://mediacoes.ese.ips.pt/index. php/mediacoesonline/article/view/28/pdf_13>. Acesso em: 29/11/2014.

ALVES, Cristovam da Silva; ANDRÉ, Marli Eliza Dalmazo Afonso de. A constituição da profissionalidade docente: os efeitos do campo de tensão do contexto escolar sobre os professores. Trabalho apresentado na $36^{\mathrm{a}}$ Reunião Anual da ANPEd. Goiânia, 2013. Disponível em: <http://36reuniao.anped.org.br/pdfs_ trabalhos_aprovados/gt08_trabalhos_pdfs/ gt08_2640_texto.pdf $>$. Acesso em: 16/09/2014.

ALVES, Mariana Gaio; AZEVEDO, Nair Rios; GONÇALVES, Teresa N. R. Satisfação e situação profissional: um estudo com professores nos primeiros anos de carreira. Educação e Pesquisa, São Paulo, vol. 40, n.2, p. 365-382, 2014.

ANDRÉ, Marli Eliza Dalmazo Afonso de. (Org.). Formação de professores no Brasil (1990-1998). Brasília: MEC/Inep/Comped, 2002.

Políticas de apoio aos docentes em estados e municípios brasileiros: dilemas na formação de professores. Educar em Revista, Curitiba, n. 50, p. 3549, 2013.

ANDRÉ, Marli; SIMÕES, Regina H. S.; CARVALHO, Janete M.; BRZEZINSKI, Iria. Estado da Arte da Formação de Professores no Brasil. Educação \& Sociedade, Campinas, v. 20, n. 68, p. 301-309, 1999.

BABBIE, Earl. Métodos de pesquisas de Survey. $2^{\mathrm{a}}$ reimpressão. Belo Horizonte: Ed. UFMG, 2003.

BALL, S.J. "Reformar escolas/reformar professores e os terrores da performatividade". Revista Portuguesa de Educação, Braga/Portugal, v. 15, n. 2, p. 3-23, 2002.

BARBOSA, Maria Lígia de Oliveira. As profissões no Brasil e sua sociologia. Dados, Rio de Janeiro, v. 46, n. 3, p. 593-607, 2003.

BARROSO, João. O estudo da autonomia da escola: da autonomia decretada à autonomia construída. In: BARROSO, João. (Org.). O estudo da escola. Porto/Portugal: Porto Ed., 1996. p. 167-189.

BOURDIEU, Pierre. Coisas ditas. $1^{a}$ reimpressão. São Paulo: Brasiliense, 2004.

Escritos de educação. 15ª ed. Petrópolis: Vozes, 2014.

Brasil, 1989.

O poder simbólico. Lisboa/Portugal: Difel, Rio de Janeiro: Bertrand

Razões práticas: sobre a teoria da ação. $9^{a}$ ed. Campinas: Papirus, 2008. 
BOURDIEU, Pierre; PASSERON, Jean-Claude. A reprodução: elementos para uma teoria do sistema de ensino. $3^{\mathrm{a}}$ ed. Rio de Janeiro: Francisco Alves, 1992.

BRANDALISE, Mary Ângela T. Avaliação dos cursos de graduação na perspectiva dos egressos: um indicador de avaliação institucional. Trabalho apresentado na IX Reunião Anual da ANPEd Sul. Caxias do Sul, 2012. Disponível em: <http://www.ucs.br/etc/conferencias/index.php/anpedsul/ 9anpedsul/paper/download/2480/741>. Acesso em: 12/08/2015.

BRANDÃO, Zaia. Pesquisa em Educação: Conversas com pós-graduandos. Rio de Janeiro: Ed. PUC-Rio; São Paulo: Loyola, 2002.

Operando com conceitos: com e para além de Bourdieu. Educação e Pesquisa, São Paulo, v. 36, n. 1, p. 227-241, 2010.

BRASIL. Lei $\mathrm{n}^{\circ}$ 9.394, de 20 de dezembro de 1996. Estabelece as diretrizes e bases da educação nacional. Disponível em <http://www.planalto.gov.br/ccivil_03 /Leis/L9394.htm>. Acesso em:25/11/2014.

Lei $\mathrm{n}^{\mathrm{o}}$ 10.861, de 14 de abril de 2004. Institui o Sistema Nacional de Avaliação da Educação Superior - SINAES e dá outras providências. Disponível em: <http://www.planalto.gov.br/ccivil_03/_ato2004-2006/2004/lei/110.861.htm>. Acesso em: 15/08/2015.

Lei $\mathrm{n}^{\circ} 11.738$, de 16 de julho de 2008. Regulamenta a alínea "e" do inciso III do caput do art. 60 do Ato das Disposições Constitucionais Transitórias, para instituir o piso salarial profissional nacional para os profissionais do magistério público da educação básica. Não paginado. Disponível em: <http:// www.planalto.gov.br/ccivil_03/_ato2007-2010/2008/lei/111738.htm>. Acesso em: 31/01/2016.

Plano Nacional de Educação 2014-2014 [recurso eletrônico]: Lei $n^{\circ}$ 13.005, de 25 de junho de 2014, que aprova o Plano Nacional de Educação (PNE) e dá outras providências. $2^{\mathrm{a}}$ ed. Brasília: Câmara dos Deputados, Edições Câmara, 2015. Disponível em <http://bd.camara.leg.br/bd/bitstream/handle/bdcamara/ 20204/plano_nacional_educacao_2014-2024_2ed.pdf?sequence=13>. Acesso em: 29/01/2016.

BRZEZINSKI, Iria. Formação de profissionais da educação (2003-2010). Brasília: Instituto Nacional de Estudos e Pesquisas Educacionais Anísio Teixeira, 2014.

BRZEZINSKI, Iria; GARRIDO, Elsa. Análise dos trabalhos do GT Formação de Professores: o que revelam as pesquisas do período 1992-1998. Revista Brasileira de Educação, Rio de Janeiro, n. 18, p. 82-100, 2001.

BUENO AMBROSINI, Bianca. Aspectos da construção da identidade docente de professores de Ciências e Biologia, atuantes na rede pública estadual do município de Porto Alegre, egressos da UFRGS. 2012. 142f. Dissertação (Mestrado em Educação). Universidade Federal do Rio Grande do Sul, Porto Alegre, 2012.

CANCHERINI, Ângela. A socialização do professor iniciante: um difícil começo. Trabalho apresentado no II Congreso Internacional sobre profesorado principiante e inserción profesional a la docência. Buenos Aires, 2010. Disponível em: 
$<$ http://cedoc.infd.edu.ar/noveles/principiantes/2/INV_2_Cancherini_A_SOCIALI ZACAO_DO_PROFESSOR_INICIANTE.pdf>. Acesso em: 27/09/2014.

CANDAU, Vera Maria; LELIS, Isabel Alice. A relação teoria-prática na formação do educador. In: CANDAU, Vera Maria. (Org.). Rumo a uma nova Didática. $16^{\mathrm{a}}$ ed. Petrópolis: Editora Vozes, 2005. p. 56-72.

CHARTIER, Roger. A história cultural entre práticas e representações. Rio de Janeiro: Bertrand Brasil; Lisboa/Portugal: DIFEL, 1990.

CNE/CP. Resolução no 1 , de 15 de maio de 2006. Institui Diretrizes Curriculares Nacionais para o Curso de Graduação em Pedagogia, licenciatura. Disponível em: <http://portal.mec.gov.br/cne/arquivos/pdf/rcp01_06.pdf>. Acesso em: 03/11/2014.

CONTRERAS, José. A autonomia de professores. $2^{\mathrm{a}}$ ed. São Paulo: Cortez, 2012.

CORRÊA, Priscila Monteiro. Professores iniciantes e sua aprendizagem profissional no ciclo de alfabetização. 2015. 190f. Tese (Doutorado em Educação). Pontifícia Universidade Católica do Rio de Janeiro, Rio de Janeiro, 2015.

CORRÊA, Priscila Monteiro; PORTELLA, Vanessa Cristina Maximo. As pesquisas sobre professores iniciantes no Brasil: uma revisão. Olhar de Professor, Ponta Grossa, v. 15, n. 2, p. 223-236, 2012.

CORSI, Adriana Maria. Professoras iniciantes: situações difíceis enfrentadas no início da prática docente no ensino fundamental. Trabalho apresentado na $28^{\mathrm{a}}$ Reunião Anual da ANPEd. Caxambu, 2005. Disponível em: <http://28reuniao. anped.org.br/textos/gt08/gt0866int.rtf>. Acesso em:28/09/2014.

CUNHA, Maria Isabel da. Profissionalização docente: contradições e perspectivas. In: VEIGA, Ilma Passos Alencastro; CUNHA, Maria Isabel da. (Orgs.). Desmistificando a profissionalização do magistério. Campinas: Papirus Editora, 1999. p. 127-147.

DAMIANI, Magda Floriana. Entendendo o trabalho colaborativo em educação e revelando seus benefícios. Educar, Curitiba, n. 31, p. 213-230, 2008.

DAY, Christopher. Desenvolvimento profissional dos professores: os desafios da aprendizagem permanente. Porto/Portugal: Porto Ed., 2001.

DINIZ-PEREIRA, Júlio Emílio. O ovo ou a galinha: a crise da profissão docente e a aparente falta de perspectiva para a educação brasileira. Revista Brasileira de Estudos Pedagógicos, Brasília, v. 92, n. 230, p. 34-51, 2011.

DUBAR, Claude. A socialização. Construção das identidades sociais e profissionais. Porto/Portugal: Porto Ed., 1997.

FENEP. Números do ensino privado. 2013. Disponível em <http://www.fenep. org.br/wp-content/uploads/2014/08/Numeros-do-ensino-privado-20131.pdf>.

Acesso em: 31/01/2016.

FERREIRINHO, Viviane C. Práticas de socialização de professores iniciantes na carreira, quem é o iniciante? Trabalho apresentado na $28^{\mathrm{a}}$ Reunião Anual da ANPEd. Caxambu, 2005. Disponível em: <http://28reuniao.anped.org.br/ textos/gt14/gt141012int.doc>. Acesso em: 29/09/2014. 
FREIDSON, Eliot. Renascimento do Profissionalismo: teoria, profecia e política. São Paulo: Edusp, 1998.

FREITAS, Maria Nivalda de Carvalho. Organização escolar e socialização profissional de professores iniciantes. Cadernos de Pesquisa, São Paulo, n.115, p. 155-172, 2002.

O professor iniciante e suas estratégias de socialização profissional. 2000. 119f. Dissertação (Mestrado em Educação). Pontifícia Universidade Católica do Rio de Janeiro, Rio de Janeiro, 2000.

FURLAN, Elaine Gomes Matheus. Saberes docentes: a opinião dos professores iniciantes. Interciência \& Sociedade, Mogi Guaçu, vol. 3, n.2, p. 90-98, 2014.

Processos de socialização e construção de identidade profissional do professor iniciante de química. Trabalho apresentado no XVI ENDIPE - Encontro Nacional de Didática e Práticas de Ensino. UNICAMP, Campinas, p. 14-25, 2012. Disponível em: <http://www.infoteca.inf.br/endipe/smarty/templates/arquivos_ template/upload_arquivos/acervo/docs/3423c.pdf>. Acesso em: 28/09/2014.

$O$ processo de socialização e construção de identidade profissional do professor iniciante de Química. Tese (Doutorado em Educação: História, Política, Sociedade). Pontifícia Universidade Católica de São Paulo, São Paulo, 2011.

GATTI, Bernardete. Formação de Professores no Brasil: Características e Problemas. Educação \& Sociedade, Campinas, v. 31, n. 13, p. 1355-1379, 2010.

Editora, 2002.

A construção da pesquisa em educação no Brasil. Brasília: Plano

Reconhecimento social e as políticas de carreira docente na educação básica. Cadernos de Pesquisa, São Paulo, v. 42, n.145, p. 88-111, 2012a.

O início da carreira docente no Brasil: formas de entrada, primeiras experiências profissionais e políticas educacionais. Trabalho apresentado no III Congreso Internacional sobre Professorado Principiante e Inserción Profesional a la Docencia, Santiago de Chile, 2012b. Não paginado. CD-ROM.

GIL, Antônio Carlos. Como elaborar projetos de pesquisa. $4^{a}$ ed. São Paulo: Atlas, 2002.

GUARNIERI, Maria Regina. O professor iniciante e o trabalho com as diferenças dos alunos. In: ANDRÉ, Marli. (Org.). Pedagogia das diferenças na sala de aula. $9^{a}$ ed. Campinas: Papirus Editora, 2008. p. 133-152.

GUIMARÃES, Valter Soares. A socialização profissional e profissionalização docente: um estudo baseado no professor recém-ingresso na profissão. In:

(Org.). Formar para o mercado ou para a autonomia? O papel da universidade. Campinas, Papirus Editora, 2006. p. 129-150.

HUBERMAN, Michael. O ciclo de vida profissional dos professores. In: NÓVOA, António. (Org.). Vidas de professores. Porto/Portugal: Porto Ed., 1992. p. 31-61.

INEP. Censo escolar da educação básica 2012 - resumo técnico. Brasília: Instituto Nacional de Estudos e Pesquisas Educacionais Anísio Teixeira/Ministério da Educação, 2013. Disponível em: <http://download.inep. 
gov.br/educacao_basica/censo_escolar/resumos_tecnicos/resumo_tecnico_censo_ educacao_basica_2012.pdf>. Acesso em: 04/11/2014.

KARABEL, Jerome; HALSEY, A. H. Educational Research: A Review and an Interpretation. In:

Power and Ideology in Education. New York: Oxford University Press, 1997. Introdução, p. 1-85.

LACERDA, Patrícia Monteiro. A vingança dos anexos ou como a elaboração de um questionário tornou-se, ela mesma, uma pesquisa. 2000. $106 f$. Dissertação (Mestrado em Educação). Pontifícia Universidade Católica do Rio de Janeiro, Rio de Janeiro, 2000.

LELIS, Isabel Alice Oswald Monteiro. A polissemia do magistério: entre mitos e histórias. 1996. 224f. Tese (Doutorado em Educação). Pontifícia Universidade Católica do Rio de Janeiro, Rio de Janeiro, 1996.

LIBÂNEO, José Carlos. O dualismo perverso da escola pública brasileira: escola do conhecimento para os ricos, escola do acolhimento social para os pobres. Educação e Pesquisa, São Paulo, v. 38, n. 1, p. 13-28, 2012.

LIMA, Emília Freitas. A construção do início da docência: reflexões a partir de pesquisas brasileiras. Revista do Centro de Educação, Santa Maria, v. 29, n.2, p. 85-98, 2004.

LORTIE, Dan C. School-teacher: a sociological study. Chicago/Estados Unidos: The University of Chicago Press, 1975.

LÜDKE, Menga. O educador: um profissional? In: CANDAU, Vera Maria. (Org.). Rumo a uma nova Didática. $16^{\mathrm{a}}$ ed. Petrópolis: Editora Vozes, 2005. p. 73-85.

Sobre a socialização profissional de professores. Cadernos de Pesquisa, São Paulo, n.99, p. 5-15, 1996.

LÜDKE, Menga; BOING, Luiz Alberto. Caminhos da profissão e da profissionalidade docentes. Educação \& Sociedade, Campinas, v. 25, n. 89, p. 1159-1180, 2004.

Profissionalidade docente. (verbete) In: OLIVEIRA, Dalila Andrade; DUARTE, Adriana Cancella; VIEIRA, Lívia Fraga. (Orgs.). Dicionário: Trabalho, profissão e condição docente. Belo Horizonte, UFMG, 2010. Não paginado. Disponível em: <http://trabalhodocente.net.br/?pg= dicionarioverbetes\&id=345>. Acesso em 12/08/2015.

Do trabalho à formação de professores. Cadernos de Pesquisa, São Paulo, v. 42, n. 146, p. 428-451, 2012.

MACIENTE, Aguinaldo Nogueira. et al. A inserção de recém-graduados em engenharias, medicina e licenciaturas no mercado de trabalho formal. Radar: tecnologia, produção e comércio exterior. Instituto de Pesquisa Econômica Aplicada. Brasília, n. 38, p, 7-22, abril/2015. Disponível em: <http://www.ipea. gov.br/portal/images/stories/PDFs/radar/150504_radar_38.pdf >. Acesso em: 29/01/2016.

MARCELO, Carlos. Desenvolvimento profissional docente: passado e futuro. Sísifo. Revista de Ciências da Educação, Lisboa/Portugal, n. 8, p. 7-22, 2009. Disponível em: < http://www.unitau.br/files/arquivos/category_1/MARCELO_ 
Desenvolvimento_Profissional_Docente_passado_e_futuro_1386180263.pdf>. Acesso em 28/06/2015.

MARCELO GARCÍA, Carlos. A formação de professores: novas perspectivas baseadas na investigação sobre o pensamento do professor. In: NÓVOA, António. Os professores e a sua formação. (Coord.). $2^{\mathrm{a}}$ ed. Lisboa/Portugal: Publicações Dom Quixote, 1995. p. 51-76.

MARIANO, André Luiz Sena. A pesquisa sobre o professor iniciante e o processo de aprendizagem profissional: algumas características. Trabalho apresentado na 29 $9^{a}$ Reunião Anual da ANPEd. Caxambu, 2006. Disponível em: <http://29reuniao.anped.org.br/trabalhos/posteres/GT08-2119--Int.pdf>. Acesso em: 29/07/2014.

MARIN, Alda Junqueira. O trabalho docente: núcleo de perspectiva globalizadora de estudos sobre ensino. In: (Coord.). Didática e trabalho docente. Araraquara: JM, 1996. p. 23-43.

Precarização do trabalho docente. (verbete) In: OLIVEIRA, Dalila Andrade; DUARTE, Adriana Cancella; VIEIRA, Lívia Fraga. (Orgs.). Dicionário: Trabalho, profissão e condição docente. Belo Horizonte, UFMG, 2010. Não paginado. Disponível em: <http://trabalhodocente. net.br/?pg=dicionario-verbetes\&id=331>. Acesso em 23/02/2016.

MAY, Tim. Pesquisa social: questões, métodos e processos. $3^{\mathrm{a}}$ ed. Porto Alegre: Artmed, 2004.

MEIRA, Maria Dyrce Dias; KURCGANT, Paulina. Avaliação de curso de graduação segundo egressos. Revista da Escola de Enfermagem da USP, São Paulo, v. 43, n.2, p. 481-485, 2009.

MELLO, Guiomar Namo de. Formação inicial de professores para a educação básica: uma (re)visão radical. São Paulo em Perspectiva, São Paulo, v. 14, n. 1, p. $98-110,2000$.

MORGADO, José Carlos. Identidade e profissionalidade docente: sentidos e (im)possibilidades. Ensaio: Avaliação e Políticas Públicas em Educação, Rio de Janeiro, vol. 19, n.73, p. 793-812, 2011.

MOURA, Heloísa Tavares de. O professor iniciante: o período inicial da carreira do professor de $1^{\mathrm{a}}$ a $4^{\mathrm{a}}$ série do ensino fundamental na cidade do Rio de Janeiro. 1998. 281f. Dissertação (Mestrado em Educação). Universidade do Estado do Rio de Janeiro, Rio de Janeiro, 1998.

NASCIMENTO, Maria das Graças C. de Arruda. O trabalho docente no início da carreira: implicações para a formação profissional. Trabalho apresentado no XVI ENDIPE - Encontro Nacional de Didática e Práticas de Ensino. UNICAMP, Campinas, p. 14-25, 2012. Disponível em: < http://www.infoteca.inf.br/endipe/ smarty/templates/arquivos_template/upload_arquivos/acervo/docs/1524d.pdf >.

Acesso em: 13/01/2016.

NEGRI, Fernanda de; SILVA, Carolina Andrade. A evolução do emprego qualificado no Brasil entre 2008 e 2013. Radar: tecnologia, produção e comércio exterior. Instituto de Pesquisa Econômica Aplicada. Brasília, n. 38, p, 23-28, abril/2015. Disponível em: <http://www.ipea.gov.br/portal/images/stories/ PDFs/radar/150504_radar_38.pdf>. Acesso em: 29/01/2016. 
NERI, Marcelo. Escolhas universitárias e performance trabalhista. Radar: tecnologia, produção e comércio exterior. Instituto de Pesquisa Econômica Aplicada. Brasília, n. 27, p, 7-20, julho/2013. Disponível em: <http://www.ipea. gov.br/portal/images/stories/PDFs/radar/130703_radar27.pdf $>$. Acesso em: 29/01/2016.

NETO, Samuel de Souza; BENITES, Larissa Cerignoni; SILVA, Mellissa Fernanda Gomes da. Da escola de ofício a profissão educação física: a constituição do habitus profissional de professor. Motriz: Revista da Educação Física. Rio Claro, vol. 16, n.4, p. 1033-1044, 2010.

NETO, Samuel de Souza; SARTI, Flávia Medeiros; BENITES, Larissa Cerignoni. Do ofício de aluno ao habitus profissional docente: desafios do estágio supervisionado. Trabalhando na IX Reunião Anual da ANPEd Sul. Caxias do Sul, 2012. Não paginado. Disponível em: < http://www.fe.ufrj.br/anpedinha2011/ trabalhos/PPGE_015.182.018-06_trabalho.pdf>. Acesso em: 11/02/2016.

NONO, Maévi Anabel; MIZUKAMI, Maria da Graça Nicoletti. Processos de formação de professoras iniciantes. Trabalho apresentado na $29^{a}$ Reunião Anual da ANPEd. Caxambu, 2006. Disponível em: <http://29reuniao.anped.org.br/ trabalhos/trabalho/GT08-1868--Int.pdf> . Acesso em: 28/09/2014.

NÓVOA, António. Os professores e a sua formação. (Coord.). $2^{\mathrm{a}}$ ed. Lisboa/Portugal: Publicações Dom Quixote, 1995.

. (Org.). Profissão Professor. Porto/Portugal: Porto Ed., 1999.

. (Org.). Vidas de professores. Porto/Portugal: Porto Ed., 1992.

OLIVEIRA, Romualdo Portela de. Da universalização do ensino fundamental ao desafio da qualidade: uma análise histórica. Educação \& Sociedade, Campinas, v. 28, n. 100, p. 661-690, 2007.

OLIVEIRA, Dalila Andrade. Trabalho docente (verbete) In: OLIVEIRA, Dalila Andrade; DUARTE, Adriana Cancella; VIEIRA, Lívia Fraga. (Orgs.). Dicionário: Trabalho, profissão e condição docente. Belo Horizonte, UFMG, 2010. Não paginado. Disponível em: <http://trabalhodocente. net.br/?pg=dicionario-verbetes\&id=429> . Acesso em 02/02/2015.

OLIVERIO, Vanessa Cristina Maximo Portella. Professores iniciantes: inserção nas redes de ensino e condições de trabalho desiguais. 2014. 263f. Tese (Doutorado em Educação). Pontifícia Universidade Católica do Rio de Janeiro, Rio de Janeiro, 2014.

PAPI, Silmara de Oliveira Gomes. Os desafios vivenciados por professoras iniciantes em seu processo de desenvolvimento profissional. Trabalho apresentado no III Congreso Internacional sobre Professorado Principiante e Inserción Profesional a la Docencia, Santiago de Chile, 2012. Não paginado. CD-ROM.

Professores iniciantes bem-sucedidas: um estudo sobre seu desenvolvimento profissional. 2011a. 300f. Tese (Doutorado em Educação). Pontifícia Universidade Católica do Paraná, Curitiba, 2011a.

Professoras iniciantes bem-sucedidas: elementos de seu desenvolvimento profissional. Trabalho apresentado na $34^{\text {a }}$ Reunião Anual da ANPEd. Natal, 2011b. Não paginado. Disponível em: <http://34reuniao.anped.org.br/images/ trabalhos/GT08/GT08-695\%20int.pdf>. Acesso em: 16/09/2014. 
PAPI, Silmara de Oliveira Gomes; MARTINS, Pura Lúcia Oliver. As pesquisas sobre professores iniciantes: algumas aproximações. Educação em Revista, Belo Horizonte, v. 26, n.3, p. 39-56, 2010.

PERRENOUD, Phillipe. et al. (Orgs.). Formando Professores Profissionais: Quais estratégias? Quais competências? 2a ed. rev. Porto Alegre: Artmed, 2001.

PIMENTA, Selma Garrido. Pesquisa e formação de professores: Contextualização histórica e epistemológica de um projeto integrado. In: GUIMARÃES, Valter Soares. (Org.). Formar para o mercado ou para a autonomia? O papel da universidade. Campinas, Papirus Editora, 2006. p. 67-87.

PITA, Tatiana de Jesus. Destino social de alguns egressos do curso de Pedagogia de uma Instituição de Ensino Superior privada com baixa avaliação no Ministério da Educação. 2011. 83f. Dissertação (Mestrado em Educação: História, Política, Sociedade). Pontifícia Universidade Católica de São Paulo, São Paulo, 2011.

POPKEWITZ, Thomas S. Profissionalização e formação de professores: algumas notas sobre a sua história, ideologia e potencial. In: NÓVOA, Antonio. Os professores e a sua formação. (Coord.). $2^{\mathrm{a}}$ ed. Lisboa/Portugal: Publicações Dom Quixote, 1995. p. 35-50.

REIS, Anna Carolina de Lazzari. Representações sociais sobre o ser professor: indícios da constituição da identidade docente. 2011. 93f. Dissertação (Magister Scientiae). Universidade Federal de Viçosa, Viçosa, 2011.

ROLDÃO, Maria do Céu Neves. Profissionalidade docente em análise especificidades dos ensinos superior e não superior. Nuances: estudos sobre educação, Presidente Prudente, ano XI, vol. 12, n. 13, p. 105-126, 2005.

SARTI, Flávia Medeiros. O triângulo da formação docente: seus jogadores e configurações. Educação e Pesquisa, São Paulo, vol. 38, n.2, p. 323-338, 2012.

SAVIANI, Dermeval. Formação de professores: aspectos históricos e teóricos do problema no contexto brasileiro. Revista Brasileira de Educação, Rio de Janeiro, v. 14, n. 40, 143-155, 2009.

SCHÖN, Donald A. Formar professores como profissionais reflexivos. In: NÓVOA, Antonio. Os professores e a sua formação. (Coord.). $2^{\mathrm{a}}$ ed. Lisboa/Portugal: Publicações Dom Quixote, 1995. p. 77-92.

SELLTIZ, Claire; JAHODA, Marie; DUTSCH, Morton; COOK, Stuart W. Métodos de pesquisa nas relações sociais. $6^{\mathrm{a}}$ reimpressão. São Paulo: EPU, Ed. USP, 1975.

SETTON, Maria da Graça Jacintho. A socialização como fato social total: notas introdutórias sobre a teoria do habitus. Revista Brasileira de Educação, Rio de Janeiro, vol. 14, n.41, p. 296-307, 2009.

A teoria do habitus em Pierre Bourdieu: uma leitura contemporânea. Revista Brasileira de Educação, Rio de Janeiro, n.20, p. 60-70, 2002.

SILVA, Marilda da. Habitus professoral e habitus estudantil: uma proposição acerca da formação de professores. Educação em Revista, Belo Horizonte, v. 27, n. 03, p. 335-360, 2011. 
SILVA, Vandré Gomes da; ALMEIDA, Patrícia Cristina Albieri de. (Coord.). Ação docente e profissionalização: referentes e critérios para formação. Textos FCC, São Paulo, v. 44, p. 1-112, 2015.

SILVA; Eliane Paganini da; CHAKUR, Cilene Ribeiro de Sá Leite. A Tomada de Consciência da Crise de Identidade Profissional em Professores do Ensino Fundamental. Schème - Revista Eletrônica de Psicologia e Epistemologia Genéticas, Marília, v. 2, n. 3, p. 221-241 2009. Disponível em: <http://www2. marilia.unesp.br/revistas/index.php/scheme/article/view/581/465>. Acesso em 21/02/2016.

SHIROMA, Eneida Oto. Implicações da política de profissionalização sobre a gestão e o trabalho docente. Trabalho \& Educação, Belo Horizonte, v. 13, n. 2, p. 113-125, 2004.

SHIROMA, Eneida Oto; EVANGELISTA, Olinda. Profissionalização docente. (verbete) In: OLIVEIRA, Dalila Andrade; DUARTE, Adriana Cancella; VIEIRA, Lívia Fraga. (Orgs.). Dicionário: Trabalho, profissão e condição docente. Belo Horizonte, UFMG, 2010. Não paginado. Disponível em: <http://trabalhodocente. net.br/?pg=dicionario-verbetes\&id=346> . Acesso em 12/08/2015.

SOUTO, Romélia Mara Alves; PAIVA, Paulo Henrique Apipe Avelar de. A pouca atratividade da carreira docente: um estudo sobre o exercício da profissão entre egressos de uma Licenciatura em Matemática. Pró-Posições, Campinas, vol. 24, n.1, p. 201-224, 2013.

TARDIF, Maurice. Os saberes dos professores. (verbete) In: OLIVEIRA, Dalila Andrade; DUARTE, Adriana Cancella; VIEIRA, Lívia Fraga. (Orgs.). Dicionário: Trabalho, profissão e condição docente. Belo Horizonte, UFMG, 2010. Não paginado. Disponível em 2010. Disponível em: <http://www.trabalho docente.net.br/?pg=dicionario-verbetes\&id=308>. Acesso em 17/01/2016.

Saberes docentes e formação profissional. Petrópolis: Vozes, 2002.

TOWNSEND, Cristina Bandeira; TOMAZZETI, Elisete Medianeira. A mobilização de saberes nas práticas de professores nos anos iniciais: um estudo de caso. Educar, Curitiba, n. 29, p. 207-221, 2007.

UNESCO. O perfil dos professores brasileiros: o que fazem, o que pensam, o que almejam. São Paulo: Moderna, 2004.

Professores do Brasil: impasses e desafios. / Coordenado por Bernadete Angelina Gatti e Elba Siqueira de Sá Barreto. Brasília: UNESCO, 2009.

VALLE, Ione Ribeiro. Carreira do magistério: uma escolha profissional deliberada? Revista Brasileira de Estudos Pedagógicos, Brasília, v. 87, n. 216, p. 176-187, 2006.

VARGAS, Hustana Maria. Formação docente, profissão docente e qualidade da educação: laços a restabelecer. In: XAVIER, Alice; CANEDO, Maria Luiza; BRANDÃO, Zaia. (Orgs.). Construção da qualidade de ensino: Achados e tensões de uma década de pesquisas. Rio de Janeiro: Forma \& Ação Editora, 2013. p. 231-253.

VEENMAN, Simon. Perceived problems of beginning teachers. Review of Educational Research, v. 54, n. 2, p. 143-178, 1984. 
WEBER, Max. Economia e Sociedade: Fundamentos da sociologia

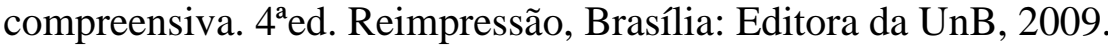

WZOREK, Rodrigo Marcelo. Percepções dos professores das disciplinas específicas frente à carreira docente. 2009. 166f. Dissertação (Mestrado em Educação). Universidade do Vale do Itajaí, Itajaí, 2009.

XAVIER, Alice; CANEDO, Maria Luiza; BRANDÃO, Zaia. (Orgs.). Construção da qualidade de ensino: Achados e tensões de uma década de pesquisas. Rio de Janeiro: Forma \& Ação Editora, 2013. 


\section{7 \\ Apêndices}

\section{Termo de Consentimento Livre e Esclarecido}

Pesquisa: "Profissionalidade e identidade docente de professores iniciantes: um estudo com os egressos dos cursos de licenciatura em Ciências Biológicas e em Pedagogia"

O questionário a seguir faz parte da pesquisa desenvolvida por Rômulo Loureiro Casciano, no âmbito do curso de Mestrado em Educação da PUC-Rio, sob a orientação da $\operatorname{Prof}^{\mathrm{a}} \operatorname{Dr}^{\mathrm{a}}$ Zaia Brandão. O tema da pesquisa é a construção da profissionalidade docente no início da carreira de professores da educação básica, egressos dos cursos de Ciências Biológicas e Pedagogia.

A investigação objetiva conhecer como os professores iniciantes entram no mercado de trabalho e quais as características que atribuem para a profissão a partir de sua formação inicial e das experiências/vivências ao longo dos primeiros anos de magistério. Espera-se compreender sobre o momento de entrada na profissão a fim de contribuir com a valorização da profissão docente, com os processos formativos e as práticas pedagógicas dos professores da Educação Básica.

A participação na pesquisa é voluntária e não oferece qualquer risco moral, uma vez que a identidade daqueles que fornecerem as informações através do preenchimento e envio do questionário será mantida em sigilo. Além disso, a participação é isenta de despesas e tomará cerca de 30 minutos para ser efetivada. Os resultados serão publicados estritamente em contextos acadêmicos, na ocasião do término da pesquisa. Aqueles que tiverem interesse em ler o trabalho final podem entrar em contato através do e-mail ou telefone. A participação na pesquisa pode ser interrompida a qualquer momento, sem aplicação de qualquer penalidade ou constrangimento.

O consentimento fundamenta-se na garantia do respeito à dignidade humana e aos princípios éticos em pesquisa e na disponibilização, pelo pesquisador responsável, desses esclarecimentos iniciais, bem como outros que por ventura venham a ser feitos pelo participante.

O recebimento do questionário respondido será entendido como a concordância do participante e seu entendimento livre e esclarecido sobre essa pesquisa.

Agradeço sua participação e contribuição para a pesquisa.

Rômulo Loureiro Casciano rlcasciano@yahoo.com.br 21-996399699

Zaia Brandão

zaiapucrio@gmail.com

21-35271815

* Caso concorde em participar e esteja ciente das informações acima, selecione a caixa "Concordo" abaixo e depois clique em "Avançar" para iniciar o questionário. Estas mesmas informações serão apresentadas ao final da série de perguntas.

\section{Concordo.}




\section{Questionário Professores Iniciantes}

* Qual é o seu sexo?

O Feminino

O Masculino

* Qual é a data do seu nascimento? (informe dia/mês/ano em números)

* Qual é o nível de escolaridade de sua mãe?

O Nenhum

O Ensino Fundamental incompleto

O Ensino Fundamental completo

O Ensino Médio incompleto

O Ensino Médio completo

O Ensino Superior incompleto

O Ensino Superior completo

O Pós-Graduação

O Não sei.

* Qual é o nível de escolaridade de seu pai?

O Nenhum

O Ensino Fundamental incompleto

O Ensino Fundamental completo

O Ensino Médio incompleto

O Ensino Médio completo

O Ensino Superior incompleto

O Ensino Superior completo

O Pós-Graduação

O Não sei.

* Qual foi o curso de Ensino Médio que você concluiu?

O Regular

O Magistério ou Normal

O Técnico/Profissionalizante

O Educação de Jovens e Adultos/Supletivo

* Qual foi o curso de graduação que você concluiu?

O Licenciatura em Pedagogia

O Licenciatura em Ciências Biológicas

Caso tenha feito ou esteja fazendo outra graduação, diga qual curso e quando (especifique)

* Qual foi o ano de entrada no curso de graduação? 
* Qual foi o ano de conclusão no curso de graduação?

* $O$ curso de graduação que você realizou foi sua primeira opção?

O Sim

O Não

* Qual curso foi a sua primeira opção?

* Antes de começar o curso de graduação você teve alguma experiência como professor? O Sim

O Não

* Como foi essa atuação como professor antes de entrar no curso de graduação? (Responda em até 150 caracteres.)

* Usando uma escala de "nada importante" a "muito importante", indique as motivações para escolha do curso de licenciatura que você realizou.

\begin{tabular}{|c|c|c|c|c|}
\hline & $\begin{array}{c}\text { Nada } \\
\text { importante }\end{array}$ & $\begin{array}{l}\text { Pouco } \\
\text { importante }\end{array}$ & Importante & $\begin{array}{c}\text { Muito } \\
\text { importante }\end{array}$ \\
\hline Alcançar estabilidade profissional. & O & 0 & O & O \\
\hline $\begin{array}{l}\text { Aumentar a renda em relação à minha origem } \\
\text { familiar. }\end{array}$ & O & O & O & O \\
\hline $\begin{array}{l}\text { Alcançar melhor status em relação à minha origem } \\
\text { familiar. }\end{array}$ & O & O & O & O \\
\hline Contribuir para o meu desenvolvimento intelectual. & O & O & O & O \\
\hline $\begin{array}{l}\text { Identificação com o exemplo/Admiração por antigo } \\
\text { professor. }\end{array}$ & O & O & O & O \\
\hline $\begin{array}{l}\text { Influência da família/amigos para essa área de } \\
\text { atuação. }\end{array}$ & O & O & ○ & O \\
\hline Menor relação candidato/vaga. & O & O & O & O \\
\hline Obter diploma de curso superior. & O & O & O & O \\
\hline $\begin{array}{l}\text { Ter o magistério como outra opção profissional, } \\
\text { porém não a primeira. }\end{array}$ & O & O & ○ & O \\
\hline Vontade de trabalhar como professor. & O & O & O & O \\
\hline Vocação. & O & O & O & O \\
\hline Outro (especifique) & & & & \\
\hline
\end{tabular}

* Ao longo do curso de graduação, você teve experiência com... (você pode marcar mais de uma resposta)

$\square$ Projeto de extensão

Projeto de pesquisa

Projeto de estímulo à docência.

Monitoria de disciplinas na graduação.

$\checkmark$ Monitoria na educação básica.

$\square$ Nenhuma das anteriores. 


\begin{tabular}{|c|c|c|c|c|}
\hline & $\begin{array}{l}\text { Nada } \\
\text { relevante }\end{array}$ & $\begin{array}{l}\text { Pouco } \\
\text { relevante }\end{array}$ & Relevante & $\begin{array}{l}\text { Muito } \\
\text { relevante }\end{array}$ \\
\hline $\begin{array}{l}\text { Fundamentos da Educação (História, Psicologia, } \\
\text { Filosofia, Sociologia) }\end{array}$ & 0 & 0 & 0 & 0 \\
\hline Didáticas/Metodologias de Ensino & 0 & 0 & 0 & 0 \\
\hline Estágios/Práticas de Ensino & 0 & O & 0 & 0 \\
\hline Demais disciplinas de formação específica & 0 & 0 & 0 & 0 \\
\hline
\end{tabular}
Outro (especifique)

\section{* Analise as frases a seguir e indique o seu nível de concordância ou discordância.}

\begin{tabular}{|c|c|c|c|c|}
\hline & $\begin{array}{l}\text { Discordo } \\
\text { totalmente }\end{array}$ & $\begin{array}{c}\text { Discordo } \\
\text { parcialmente }\end{array}$ & $\begin{array}{l}\text { Concordo } \\
\text { parcialmente }\end{array}$ & $\begin{array}{l}\text { Concordo } \\
\text { totalmente }\end{array}$ \\
\hline $\begin{array}{l}\text { Ao entrar no curso de graduação já possuía a } \\
\text { vontade de trabalhar como professor. }\end{array}$ & 0 & 0 & 0 & 0 \\
\hline $\begin{array}{l}\text { Ao final do curso possuía a vontade de trabalhar } \\
\text { como professor. }\end{array}$ & 0 & 0 & 0 & 0 \\
\hline $\begin{array}{l}\text { Ao longo do curso havia discussões sobre o } \\
\text { trabalho do professor. }\end{array}$ & 0 & 0 & 0 & 0 \\
\hline $\begin{array}{l}\text { O conteúdo das disciplinas de graduação era } \\
\text { trabalhado de forma a contribuir para a prática } \\
\text { docente. }\end{array}$ & 0 & O & 0 & 0 \\
\hline $\begin{array}{l}\text { O conteúdo das disciplinas de graduação abrange } \\
\text { o conteúdo dos conhecimentos curriculares } \\
\text { escolares. }\end{array}$ & 0 & 0 & O & 0 \\
\hline $\begin{array}{l}\text { A formação inicial (licenciatura) dialoga com os } \\
\text { diversos contextos de trabalho dos professores. }\end{array}$ & 0 & 0 & 0 & 0 \\
\hline $\begin{array}{l}\text { Acredito que o curso de graduação desenvolveu } \\
\text { um conjunto de competências e saberes que irão } \\
\text { facilitar minha atuação como professor. }\end{array}$ & 0 & 0 & 0 & 0 \\
\hline $\begin{array}{l}\text { A formação pedagógica recebida no meu curso foi } \\
\text { essencial para a minha atuação docente. }\end{array}$ & 0 & 0 & 0 & 0 \\
\hline $\begin{array}{l}\text { A formação pedagógica recebida no meu curso foi } \\
\text { suficiente para a minha atuação docente. }\end{array}$ & 0 & 0 & O & 0 \\
\hline $\begin{array}{l}\text { Lidar com os alunos e saber realizar } \\
\text { procedimentos e } \\
\text { pedagógicas como professor são abordados }\end{array}$ & 0 & 0 & 0 & 0 \\
\hline
\end{tabular}
abordados ao longo do curso de licenciatura.

Há um bom equilíbrio entre discussões teóricas e abordagens práticas dos conteúdos durante a formação inicial.

A realização de um curso de licenciatura e a atuação como professor da educação básica conferem um aumento de prestígio social e realização profissional.

Licenciados para atuar como professores de séries iniciais, professores de séries finais do ensino fundamental e professores do ensino médio desenvolvem a mesma carga de trabalho.

Professores nestes três níveis de ensino alcançam o mesmo nível de reconhecimento e prestígio social.

$\begin{array}{llll}0 & 0 & 0\end{array}$

$\begin{array}{llll}0 & 0 & 0\end{array}$


* Ao concluir o curso de graduação você iniciou de imediato em um emprego como professor?

O Sim

O Não

* Considerando a questão anterior, você está: (é possível marcar mais de uma opção de resposta)

Desempregado.

$\square$ Trabalhando como professor.

Trabalhando na área de educação, mas não como professor.

$\checkmark$ Trabalhando fora da área de educação.

$\square$ Realizando outro curso de graduação.

$\square$ Realizando curso de especialização/pós-graduação.

Procurando inserção profissional como professor.

Procurando outros empregos.

Considerando sua resposta anterior, especifique dizendo qual o outro curso de graduação, especialização ou pós-graduação você está fazendo, ou que outro emprego (fora da área de educação) você está procurando ou trabalhando no momento.

(Deixe em branco se respondeu que está desempregado ou trabalhando como professor.)

* As próximas perguntas estão direcionadas ao trabalho como professor. Caso você tenha exercido a profissão por algum tempo ou esteja atuando no magistério selecione 'Continuar'. Se você não atuou no magistério, selecione 'Encerrar'.

O Continuar.

O Encerrar.

* Como foi sua inserção profissional como professor?

O Indicação.

O Submissão de currículo.

O Concurso público.

O Contrato temporário.

O Outro (especifique)

* Quando tempo depois de concluir o curso de graduação você conseguiu seu primeiro emprego como professor?

O Antes de concluir.

O Menos de seis meses depois.

O De seis meses a um ano depois.

O De um a dois anos depois.

O Mais de dois anos depois. 
* Há quanto tempo você trabalha como professor?

O Até um ano.

O Entre um e três anos.

O De três a seis anos.

O Mais de seis anos.

* Em qual tipo de estabelecimento você trabalha como professor? Se trabalhar em mais de um tipo, marque aqueles que correspondem aos seus empregos.

$\square$ Particular preparatório/Cursinho

$\square$ Particular ensino regular

Público municipal

Público estadual

Público federal

$\square$ Outro (especifique)

* Em qual nível de ensino você atua como professor? Se trabalha com mais de um nível, marque aqueles que correspondem aos seus empregos.

$\square$ Educação Infantil

$\square$ Ensino Fundamental I ( $1^{\circ}$ ao $5^{\circ}$ anos)

$\square$ Ensino Fundamental II (6음 ao $9^{\circ}$ anos)

$\square$ Ensino Médio

$\square$ Educação de Jovens e Adultos

$\square$ Outro (especifique)

* Quantos empregos/matrículas você possui como professor? (Responda em até 50 caracteres.)

* Quantas horas por semana você trabalha como professor? (Responda em até 50 caracteres.)

* Quantas horas por semana em média você dedica ao seu trabalho como professor em casa? (Responda em até 50 caracteres.)

* Qual sua renda mensal como professor? (Responda em até 50 caracteres.)

* Além de trabalhar como professor você possui outra atividade remunerada?

O Sim

O Não 
Considerando sua resposta anterior, qual sua outra atividade remunerada? Diga também o rendimento mensal médio desta atividade. (Responda em até 100 caracteres.)

(Deixe em branco se respondeu 'Não' à pergunta anterior.)

* Qual sua principal fonte de rendimentos?

O Magistério

O Outra (especifique)

* Além de trabalhar como professor você realiza algum curso de formação continuada ou de qualificação profissional?
O Sim
O Não

* Especifique qual curso de formação continuada ou de qualificação profissional você está realizando.

* Abaixo estão algumas das motivações que levam os profissionais os professores a realizar um curso de formação continuada ou de qualificação profissional. Analise e indique sua concordância para cada item.

$$
\begin{array}{cccc}
\text { Discordo } & \text { Discordo } & \begin{array}{c}
\text { Concordo } \\
\text { totalmente }
\end{array} & \begin{array}{c}
\text { Concordo } \\
\text { parcialmente } \\
\text { parcialmente }
\end{array} \\
\text { totalmente }
\end{array}
$$

Aquisição de conhecimentos para buscar outras opções profissionais que não seja como regente de turma.

Aquisição de conhecimentos para o trabalho atual como professor da educação básica.

Aumento de salário/Progressão na carreira.

Desenvolvimento intelectual.

○

$0 \quad 0$

O

○

Intenção de atuar como professor do nível

superior.

$0 \quad 0 \quad 0 \quad 0$

Gostaria de mencionar outra razão que o estimulou a fazer esse curso? (Responda em até 200 caracteres.)

* Você já tentou abandonar a carreira docente?

O Sim

O Não

* Você continua trabalhando como professor?

O Sim

O Não 
* A seguir estão os principais motivos alegados por ex-professores, para justificar sua saída do magistério. Indique o quanto cada item apresentado está de acordo os motivos que levaram você a deixar o magistério.

Discordo parcialmente

Concordo

Concordo totalmente

0

parcialmente

totalmente

Baixo salário.

Desvalorização social.

0

$\mathrm{O}$

Estresse/problemas de saúde.

Insatisfação com a carreira.

0

0

0

Longa jornada de trabalho.

Melhor oportunidade financeira em outro emprego.

$\mathrm{O}$

0

0

O 0

O 0

Outro (especifique)

* A seguir estão algumas características para o magistério/docência como atividade profissional. Indique sua concordância para cada item.

\begin{tabular}{|lcccc} 
& $\begin{array}{c}\text { Discordo } \\
\text { totalmente }\end{array}$ & $\begin{array}{c}\text { Discordo } \\
\text { parcialmente }\end{array}$ & $\begin{array}{c}\text { Concordo } \\
\text { parcialmente }\end{array}$ & $\begin{array}{c}\text { Concordo } \\
\text { totalmente }\end{array}$ \\
\hline Autonomia (pedagógica). & 0 & 0 & 0 & 0 \\
\hline Conjunto de saberes específicos. & 0 & 0 & 0 & 0 \\
\hline Definição das atribuições/tarefas (laborais) do cargo. & 0 & 0 & 0 & 0 \\
\hline Exigência do curso de licenciatura. & 0 & 0 & 0 & 0 \\
\hline Gostar de crianças/adolescentes. & 0 & 0 & 0 & 0 \\
\hline Prestação de serviço. & 0 & 0 & 0 & 0 \\
\hline Representação por órgão de classe (exemplo: & 0 & 0 & 0 & 0 \\
\hline sindicato) ou pertencimento a outro coletivo. & & & 0 & 0 \\
\hline
\end{tabular}
Outro (especifique) 
* A seguir estão listados itens e situações pertinentes ao envolvimento do professor com o seu trabalho. Indique a relevância de cada item de acordo com suas experiências de atuação como professor.

\begin{tabular}{|c|c|c|c|c|}
\hline & $\begin{array}{l}\text { Nada } \\
\text { relevante }\end{array}$ & $\begin{array}{l}\text { Pouco } \\
\text { relevante }\end{array}$ & Relevante & $\begin{array}{l}\text { Muito } \\
\text { relevante }\end{array}$ \\
\hline $\begin{array}{l}\text { Buscar formação continuada e qualificação } \\
\text { profissional. }\end{array}$ & 0 & 0 & 0 & 0 \\
\hline Diagnosticar as necessidades dos alunos. & O & O & O & O \\
\hline $\begin{array}{l}\text { Diálogo e parceria com a coordenação } \\
\text { pedagógica. }\end{array}$ & 0 & O & O & O \\
\hline Diálogo e parceria com a direção escolar. & O & O & O & O \\
\hline $\begin{array}{l}\text { Diálogo e parceria com outros professores da } \\
\text { escola. }\end{array}$ & O & O & 0 & O \\
\hline $\begin{array}{l}\text { Diálogo e parceria com outros professores de sua } \\
\text { área. }\end{array}$ & O & 0 & 0 & 0 \\
\hline Discutir o currículo das disciplinas. & O & O & O & O \\
\hline $\begin{array}{l}\text { Fornecimento de materiais e acesso a recursos de } \\
\text { ensino pela escola. }\end{array}$ & o & o & o & 0 \\
\hline $\begin{array}{l}\text { Saber lidar com as diferenças individuais dos } \\
\text { alunos. }\end{array}$ & 0 & O & O & 0 \\
\hline Saber lidar com o estresse. & O & O & O & O \\
\hline Saber lidar com tarefas burocrático-administrativas. & 0 & O & 0 & 0 \\
\hline Manter a disciplina dos alunos. & 0 & 0 & 0 & 0 \\
\hline Motivar os alunos. & 0 & 0 & 0 & 0 \\
\hline $\begin{array}{l}\text { Perceber e lutar pelos direitos do profissional } \\
\text { professor. }\end{array}$ & 0 & 0 & 0 & 0 \\
\hline Preparar as aulas. & 0 & O & 0 & 0 \\
\hline Preparar as avaliações. & O & O & O & O \\
\hline Refletir sobre a prática docente. & 0 & O & 0 & 0 \\
\hline $\begin{array}{l}\text { Refletir sobre as finalidades do processo de } \\
\text { ensino-aprendizagem. }\end{array}$ & O & O & O & O \\
\hline Relação com os responsáveis pelos alunos. & 0 & 0 & 0 & 0 \\
\hline Utilizar metodologias diversificadas de ensino. & 0 & 0 & o & o \\
\hline
\end{tabular}

* Ao iniciar o seu primeiro emprego como professor houve algum acolhimento da instituição, no sentido de orientar suas atividades, fornecer subsídios materiais ou técnicos?

Sim Não

Apresentação da equipe pedagógica.

Apresentação das dependências da escola.

$\begin{array}{ll}0 & 0 \\ 0 & 0\end{array}$

Circular ou documento informando os procedimentos burocráticos/ administrativos (preenchimento de diários, documentos, relatórios, etc.)

Escolha de turmas e horários.

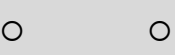

Fornecimento de materiais (giz, apagador, canetas, etc.), modelos de avaliações, livros, regimento, etc.

Orientação/Reunião/Projeto específico para receber professor iniciante.

Planejamento coletivo de atividades, calendário letivo, projetos, etc.

Reunião com os professores da área/Encontro com o grupo disciplinar.

$0 \quad 0$

Cite outro acolhimento ou procedimento de iniciação por parte da escola e dos colegas de trabalho. (Responda em até 200 caracteres.) 
As duas próximas questões são iguais no enunciado, mas diferem nas opções de resposta.

* Sinalize dentre os itens a seguir dois daqueles que descrevem os sentimentos mais fortes nos seus primeiros meses/anos de trabalho como professor da educação básica.

$\square$ Abandono/Solidão.

$\square$ Fazer parte de um coletivo de trabalho.

$\square$ Inseguro acerca dos conteúdos/métodos.

Não fui preparado para isso.

Preparado para lidar com as responsabilidades.

Reconhecimento.

Seguro acerca dos conteúdos/métodos.

$\square$ Nenhum dos anteriores

* Sinalize dentre os itens a seguir dois daqueles que descrevem os sentimentos mais fortes nos seus primeiros meses/anos de trabalho como professor da educação básica.

Choque de realidade.

Empolgado com as possibilidades.

$\square$ Indiferença.

$\square$ Medo.

Vontade de fazer o melhor.

Satisfação/Realização.

Outro (especifique)

* A seguir são apresentados argumentos para motivação do professor no desenvolvimento do seu trabalho. Indique a importância relativa para cada item usando a escala de "nada importante" a "muito importante".

Bom comportamento dos alunos.

Capacitação através da formação continuada.

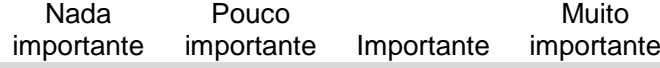
Infraestrutura e materiais de apoio na escola.

Reconhecimento da comunidade escolar. 0

Reconhecimento da sua família e de seus amigos. Salário e plano de carreira.

Troca de experiências com os colegas de trabalho.

O
O

0

0

0

O

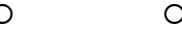

0

○

O

O

$0-0 \quad 0$

$\begin{array}{lll}0 & 0 & 0\end{array}$

0


* Qual a relevância que você atribui ao desempenho do professor com relação ...

\begin{tabular}{lcccc} 
& $\begin{array}{c}\text { Nada } \\
\text { relevante }\end{array}$ & $\begin{array}{c}\text { Pouco } \\
\text { relevante }\end{array}$ & $\begin{array}{c}\text { Muito } \\
\text { Relevante } \\
\text { relevante }\end{array}$ \\
$\begin{array}{l}\text { e docente. } \\
\text { Ao ambiente escolar: alunado, funcionários e corpo }\end{array}$ & 0 & 0 & 0 & 0 \\
$\begin{array}{l}\text { docente. } \\
\text { Ao comportamento dos alunos. }\end{array}$ & 0 & 0 & 0 & 0 \\
\hline $\begin{array}{l}\text { Ao envolvimento dos responsáveis. } \\
\text { Ao seu investimento/comprometimento pessoal. }\end{array}$ & 0 & 0 & 0 & 0 \\
$\begin{array}{l}\text { Aos investimentos da administração (pública ou } \\
\text { privada) na rede de ensino. }\end{array}$ & 0 & 0 & 0 & 0 \\
$\begin{array}{l}\text { Ao nível de exigência da gestão escolar/Depende } \\
\text { da instituição onde trabalha. }\end{array}$ & 0 & 0 & 0 & 0 \\
\hline
\end{tabular}

Outro (especifique)

* Indique a relação dos itens apresentados com sua prática docente nesses primeiros anos de trabalho. ( $O$ que Ihe ajudou e motivou a continuar o trabalho como professor?) Utilize a escala de "nada importante" a "muito importante".

\section{Aprendizado com as dificuldades do cotidiano.}

Nada Pouco Muito importante importante Importante importante Autonomia para planejar aulas, atividades e avaliações.

Conhecimentos adquiridos na formação inicial. O O O O Criatividade para elaborar materiais e estratégias de ensino-aprendizagem.

$0 \quad 0 \quad 0$

Dicas e sugestões aprendidos com os colegas de trabalho.

Domínio dos conteúdos curriculares.

O

O

O

\section{O}

$0 \quad 0$

$0 \quad 0$

o

$0 \quad 0$

O $\quad 0$

o

0

O $\quad 0$

Exemplos de professores quando você era o aluno.

O

O

O
Integração com outras disciplinas/áreas do conhecimento e/ou com o trabalho desenvolvido por outros professores da escola. Lembranças do tempo de aluno. Reconhecimento pelos professores mais experientes e pela equipe escolar.

O

0

Outro (especifique) 


\section{Obrigado pela sua contribuição!}

Você chegou ao final do questionário!

Como dito anteriormente, a participação na pesquisa é voluntária e não oferece qualquer risco moral, uma vez que a identidade daqueles que forneceram as informações através do preenchimento e envio do questionário será mantida em sigilo.

Os resultados serão publicados estritamente em contextos acadêmicos, na ocasião do término da pesquisa. Aqueles que tiverem interesse em ler o trabalho final ou quiserem esclarecer qualquer dúvida podem entrar em contato através do e-mail ou telefone abaixo.

Caso venhamos a realizar uma segunda etapa da pesquisa, através de uma entrevista, você estaria interessado em participar? Se estiver, solicito que envie uma mensagem para o e-mail (rlcasciano@yahoo.com.br) com seu nome, curso de licenciatura realizado e anos de magistério.

Agradecemos sua participação e contribuição para a pesquisa.

Rômulo Loureiro Casciano

rlcasciano@yahoo.com.br

21-996399699

Zaia Brandão

zaiapucrio@gmail.com

$21-35271815$ 